\title{
On the reconstruction of Proto-Mari vocalism*
}

Two different theories regarding the Proto-Mari vowel system have been put forward by Erkki Itkonen and Gábor Bereczki. This paper critically evaluates these theories and aims to establish a solidly argued reconstruction of Proto-Mari initial-syllable vocalism. It is argued that 11 distinct vowel phonemes must be reconstructed for Proto-Mari, as opposed to 13 reconstructed by Itkonen and 7 reconstructed by Bereczki.

Keywords: Uralic languages, Mari language, language reconstruction, historical phonetics.

\section{Introduction}

Two quite different theories regarding the Proto-Mari vowel system and the development of first-syllable vocalism in Mari varieties have been put forward by Itkonen (1954) and Bereczki (1994). The purpose of this paper is to critically evaluate these theories and to establish a solidly argued reconstruction of Proto-Mari vocalism. The older research history of Mari historical vocalism is reviewed by Itkonen (1954) and will not be discussed here.

Itkonen (1954) postulates thirteen vowels for Proto-Mari, whereas Bereczki (1994) assumes only seven (Table 1).

Table 1. The Proto-Mari vowel system according to Itkonen (1954) and Bereczki (1994).

\begin{tabular}{lcccccc}
\hline & & Itkonen 1954 & & \multicolumn{3}{c}{ Bereczki 1994 } \\
\hline full: & $\mathrm{i}$ & $\ddot{\mathrm{u}}$ & $\mathrm{u}$ & $\mathrm{i}$ & $\ddot{\mathrm{u}}$ & $\mathrm{u}$ \\
& $\mathrm{e}$ & $\ddot{\mathrm{o}}$ & $\mathrm{o}$ & $\mathrm{e}$ & $\ddot{\mathrm{o}}$ & $\mathrm{o}$ \\
& $\varepsilon$ & & $\mathrm{a}$ & & & $\mathrm{a}$ \\
& $\ddot{\mathrm{a}}$ & & $\mathrm{a}$ & & \\
reduced: & $\breve{\mathrm{i}}(\sim \partial)$ & $\breve{\mathrm{u}}$ & $\breve{\mathrm{u}}$ & & & \\
\hline
\end{tabular}

It is interesting that two scholars have reached dramatically different conclusions regarding the Proto-Mari vowel system, as the Mari varieties are genetically very closely related to each other and show rather straightforward vowel correspondences. There are two key points of disagreement: the series of close reduced vowels postulated by Itkonen but rejected by Bereczki, and the number of open or open-mid vowels (Itkonen's four vs. Bereczki's one). Both questions will be reviewed below. In addition, the evidence for the reconstruction of the phoneme *ö will be examined, as in all Mari varieties / $\ddot{o} /$ shows distributional peculiarities that suggest its secondary origin.

All Mari lexical material cited in this study derives from Moisio \& Saarinen's Tscheremissisches Wörterbuch (2008; henceforth TschWb). Forms are rendered in a broad near-phonologi-

* I am obliged to Juho Pystynen and an anonymous referee for remarks that have helped to improve this paper. 
cal transcription, as a thorough analysis of Mari dialect phonology cannot be attempted in this paper. For the purpose of phonological reconstruction this seems justified, even though the possibility of errors in the simplification of the phonetic transcriptions in TschWb is a drawback. For ease of reading, reduced vowels other than schwa $(\partial, \hat{\partial})$ are indicated with a breve $(\breve{\imath}, \breve{u}, \breve{u}, \breve{o})$ instead of sideways and rotated characters traditionally used in the Uralic Phonetic Alphabet. Mari can hardly be regarded a single language, but because the purpose of this study is not to address questions of dialect and language boundaries, the term 'variety' is used to refer to the traditional Mari regional lects.

\section{The close reduced vowels}

All the Mari varieties documented in TschWb, except for Bolshoj Kil'mez (Ki), possess reduced vowels in initial syllables that contrast phonologically with full vowels. The number of contrasting reduced vowels varies between one and three, as seen in Table 2.

Table 2. The reduced vowel phonemes in Mari varieties.

\begin{tabular}{|c|c|}
\hline variety & reduced vowels \\
\hline E (B Ka Kr M MU S) & /ə/ \\
\hline $\mathrm{U}$ & 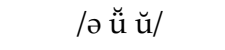 \\
\hline $\mathrm{V}$ & / $\breve{\mathrm{u}} \breve{\mathrm{u}} \breve{~} /$ \\
\hline $\mathrm{Nw}$ & 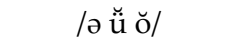 \\
\hline W & /ə əิ/ \\
\hline
\end{tabular}

According to Itkonen (1954) the contrast between full and reduced vowels was already present in Proto-Mari. The most common reflexes of Itkonen's Proto-Mari reduced and close full vowels in the attested varieties are shown in Table 3. As the table shows, in Ki all reduced vowels merged with full vowels, in E labial reduced vowels merged with full vowels, whereas $\mathrm{U}, \mathrm{V}, \mathrm{Nw}$ and $\mathrm{W}$ kept the reflexes of full and reduced vowels consistently apart (in $W *_{1}$ and * ${ }_{\mathrm{u}}$ merged, however).

Table 3. The most common reflexes of Proto-Mari close full and reduced vowels according to Itkonen's (1954) reconstruction.

\begin{tabular}{|c|c|c|c|c|c|c|}
\hline Proto-Mari & E & $\mathrm{Ki}$ & $\mathrm{U}$ & $\mathrm{V}$ & $\mathrm{Nw}$ & W \\
\hline$*_{1}(\sim \partial)$ & ә & $\mathrm{i}$ & ә & $\breve{1}$ & ә & $\partial$ \\
\hline$* \breve{\mathrm{u}}$ & $\ddot{\mathrm{u}}$ & $\ddot{\mathrm{u}}$ & $\breve{\mathrm{u}}$ & $\breve{\mathrm{u}}$ & $\breve{\mathrm{u}}$ & ә \\
\hline${ }^{*} \breve{\mathrm{u}}$ & $\mathrm{u}$ & $\mathrm{u}$ & $\breve{\mathrm{u}}$ & $\breve{\mathrm{u}}$ & $\breve{\mathrm{o}}$ & â \\
\hline$*_{i}$ & $\mathrm{i}$ & $\mathrm{i}$ & $\mathrm{i}$ & $\mathrm{i}$ & $\mathrm{i}$ & $\mathrm{i}$ \\
\hline * $\ddot{\mathrm{u}}$ & ü & ü & $\ddot{\mathrm{u}}$ & $\ddot{\mathrm{u}}$ & $\ddot{\mathrm{u}}$ & $\ddot{u}$ \\
\hline${ }^{*} \mathrm{u}$ & $\mathrm{u}$ & $\mathrm{u}$ & $\mathrm{u}$ & $\mathrm{u}$ & $\mathrm{u}$ & $\mathrm{u}$ \\
\hline
\end{tabular}

Bereczki (1994: 65-84) rejects Itkonen's series of Proto-Mari reduced vowels, and maintains that attested reduced vowels represent secondary developments of original full vowels. His arguments for this view consist of two main points. First, according to Bereczki reduced vowels show irregular correspondences between Mari varieties, which would support their 
secondary origin. Second, Bereczki claims that reduced vowels originated in loanwords from Turkic languages and then spread to native vocabulary; neighboring Chuvash and Tatar, which have heavily influenced Mari both structurally and lexically, possess a very similar contrast between full and reduced vowels. He summarizes his arguments for the secondary origin of reduced vowels as follows:

"In den benachbarten türkischen Sprachen, im Tschuwassischen und Tatarischen entwickelten sich aus den ursprünglichen Vokalen ${ }^{*} i,{ }^{*} u,{ }^{*} \ddot{u}$ die Vokale $\partial, \breve{u}, \breve{u}$, hier aber im gesamten Sprachgebiet und im jedem Wort. Im Tscheremissischen erscheinen diese Vokale in erster Linie in den tschuwassischen und tatarischen Lehnwörtern, in den ursprünglichen, eigenen Wörtern kommt sie seltener vor und oft variieren dialektal.” (Bereczki 1988: 337)

Bereczki's claim that reduced vowels are rare in inherited Mari vocabulary is false, however. Lists of Uralic etymologies for Mari words with reduced vowels are given in Appendix B, and they include a total of 85 examples of inherited words with reduced vowels. In fact, reduced vowels are more common than close full vowels $\left({ }^{*} \mathrm{i},{ }^{*} \ddot{\mathrm{u}},{ }^{*} \mathrm{u}\right)$ in inherited vocabulary. We shall return to the Uralic background of reduced and close full vowels below.

Bereczki's account of the history of reduced vowels in Mari presupposes that they are a product of irregular change, as his postulated changes ${ }^{*} i>{ }^{*} \partial,{ }^{*} \ddot{\mathrm{u}}>{ }^{*} \breve{\mathrm{u}}$ and ${ }^{*} \mathrm{u}>{ }^{*} \breve{u}$ cannot be attributed to any conditioning factors. This is evident from the occurrence of words which in Itkonen's reconstruction form minimal and semiminimal pairs between Proto-Mari close full and reduced vowels:

*u vs. ${ }^{*} \breve{\mathbf{u}}$

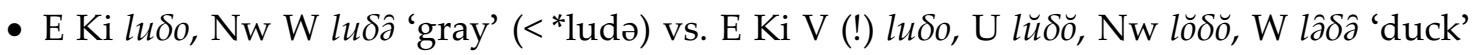
$\left(<{ }^{*}\right.$ lŭdə)

- E V U Nw W šur 'horn' (<*šur) vs. E Ki šur, V U šŭr, Nw šŏr, W šâr 'shit' (< *šŭr)

- W tul 'storm' (<*tul) vs. E Ki tul, V U tŭl, Nw tŏl, W tâl 'fire' (<*tŭl)

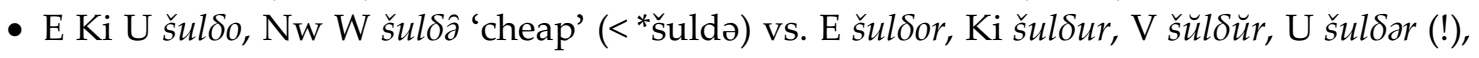

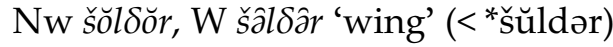

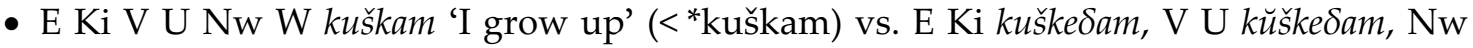

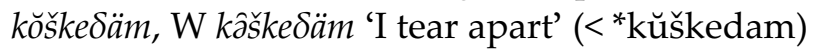

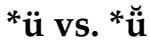

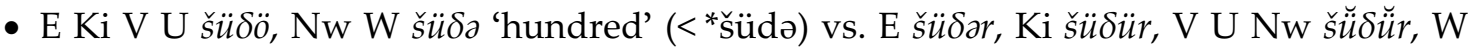

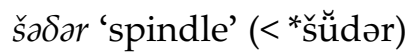

*i vs. ${ }^{*} \check{\mathbf{i}}$

- E Ki V U Nw W kiš 'resin' (< ${ }^{*}$ kiš) vs. E U Nw W kəškem, V kľškem, Ki kiškem 'I throw; I pour' $\left(<{ }^{*}\right.$ ǩškem)

Let us first consider Bereczki's argument that many words with first-syllable reduced vowels show irregular vowel correspondences between Mari varieties, and that the irregularities would support the idea that reduced vowels emerged through irregular sound change. In the examples above, for instance, there are two occurrences of irregular full vowels in cases

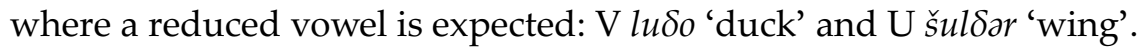

Bereczki (1994: 72) states that approximately $30 \%$ of the words with reduced vowels show an irregular vowel reflex in at least one variety, which in his view supports the idea that vowel 
reduction is a secondary phenomenon. This argument is fallacious, however: even if $30 \%$ of the words show an irregular vowel in some variety, it does not follow that every reduced vowel in every variety is a product of irregular change. Bereczki (1994: 69) also refers to varieties where there is synchronic variation between reduced and full vowels, and provides examples of his own fieldwork data from the Arbor variety, where variant forms such as purra pura '(s)he comes in' and ı̌läš INF ilen GER 'live' are attested even within a single idiolect. It is, however, difficult to see why such variation would support his conclusion that the distinction between full and reduced vowels arose through irregular sound change. It is a basic sociolinguistic fact that variation can result from many factors, including ongoing sound change and dialect coalescence. These weaknesses in Bereczki's argumentation already cast serious doubts on the validity of his account of the history of Mari reduced vowels.

It must be noted that if one intends to make statistical claims about regularity or irregularity, it is entirely uninformative to calculate the percentage of word-roots that show an irregular form in any arbitrary variety, because such a figure reveals nothing of the actual frequency of regular and irregular forms. Instead, the reflexes of assumed Proto-Mari reduced vowels must be separately studied in each Mari variety. In order to perform such a study, the word-roots for which a Proto-Mari reduced vowel ( $\left.{ }^{*},{ }^{*} \breve{\mathrm{u}},{ }^{*} \breve{\mathrm{u}}\right)$ could be postulated in Itkonen's system of reconstruction were compiled from $\mathrm{TschWb}$, and the vowels attested for each root in each variety were put in tables. Recent borrowings (from Chuvash, Tatar, Permic and Russian) were excluded, as they include words that have spread between already differentiated Mari varieties and may thus exhibit irregularities. The data is given in Appendix A.

Let us first consider reduced rounded vowels. As only V, U, Nw and $\mathrm{W}$ contrast the reflexes of reduced rounded vowels with full ones, data from other varieties is irrelevant here. Figures indicating the absolute number and relative frequency of irregular reflexes of PMari * $\breve{\mathrm{u}}$ and $* \breve{\mathrm{u}}$ in the four varieties are given in Tables 4 and 5 . As we are primarily interested in the phenomenon of vowel reduction here, numbers and percentages of cases of failed vowel reduction (i.e., a full vowel occurring where a reduced one is expected) have also been separately calculated. A part of the irregularities in the material are not directly related to vowel reduction: there are also instances of unexpected vowel quality (e.g., W kâpš 'nap, fuzz' instead

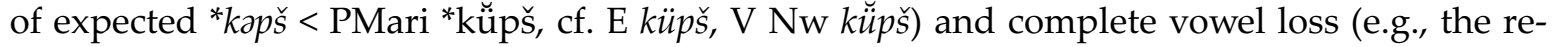
flexive pronoun ške aške, Ki iške < * as occurrences of reduced vowels, as it appears evident that they have involved a reduced vowel as an intermediate stage..$^{1}$ Instances where both a regular and an irregular form is at-

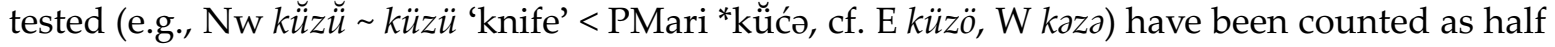
an occurrence of both.

As Tables 4 and 5 show, the presence of a reduced vowel as the reflex of Itkonen's PMari * $\breve{\mathrm{u}}$ and $* \breve{\mathrm{u}}$ is in most cases quite consistent, with reduction regularity rates in the range of $87-$ $95 \%$. A curious exception is formed by the reflexes of * $\breve{\mathrm{u}}$ in the Upsha variety, where there is remarkable inconsistency between $\ddot{u}$ (26,5 occurrences) and $\breve{\ddot{u}}$ (45 occurrences). This variation

\footnotetext{
${ }^{1}$ As pointed out by the anonymous referee, some words that would superficially seem to exhibit vowel loss rather seem to involve loanwords in which a prothetic vowel was added for phonotactic reasons in some varieties

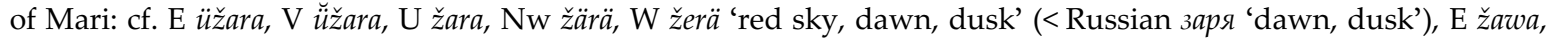
užawa, V žawa, U ǔžawa, Nw žawa, âžawa, W žawa 'toad' (<Russian жабa 'toad'). To this group one can also count $\mathrm{E}$ uškal, V ǔškal, U škal, ǔškal, Nw W âškal, škal 'cow'. This word has been considered cognate with Mordvin skal and Udmurt iskal, âskal, skal, sikkal 'cow', supposedly reflecting a proto-form *uskalV (UEW: 805; HPUL: 552). In light of the irregular sound correspondences this is not justified; the forms rather look like recent nativizations of a nonUralic word of the shape *skal, but the source of the word remains unknown.
} 
Table 4. The regularity of reflexes of PMari *ŭ in V, U, Nw and W Mari.

\begin{tabular}{lccccc}
\hline Proto-Mari * ${ }^{\mathbf{u}}$ & $\mathrm{U}$ & $\mathrm{V}$ & $\mathrm{Nw}$ & $\mathrm{W}$ & all varieties \\
\hline total reflexes & 135 & 98 & 126 & 129 & 488 \\
irregular reflexes & 16 & 14,5 & 21,5 & 13 & 65 \\
irregular full vowels & 12 & 9,5 & 6 & 6 & 33,5 \\
\hline regularity rate & $88 \%$ & $85 \%$ & $83 \%$ & $90 \%$ & $87 \%$ \\
reduction regularity rate & $91 \%$ & $90 \%$ & $95 \%$ & $95 \%$ & $93 \%$ \\
\hline
\end{tabular}

Table 5. The regularity of reflexes of PMari * $\breve{\mathrm{u}}$ in $\mathrm{V}, \mathrm{U}, \mathrm{Nw}$ and $\mathrm{W}$ Mari.

\begin{tabular}{|c|c|c|c|c|c|}
\hline Proto-Mari $* \breve{\mathbf{u}}$ & $\mathrm{U}$ & $\mathrm{V}$ & $\mathrm{Nw}$ & W & all varieties \\
\hline total reflexes & 72 & 63 & 67 & 71 & 273 \\
\hline irregular reflexes & 27 & 11 & 13,5 & 7 & 58,5 \\
\hline irregular full vowels & 26,5 & 8 & 4,5 & 4 & 43 \\
\hline regularity rate & $63 \%$ & $83 \%$ & $80 \%$ & $92 \%$ & $79 \%$ \\
\hline reduction regularity rate & $63 \%$ & $87 \%$ & $93 \%$ & $94 \%$ & $84 \%$ \\
\hline
\end{tabular}

Table 6. The regularity of reflexes of PMari ${ }_{1}$ in Mari varieties.

\begin{tabular}{|c|c|c|c|c|c|c|c|c|c|c|c|}
\hline Proto-Mari ${ }^{*}$ & B & $\mathbf{K r}$ & $\mathbf{K a}$ & $S$ & $\mathbf{M}$ & MU & $\mathbf{U}$ & V & Nw & $\mathbf{W}$ & all \\
\hline total reflexes & 110 & 75 & 68 & 109 & 105 & 82 & 113 & 89 & 105 & 108 & 964 \\
\hline irregular reflexes & 19 & 16,5 & 16 & 20,5 & 12,5 & 9 & 17,5 & 9,5 & 16 & 7 & 143,5 \\
\hline irregular full & 13 & 13,5 & 14 & 19,5 & 11,5 & 6 & 5 & 2 & 6 & 5 & 95,5 \\
\hline irregular reduced & 4,5 & 0,5 & 1 & - & - & 2 & - & - & - & - & 8 \\
\hline regularity rate & $83 \%$ & $78 \%$ & $76 \%$ & $81 \%$ & $88 \%$ & $89 \%$ & $85 \%$ & $89 \%$ & $85 \%$ & $94 \%$ & $85 \%$ \\
\hline reduction regularity & $84 \%$ & $81 \%$ & $78 \%$ & $82 \%$ & $89 \%$ & $90 \%$ & $96 \%$ & $98 \%$ & $94 \%$ & $95 \%$ & $89 \%$ \\
\hline
\end{tabular}

obviously has some special explanation, but as the Upsha material in TschWb was originally recorded by Yrjö Wichmann from a single informant, it is difficult to say anything definite about the issue without additional sources of data.

Next, let us consider the case of Itkonen's PMari $*_{\mathfrak{1}}$, which can be reflected as a reduced vowel ( $\partial$; in $\mathrm{V} \breve{l}$ ) in all varieties except for $\mathrm{Ki}$ which lacks reduced vowels altogether. However, as discussed by Itkonen (1954: 225-238), there is also a notable number of cases which show $i$ as the reflex of ${ }^{\prime} \mathrm{i}$ in several East Mari varieties. Judging from the material in Appendix $A$, the regular reflex of Itkonen's * $\breve{1}$ would seem to be B Kr Ka $i$ when followed by PMari *ć and B Kr Ka M MU S $i$ when followed by the cluster *nć. There are also instances of $\mathrm{E} i$ in other environments: in initial position, after ${ }^{*} \mathrm{j}$-, before palatalized consonants and adjacent to *̌s, for example. These do not seem to be explicable as results of regular development, even though there obviously are tendencies based on the consonant environment. Taking *ć and *ńc as regular conditioning factors into account, the regularity rates of the reflexes of $*_{1}$ in Mari varieties turn out to be as shown in Table 6 .

As the figures in Tables 4-6 are put together, we have 1725 attested reflexes of Itkonen's PMari reduced vowels $*_{\mathfrak{i}}, * \breve{u}$ and ${ }^{*} \breve{u}$ in Mari varieties that contrast these reflexes with full vowels. Of these reflexes $1545(90 \%)$ are regular in terms of vowel reduction, i.e. a reduced vowel 


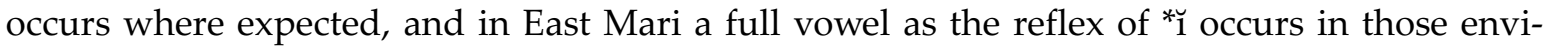
ronments where expected.

These figures reveal the inadequacy of Bereczki's account of the history of Mari reduced vowels: in his model all occurrences of reduced vowels have to be interpreted as having undergone an irregular change, whereas only the exceptional occurrences of full vowels would represent regular development. In Bereczki's theory, of course, also those word-roots that have close full vowels according to Itkonen's reconstruction could be added to the instances of regular development, but because such roots are fewer in number than roots displaying reduced vowels, the presence of vowel reduction would still remain more common than its absence. While Itkonen's reconstruction successfully explains $90 \%$ of the material, the explanatory power of Bereczki's model is virtually nil: by postulating rampant irregular sound change, it provides no actual explanation to either the presence or the absence of a reduced vowel in any single word-root.

It bears mentioning that there is yet another fatal problem in Bereczki's argument: as already shown by Itkonen (1954), Mari reduced and close full vowels have different Uralic origins. This becomes evident by examining the etymologies for Mari words which have the PMari vowel ${ }^{*} \mathrm{i},{ }_{\breve{1}},{ }^{*} \ddot{\mathrm{u}},{ }^{*} \breve{\mathrm{u}},{ }^{*} \mathrm{u}$ or ${ }^{*} \mathrm{u}$ according to Itkonen's reconstruction. In this connection we can ignore Mari monosyllabic vocalic roots of Uralic origin, as due to a phonotactic restriction reduced vowels do not occur in Mari stems of the type *CV-. The remainder of the etymological material (see Appendix B) allows the following two generalizations to be made.

1) PMari ${ }^{*} \breve{i}$ and ${ }^{*} \breve{\mathrm{u}}$ are reflexes of PU close and mid front vowels $\left({ }^{*} i,{ }^{*} \ddot{\mathrm{u}}\right.$ and ${ }^{*} e$ ), whereas PMari ${ }^{*} \mathrm{i}$ and ${ }^{*} \ddot{\mathrm{u}}$ are reflexes of PU $*^{*}$ and ${ }^{*} \mathrm{i}$. There appears to be one minor conditioned exception: PU * jä- and *nä- can be reflected as PMari *jiّ-.

2) PMari ${ }^{*} \breve{u}$ is the reflex of PU *u, whereas PMari ${ }^{*} u$ occurs as the reflex of PU *o. There is a conditioned exception: PMari ${ }^{*} \breve{\mathrm{u}}$ can also reflect PU ${ }^{*} \mathrm{O}$ when adjacent to a labial consonant $\left({ }^{*} \mathrm{p},{ }^{*} \mathrm{~m}\right.$ or $\left.{ }^{*} \mathrm{w}\right)$.

Most of the regular correspondences between Mari reduced vowels and their Uralic predecessors that underlie these generalizations had already been discovered by Itkonen (1954), but they are completely ignored by Bereczki (1988; 1994). Obviously, no such regularities could occur if reduced vowels had developed from full vowels through irregular sound change.

Bereczki's account of the origin of Mari reduced vowels is flawed, as it explains neither the regular vowel correspondences between Mari varieties nor the regular vowel correspondences between Mari and other Uralic languages. Thus, both internal and external comparison clearly indicates that Mari initial-syllable reduced vowels go back to Proto-Mari vowel phonemes that were distinct from the sources of close full vowels $i, \ddot{u}$ and $u$ in the same varieties, as maintained by Itkonen (1954). Thus, two series of close vowels must be reconstructed for Proto-Mari: ${ }^{*} \mathrm{i},{ }^{*} \ddot{\mathrm{u}},{ }^{*} \mathrm{u}$ vs. ${ }^{*} \mathrm{i},{ }^{*} \breve{\mathrm{u}},{ }^{*} \breve{\mathrm{u}}$.

Even though Bereczki's claim that Mari reduced vowels originated through irregular sound change under Turkic influence is untenable, it cannot be denied that the reduced vowels in V, U, Nw and $\mathrm{W}$ are strikingly analogous to those in the neighboring Turkic languages. Thus, it appears highly likely that language contact has nevertheless played a role in the development of Mari reduced vowels. The original distinctive feature between Proto-Mari ${ }^{*} \mathrm{i},{ }^{*} \ddot{\mathrm{u}}$, ${ }^{*} \mathrm{u}$ and ${ }_{\breve{1}},{ }_{\breve{u} \mathrm{u}}{ }^{*} \breve{\mathrm{u}}$ was not necessarily full vs. reduced articulation (e.g, IPA [u] vs. [ü]). More probably, the opposition has became phonetically restructured as such under the influence of Turkic languages with reduced vowels. It could also have originally been a distinction of length (IPA [u:] : [u]), height (IPA [u] : [u] ), or a combination of length and height (IPA [u] : [u] ). 
It is worth noting that there are many examples of similar restructurings of vowel systems due to language contact. For example, Salminen describes how the Forest Nenets vowel system has become restructured under East Khanty influence so that the resulting system is in essential respects identical to the model in the contact language:

“...at least three of the main characteristics of the Forest Nenets vowel system, namely the nature of the quantity opposition, the smaller number of contrasts in non-initial or unstressed syllables, as well as the presence of metaphony leading to morphological vowel alternations, bear striking similarities to what is found in Eastern Khanty, which is also known to have provided Forest Nenets with the bulk of its loanwords. A look at Honti's (1984: 20) description of the vowel system in the Tromagan dialect of Eastern Khanty shows that when the three peripheral vowels, which could not possibly be reflected in Forest Nenets where the frontness of the vowel depends on the palatality of the preceding consonant and the syllable as a whole, are eliminated, the remaining system of cardinal vowels consists of exactly six long vowels and four short vowels, and even the phonetic match is very close, especially if recent sound changes in Eastern Khanty dialects are taken into account. A claim can therefore be put forward that the Forest Nenets vowel system was reorganized following a specifically Eastern Khanty model.” (Salminen 1997: 368)

Thus, Bereczki (1994) is still probably right in attributing the nature of the opposition of Mari full and reduced vowels to influence of Turkic languages. Contrary to his claim, however, this influence cannot account for the origin of this opposition, which must go back to ProtoMari as maintained by Itkonen (1954). The original phonetic nature of the opposition in ProtoMari remains unclear, and the present way of marking the Proto-Mari predecessors of Mari reduced vowels with a breve $\left({ }^{*} \breve{1}, * \breve{\mathrm{u}},{ }^{*} \breve{\mathrm{u}}\right)$ is merely a practical solution for indicating the opposition in reconstructed forms.

\section{Proto-Mari *ö}

Both Itkonen (1954) and Bereczki (1994) postulate a vowel phoneme *ö for Proto-Mari. Nevertheless, this vowel shows distributional peculiarities which require its status in Proto-Mari to be reassessed. Disregarding Tatar and Chuvash loanwords which may have spread between already distinct Mari varieties, TschWb contains 22 roots which uniformly have the front mid rounded vowel $\ddot{o}$ in all Mari varieties; for the sake of brevity, only E and W forms are cited here:

- E öram, W öräm 'I am amazed'

- E, W örסem 'I grow fat'

- E, W örठaž 'side (body part)'

- E öraš, örš, W öraš 'bullfinch'

- E öraš, öršs, W öraš 'mustache'

- E, W jörem 'I put out (a fire)'

- E, W jöraktem 'I knock over'

- E körrö, W körra 'inside'

- E löča, (B Ka) lọ̈ça, W löčä 'it swells (due to moisture)'

- E, W mör 'strawberry'

- E nörtmö, mörtńö, W mörtńi 'roe'

- E nöryö, W nörya 'cartilage'

- E nörö, W nöra 'pliable'

- E pöč́ž, (B) pöçöž, W pöča 'lingonberry'

- E pörSam, W pörtäm 'I go round' 
- E pörš, W pöršǟša 'rime'

- E pöraž, pörž, W pöraž, pörža 'brother-in-law'

- $E, W$ šör 'side'

- E, W šörem 'I guess, I solve'

- E šöryaltem, W šöryältem 'I tie loops'

- E šörtñö, W šörtńi 'gold'

- E törra, W töryä taryä 'it gallops'

Both Itkonen (1954: 213-215) and Bereczki (1994: 116-118) acknowledge that the reconstructed phoneme ${ }^{*}$ ö shows a distributional peculiarity: it is almost completely restricted to the position before ${ }^{*}$. This contextual factor was already noted by Räsänen (1920: 97), who suggested that Proto-Mari had no vowel ${ }^{*} \ddot{\mathrm{o}}$, and that modern Mari $\ddot{o}$ is the reflex of Proto-Mari ${ }^{*} \ddot{\mathrm{u}}$ before ${ }^{*}$ r. Itkonen, however, supports the reconstruction of a distinct Proto-Mari vowel *ö by noting that not only Finno-Ugric *ü but also other Finno-Ugric vowels may be reflected as $\ddot{o}$ in Mari, for example:

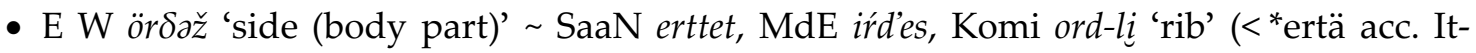
konen)

- E W mör 'strawberry' SaaN muorji, Fi marja 'berry' (<*marja acc. Itkonen)

Itkonen's argument is entirely unconvincing, however. One must note that also ProtoMari ${ }^{*} \ddot{\mathrm{u}}$ - when reflected as $\ddot{u}$ in all varieties - can appear as the reflex of several Uralic vowel phonemes, including for instance *e and *a in Itkonen's reconstruction: cf., e.g., E, W

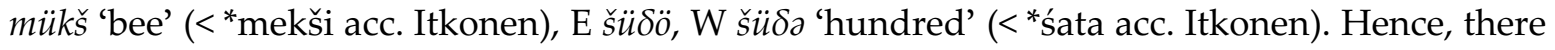
is no reason why Mari $\ddot{o}$ in words such as ör $\delta z z ̌$ 'side (body part)' and mör 'strawberry' could not go back to Proto-Mari * $\ddot{\mathrm{u}}$ as well, regardless of the actual Uralic source of this sound in each word. Thus, Itkonen's argument for treating *ö as an independent Proto-Mari phoneme is based on a confusion between the Proto-Mari and the Uralic levels of reconstruction.

If we restrict our analysis to the actual Mari material, it appears impossible to find clear evidence for reconstructing a phonological opposition * $\ddot{\mathrm{u}}$ : *ö into Proto-Mari. Almost all the cases that uniformly show $\ddot{o}$ in all varieties involve the position before $r$, and in the same environment $\ddot{u}$ is not found. While the sequence $\ddot{u} r$ does occur in East Mari, in such cases it goes back to PMari *ür and regularly corresponds to V U Nw $\breve{u} r$ and W $\partial r$, as in the following examples:

- E küram, V U kürram, Nw kürräm, W karäm 'I tear off' (<PMari *küram)

- E šürrö, V U šürryö, Nw šürryü, W šarya 'cheek, face' (<PMari *šürgə)

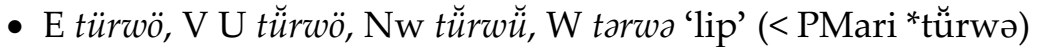

- E wür, V U Nw würr, W war 'blood' (<PMari *wür)

Hence, it appears evident that there has been a regular shift ${ }^{*} \ddot{\mathrm{u}}>\ddot{o}$ before $r$ in all varieties.

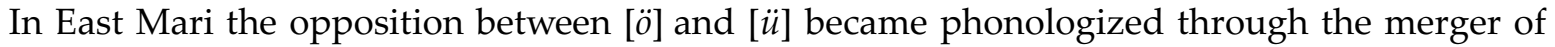
reduced labial vowels with full ones: PMari *ür > E ör, but PMari *ür > E ür.

In addition, $\ddot{o}$ is found in two words before the affricate *č: E löča, W löčä 'it swells (due to moisture)' and E pöč́ž, W pöča 'lingonberry'. These cases have no straightforward explanation. One cannot assume a regular lowering ${ }^{*} \ddot{\mathrm{u}}>\ddot{o}$ before ${ }^{*} \check{\mathrm{c}}$, because the sequence ${ }^{*}$ - $\mathrm{u} c ̌-$ is preserved in four cases: E tüč́am čüčam, U tücam, Nw tücäm, W čüčäm 'I close (a door)' (<PMari *tüčä*čüčä-), V čüčem, W čüčem 'I make a hole' (<PMari *čüče-), E čüča, B Kr ç̣üçä, Nw tücä 'it drips' (<PMari *čüče-), and E čüčkem, B ç̣üç̌kem, U cuckem (!), Nw cückem 'I shake my body' (< PMari 
*čüčke-). Thus, löča and pöčž could theoretically support the reconstruction of an opposition

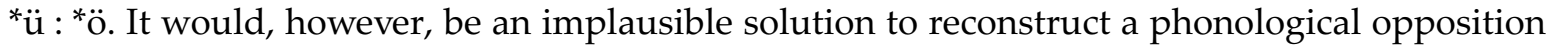
of two vowels that was only realized before the consonant ${ }^{*} \check{\mathrm{c}}$, especially as the number of examples supporting the postulation of such an opposition is limited to two word-roots.

It is worth noting that even in loanwords it is difficult to find examples of widespread Mari $\ddot{o}$ in contexts other than before $r$. Rare exceptions are the Tatar loanwords E W jön 'means, way', E W kök 'gray (horse)', and E töwa, W töwä 'hill'. More commonly, Tatar loanwords with ö show irregular vowel correspondences: e.g., B Ka pölek, $\mathrm{Kr}$ pölek pelek, S pelek, M pölök, U pelak, Nw peläk 'gift'. All this points to the conclusion that $\ddot{o}$ was established as an independent phoneme only after the breaking up of Proto-Mari and the independent development of Mari varieties. However, [ö] may have existed as an allophone of ${ }^{*} \ddot{u}$ before ${ }^{*} \mathrm{r}$ already in Proto-Mari.

There is also a handful of words in which some varieties show $\ddot{o}$ corresponding to $\ddot{u}$ in other varieties. As already suggested by Itkonen (1954: 222), these correspondences seem to re-

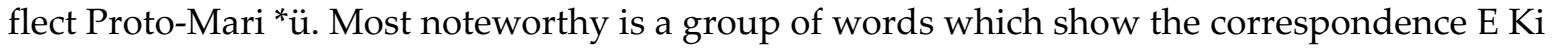
V U $\ddot{o} \sim \mathrm{Nw}$ W $\ddot{u}:$

- B nöläš, Kr V nölaš, Ki nöl’aš, M nölaš nelaš (!), MU nelaš (!), V nölaš, U nelaš lelaš (!), Nw lüläkš, W lüläš 'spindle ring, wheel'

- E nölpö lölpö, V nölpö, U lölpö, Nw lülpü, W lülpa 'alder'

- E nöltem löltem, V U nöltem, Nw W lültem 'I raise, lift'

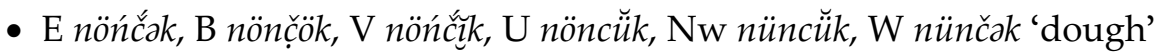

- E nöšmö, Nw nüšmü̈, W nüšmü nüšma 'seed'

- E nöštalam, Nw W nüštaläm 'I knead dough'

In addition, one can also count $\mathrm{M}$ nöla pikš 'arrow with a bone head' (pikš 'arrow') in this group. The word is not attested in other varieties, but we can assume it goes back to Proto-Mari *nülə. This is suggested both by the apparent regularity of the correspondence on account of the six cases listed above, and by the fact that the form *nülə is the regular reflex of PU *nili 'arrow'; other examples of the development PU * ${ }_{i}>$ PMari * $\ddot{u}$ can be found in Appendix B.

It is notable that the phonological context is similar in all six words: there is a preceding coronal sonorant $(n \sim l)$ and a following coronal continuant $(l, n$ or $\check{s})$. Regardless of how exactly we choose to define the context for the shift $* \ddot{\mathrm{u}}>\mathrm{E} \ddot{o}$ in these words, the correspondence is evidently regular: there are no counterexamples showing a retention of $\ddot{\ddot{u}}$ in a comparable context. It must be noted that the consonant ${ }^{*} \mathrm{~d}(>\delta)$ apparently did not count as a coronal

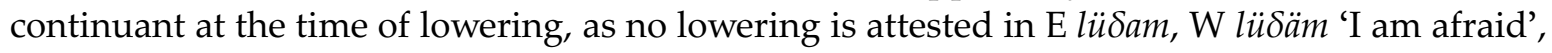

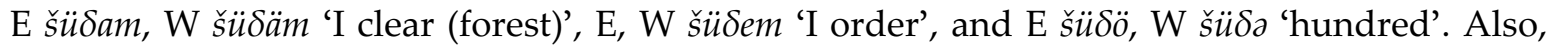
the phonetic motive for the lowering ${ }^{*} \ddot{\mathrm{u}}>\ddot{\mathrm{o}}$ in the defined context remains obscure, but this does not prevent us from recognizing the regularity of the development.

There are also two other possible cases of the same correspondence in different environments:

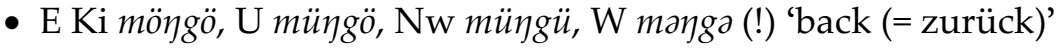

- B Kr Ki MU S V kö, M ke (!), U (!) Nw W kü 'who'

The first word seems to have undergone the same East Mari change ${ }^{*} \ddot{\mathrm{u}}>{ }^{*} \ddot{\mathrm{o}}$, even though here we find $\ddot{u}$ in Upsha, perhaps due to dialect borrowing. However, in $\mathrm{W}$ there is a reduced vowel $\partial(<* \breve{u})$. From an internal point of view it would seem plausible to treat this as a secondary case of irregular vowel reduction, but external data suggest otherwise: the word goes back to PU *münä- (UEW: 276-277; HPUL: 546), and W $a<* \breve{u}$ is the expected reflex of PU *ü. 
The interrogative pronoun 'who' is even more obscure. Here a vowel change * $\ddot{\mathrm{u}}>\ddot{o}$ has taken place in all Eastern varieties except for $M$ and $U$, but this definitely cannot be regular, as in other CV-stems * $\ddot{\mathrm{u}}$ is preserved throughout Mari:

- B Ka Ki küj, Kr S M MU V U Nw W kü ‘stone’ (<PMari *kü)

- B Ka Ki müj, Kr S M MU V U Nw W mü 'honey' (< PMari *mü)

- B Ka Ki püj, Kr S M MU V U Nw W pü 'tooth' (<PMari *pü)

- B Ka šüj, Ki śüj, Kr S M MU U Nw W šü 'pus' (<PMari *sü)

- B Ki š̈̈j, Kr S M MU V U Nw W š̈̈ 'charcoal' (<PMari *šü)

- B Ka Ki šüj, Kr S M MU V U Nw W šü 'neck' (< PMari *šü)

Bereczki (1992) reconstructs these words as glide stems ( ${ }^{*} k u ̈ j, ~{ }^{*}$ müj, etc.) on the basis of the $\mathrm{B} \mathrm{Ka}$ and $\mathrm{Ki}$ forms. If this was correct, it could account for their difference to kö 'who'. It is highly probable, however, that $\mathrm{B} \mathrm{Ka} \mathrm{Ki}-j$ originated as a hiatus-filling sound before suffixes beginning with a vowel, and was then analogically generalized as a part of the stem. The secondary status of $-j$ in these varieties is also evident from the fact that it appears in the place of any deleted PU consonant: cf. Ki küj 'stone' (<PU *kiwi), püj 'tooth' (<PU *pini), śüj 'pus' (<PU *säji), šüj 'charcoal' (<PU *śüdii), šüj 'neck' (<PU *śepä). The word müj 'honey’ (<*mü), in turn, is a loan from Proto-Udmurt *mü 'honey' ( $>$ Udmurt $m u$, dial. mü; cognate with Komi $m a)$. It cannot be a direct reflex of PU *meti 'honey', because no loss of intervocalic *t has taken place in Mari, as opposed to Permic (cf. Bereczki 1992: 40). ${ }^{2}$ Moreover, it is not even clear that the B Ka Ki glide $j$ in these words is a phonological segment; Sebeok and Ingermann (1961: 7)

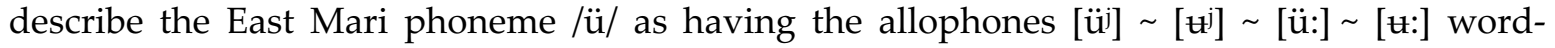
finally and $[\ddot{\mathrm{u}}] \sim\left[\mathfrak{u}^{\mathrm{i}}\right]$ before another vowel. The vowel $/ \mathrm{i} /$ is described as having the same kind of phonetic glide component in the same environments.

The vowel change * $\ddot{\mathrm{u}}>\ddot{o}$ in $k \ddot{o}$ 'who' thus must be irregular, and its reason remains unclear; perhaps it is related to the high frequency of the pronoun. An even more mysterious question is why the pronoun contains a labial vowel in the first place, as it goes back to PU *ke (cf. North Saami gii, Finnish ke-n, Mordvin ki, Komi, Udmurt ki-n, Hungarian ki, Nganasan si-li 'who'). The $\mathrm{M}$ form $k e$ is noteworthy in this connection. Despite its limited distribution, it is tempting to consider $\mathrm{M} k e$ an archaism, as it is exactly the expected reflex of PU *ke 'who': cf. M me 'we' < PU *me (> North Saami mii, Finnish me, Mordvin mi-ń, Komi, Udmurt mi, Hungarian $m i$, Nganasan $m i-\eta$ ) and M te 'you (pl.)' < PU *te (> North Saami dii, Finnish te, Mordvin $t i-n$, Komi, Udmurt $t i$, Hungarian $t i$, Nganasan $t i-\eta)$. Thus, the forms $k \ddot{o}$ and $k \ddot{u}$ in other varieties would seem to be the result of some post-Proto-Mari irregular development.

In addition to the words discussed above, there are three nouns that seem to show a shift * $\ddot{\mathrm{u}}>\ddot{\mathrm{o}}$ in a more restricted set of varieties:

- M V šön, MU šön šin (!), S šön šün, Ka Kr U Nw W šün, Ki śün, B šün sün (!) 'vein'

- V šöm, M šöm šüm, B Ka Ki Kr S MU šüm, U Nw šüm (!), W süm (!) 'scale'

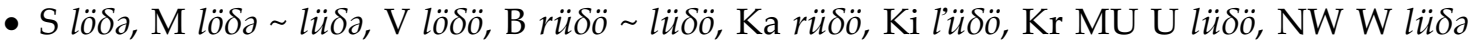
'trap (e.g. for mice)'

2 According to an alternative etymology, PMari *mü 'honey' is unrelated to Udmurt $m u$, $m \dot{u}$, and instead cognate with Proto-Khanty *māy (VVj mäy, Irt máj, Ni Kaz maw 'honey') and Proto-Mansi *mäy (E möär, N mājy 'honey') (? < *mäkV; UEW: 266). This seems unlikely, however, because there is a perfect match between PMari and Proto-Udmurt *mü 'honey', and Mari has a large number of Udmurt loanwords in any case. Also, the vowel correspondence Proto-Khanty *ā $\sim$ Proto-Mansi *ä is atypical of inherited Uralic vocabulary. 
In these cases one can hardly provide a regular account of the forms with $\ddot{o}$, as in each case the dialect distribution of these variants is unique. It is also worth noting that each of these

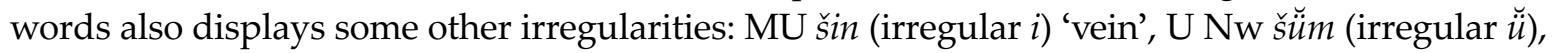
W süm (irregular s-) 'scale', and B Ka rüßö 'trap' (irregular $r$-). ${ }^{3}$ Due to the limited distribution of the forms with $\ddot{o}$ they are no doubt secondary, even though the reasons behind their development remain unclear.

\section{Proto-Mari *e and ${ }^{*} \varepsilon$}

Itkonen (1954: 207-211) reconstructs a PMari opposition between ${ }^{*} \varepsilon(>\mathrm{W} \ddot{a}$, other varieties $e)$ and ${ }^{*} \mathrm{e}\left(>e\right.$ in all varieties). He points out, however, that the reconstructed phoneme ${ }^{*} \varepsilon$ shows a skewed distribution: in nearly all cases it occurs before either ${ }^{*} \mathrm{r}$ or a velar $\left({ }^{*} \mathrm{\eta}\right.$ or $\left.{ }^{*} \mathrm{k}\right)$. In light of this distribution, Bereczki (1994: 92-95) rejects the opposition ${ }^{*} \varepsilon$ : $^{*}$, and regards $W \ddot{a}$ as the result of a change ${ }^{*} \mathrm{e}>\ddot{a}$ in these particular environments. As the common Mari words in $\mathrm{TschWb}$ in which $\mathrm{W} \ddot{a}$ corresponds to $e$ in other varieties are examined, the correspondence is indeed found to be almost exclusively restricted to three kinds of environments:

1) Before a velar:

- W ängar E V U Nw eךer 'river'

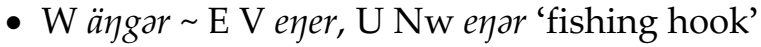

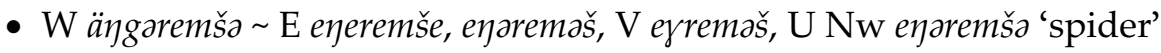

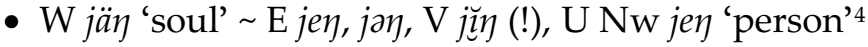

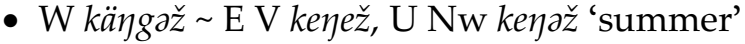

- W läktäm E V U lektam, Nw lektäm 'I go out'

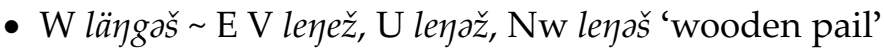

- W mäkšs E V U mekšs 'rotten spot in a tree'

- W mänga E V menge, U Nw menga 'post, stake'

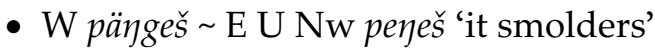

- W šäkš E V U Nw šekš, Ki śekś 'gall'

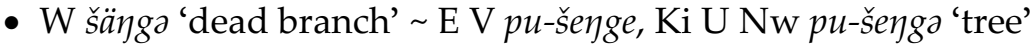

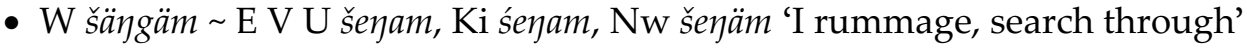

- W täkta E tekte, U tekta 'beehive'

2) Before *r:

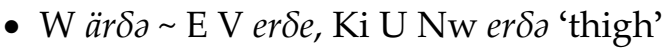

- W äryem E Ki V U Nw eryem 'I coil yarn'

- W ärtńi E V ertńe, U ertńa, Nw ärtńa (!) 'birch-bark container'

- W jär E Ki V U Nw jer 'lake'

- W käryältem E Ki V U keryaltem, Nw keryältem 'I roll up'

- W pärtńä E pertńa, Ki partńi (!), U pertńa 'bud'

- W šär E U Nw šer, Ki śer 'vein'

- W šäryem E šeryem 'I open, disperse, scatter'

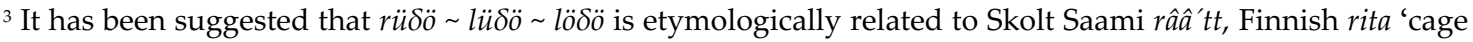
trap' and Komi ri 'well sweep; trigger of a trap' (UEW: 746; HPUL: 553); if correct, then B Ka $r$ - must be an archaism. However, this lexical set is a Wanderwort at best; the vowel correspondences are irregular, and hence the proposed reconstruction *rita cannot be justified.

${ }^{4} \mathrm{Nw}$ jä 'soul' appears to have been borrowed from W. 
- W Šärtńi E šertńe, šartńe (!), Ki šartńi (!), V šertńe, U šertńa, Nw šerńa 'willow'

- W wär E Ki V U wer, Nw wär wer (!) 'place'

- W wärya E V werye, Ki U Nw werya 'kidney'

3) In CV-stems:

- W mä E Ki V U Nw me 'we'

- W tä E Ki V U Nw te 'you (pl.)'

If we disregard Tatar and Chuvash loanwords, the only case in TschWb falling outside

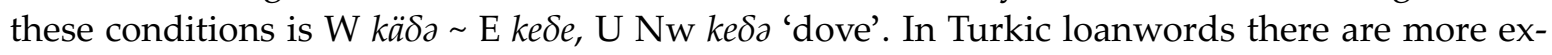
amples of W $\ddot{a}$ in other environments, e.g. W käpšal' E kepšal 'fetter'. Such words, however, have probably been borrowed after the conditioned change ${ }^{*} \mathrm{e}>\mathrm{W} \ddot{a}$. In this case also the irregular correspondence $\mathrm{W} l ; \sim \mathrm{E} l$ points to the word having entered West and East Mari separately.

Next, we need to consider possible counterexamples where PMari *e would have been retained in $\mathrm{W}$ in environments where $\ddot{a}$ is expected. In the case of CV-type stems none occur. Before velars $\mathrm{W} e$ only occurs in loanwords that have obviously diffused between already distinct Mari varieties (e.g., W jeygä E jeyga 'older brother's wife' < Tatar). TschWb cites no etymology for W wek-ät, U wek-at 'at all (in negated sentences)', E wek 'constantly; at all (in negated sentences)', but this must be a loan from Russian век 'century, age, lifetime; for ages, always' (Komi vek 'always, constantly' derives from the same source).

However, there are some examples of $\mathrm{W} a, i$, and $\ddot{o}$ corresponding to $e$ in other varieties:

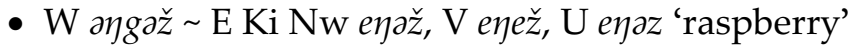

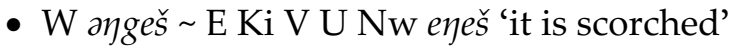

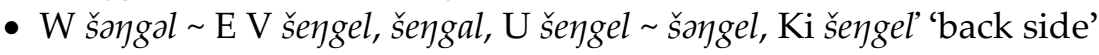

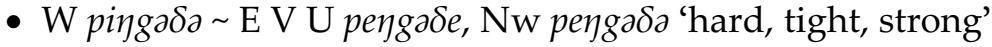

- W töygal E U Nw teygal, Ki teygal' 'bench'

The last two examples are unique correspondences, and as such clearly irregular. The three cases of $\mathrm{W}$ a could theoretically result from some kind of regular development, but this seems unlikely, as further cases of $\mathrm{W}$ a corresponding to $e$ in other varieties are not found in other environments. Hence, these three words hardly serve as counterevidence to the assumption of a regular sound change ${ }^{*} \mathrm{e}>\mathrm{W}$ ä before velars.

The situation is quite different when we take the examples involving $r$ into consideration. There are many cases where all varieties, including $\mathrm{W}$, show $e$ in this environment:

- E V erye, Ki U Nw W erya 'son, boy'

- E Ki V U keram, Nw W keräm 'I stick in'

- E V kerye, Ki U Nw W kerya 'woodpecker'

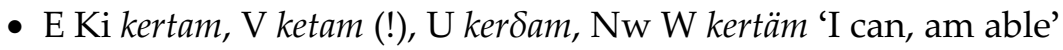

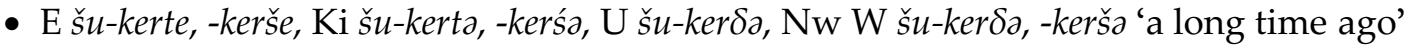

- E V merčem, B nerčem (!), U Nw W mercem 'I am unwell, sickly'

- E Ki V U Nw W ner 'nose'

- E nerye, U W nerya 'badger'

- E Nw W šer 'pearl'

- E V U šeram, Ki śeram, Nw W šeräm 'I brush'

- E V šerye, Ki U Nw W šerya 'expensive'

- E werč(an), Ki werčan, $\mathrm{V}$ werh̆č, $\mathrm{U} \mathrm{Nw} \mathrm{W}$ werc(an) 'instead of' 
Thus, there are 12 examples of $\mathrm{W}$-er- and 11 examples of $\mathrm{W}$-är-. The distinction cannot be attributed to any conditioning factor, as revealed by the minimal pair šer 'pearl' : šär 'vein' and the semiminimal pairs kerra 'woodpecker' : käryältem 'I roll up' and erra 'son' : äryem 'I coil yarn'. Thus, in this environment a contrast between Itkonen's PMari ${ }^{*} e$ and ${ }^{*} \varepsilon$ really can be established. The reconstruction of a phoneme ${ }^{*} \varepsilon$ is an unsatisfactory interpretation of this contrast, however. From a typological point of view it appears implausible that Proto-Mari possessed a phonological contrast between $/ \mathrm{e} /$ and $/ \varepsilon /$, but that this contrast was only realized before the consonant /r/ (in addition, there is the unique word kä $\delta$ a 'dove' which could perhaps be reconstructed as $\left.{ }^{*} \mathrm{k} \varepsilon \mathrm{d} \partial\right)$. Such a claim would also make it quite impossible to understand why the specific sound correspondence that ${ }^{*} \varepsilon$ is reconstructed to account for can be explained as a result of conditioned development of ${ }^{*} \mathrm{e}$ in another context, namely before a velar $\left({ }^{*} \mathrm{n}\right.$ or $\left.{ }^{*} \mathrm{k}\right)$.

On the other hand, Bereczki's (1994: 92-95) solution of reconstructing *e in place of both Itkonen's *e and * $\varepsilon$ is unacceptable, because it leaves it a mystery why *er is sometimes reflected as W $\ddot{a}$ and sometimes as W er. Importantly, W er and är have different Uralic sources, which shows that the opposition must represent an archaism. W är appears in the reflexes of Uralic *ä-stems and $\mathrm{W}$ er in the reflexes of *i-stems:

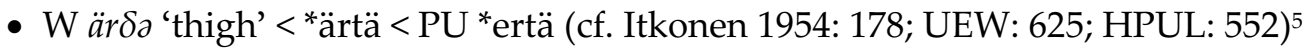

- W jär 'lake' < PU *jäwrä (UEW: 633)

- W šär 'vein' < PU *särä (UEW: 437; HPUL: 548)

- W šärtńi 'willow' < PU *särnä (UEW: 752)6

- W keräm 'I stick in' < PU *käri- (Aikio 2002: 18)

- W kerya 'woodpecker' < PU *kärki (UEW: 652)

- W kertäm 'I can, am able' < PU *kärti- (UEW: 652)

- W ner 'nose' < PU *näri (UEW: 303-304; HPUL: 552)

Hence, the opposition between $\mathrm{W}$ er and $\ddot{\text { ar }}$ must date back to Proto-Mari, but a distinct vowel phoneme ${ }^{*} \varepsilon$ is unlikely to be the source of this opposition. Instead, we can postulate the hypothesis that W är reflects PMari *er, whereas W er reflects PMari *ir. This implies that there has been a change ${ }^{*} \mathrm{i}>e$ before $r$ in all varieties of Mari. This would of course remain an ad hoc claim, were it not that two circumstances support this idea. First, there appear to be no common Mari words with the sequence $i r$. Second, the assumed change * $i>e / \_$is completely analogous with the change $* \ddot{\mathrm{u}}>\ddot{o} / \_r$, which in section 3 above was shown to have taken place in all varieties of Mari. Hence, we can assume that Proto-Mari close full front vowels ( ${ }^{*} \mathrm{i}$ and $\left.{ }^{*} \ddot{\mathrm{u}}\right)$ became lowered to mid vowels $(e$ and $\ddot{o})$ before ${ }^{*} \mathrm{r}$.

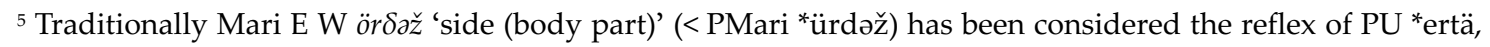
and thus cognate with Inari Saami ertti 'side', Erzya Mordvin iŕd'es 'rib', Udmurt urdes 'side' and Komi ord-li 'rib'

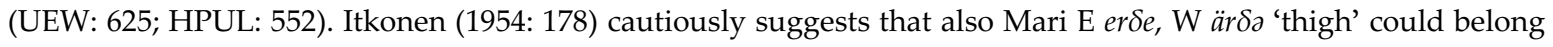
in this connection. However, there is no regular internal relationship between the Mari words for 'thigh' and 'side',

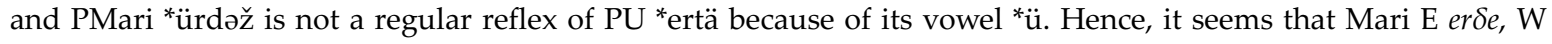
är $\delta$ ' 'thigh' is the true inherited reflex of PU *ertä, and that *ürdəž was borrowed from some other branch, probably from Pre-Proto-Permic *ördVs (> Proto-Permic *ordes).

${ }^{6} \mathrm{UEW}$ reconstructs the proto-form as *sarńe, but the front vowel in Mari W šärtńi, E V šertńe, U šertńa, Nw šerńa cannot be a reflex of PU *a. Instead, the form *särnä can be reconstructed. Finnish saarni 'ash' shows secondary back vocalism like, e.g., Finnish sappi ‘gall' (<PU *säppä) and talvi 'winter' (<PU *tälwä). The irregular back vocalic forms in some Mari varieties (B Ka šartńe, Ki sartńi šartńi) also seem to be secondary. 
There are, however, two words which seem to serve as counterevidence to the idea of a change ${ }^{*} \mathrm{i}>e / \_r$ in all varieties. In the following cases the change ${ }^{*} \mathrm{i}>e$ has occurred in $\mathrm{B} \mathrm{Ka} \mathrm{Kr}$ Ki S M V, whereas $i$ is retained in $\mathrm{U} N w \mathrm{~W}$ :

- B Kr V šere, Ki śera, M S šera, MU šire, U Nw W šira 'unleavened'

- B Ka Ki Kr S M MU ter, U Nw W tir 'sled'

These items belong to a larger group of words that appear to have undergone a change $*_{i}>e$ in all eastern varieties except for $U$ (in MU the reflexes are inconsistent, perhaps as a result of dialect borrowing):

- B Ka Kr M MU (!) S V lewa, Ki l’ewa, U liwa, Nw W liwä 'it becomes warm'

- B Ka Ki Kr M S V mež, U Nw W miž 'wool'

- B Ka Kr peçe, Ki M S peča, V peče, MU piče peč́e (!), U Nw pica, W piča 'fence'

- Ki M pemba, U pimba, W pinga (!) 'finch'

- B M S V šem, Ki śim (!), Ka (!) MU U Nw W šim 'black'

- B Ka Ki Kr M S V šen, MU U Nw W šin 'tinder'

- E ter, Ki teŕ, U Nw W tir 'sled'

- B Ka Kr M S V weleš, Ki wel'eš, MU U Nw W wileš 'it falls'

- B Ki Kr S M V wem, MU wime, U wima, Nw mima, W wim 'marrow'

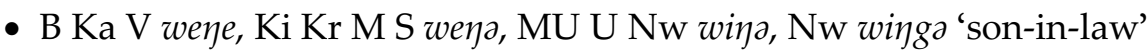

This group of words has been discussed by Itkonen (1954: 219-221), who presents cogent arguments for interpreting $i$ as the original vowel, and speaks of a "tendency" ("Neigung") of ${ }^{*}$ i to change to $e$ before the consonants $l, r$ and $m$ in eastern varieties. It is worth noting that in all cases except for peçe, peče 'fence' and mež 'wool' the following consonant is a sonorant. In contrast, however, there are only three common Mari words that are not known to be recent borrowings and that uniformly show $i$ before a sonorant:

- E W U ime, Ki Nw ima, W im 'needle'

- E imńe, Ki imńa, V ı̌mń́̆ (!), U Nw W imńi 'horse'

- E V U kinde, Ki Nw W kinda 'bread; grain'

Common Mari $i$ occurs, however, in many words before Proto-Mari obstruents:

- E V ife, U Nw W ija 'young (of animals)' (< PMari *igə)

- E Ki V U Nw W ik 'one' (<PMari *ik)

- E iksa, Ki ikś, V ikśa, U insa (!), Nw W iksä ‘small bay’ (<PMari *ikśa)

- E ize, izi, V iźi, U Nw W izi 'small' (<PMari *ićə)

- E V U iške, Ki iśka, Nw W iška 'wedge' (<PMari *iskə)

- E V U NW W kiš 'resin' (<PMari *kiš)

- E kit, (M MU) kat (!), Ki U Nw W kit, V kŭt (!) 'hand' (<PMari *kit)

- Ki S M MU U lišan, Nw W lišän 'near', B Ka Kr lašan (!) (< PMari *lišan)

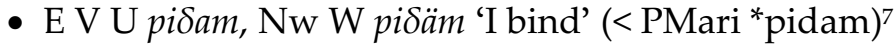

- E V U Nw W pikš, Ki pikś 'arrow' (<PMari *piks)

7 This verb seems to be an Indo-European loan: PMari ${ }^{*}$ pida- $<$ Pre-PMari ${ }^{*}$ pänti- $<$ Indo-European ${ }^{*} b^{\mathrm{h}} \mathrm{end}^{\mathrm{h}}-$ 'bind'. The suggested comparison to Hungarian füz 'laces, strings, threads' (UEW: 386) is not phonologically regular. 
- E U Nw piktem, W püktem (secondary *pi- > pü-), V pǔktem (!) 'I strangle' (<PMari *piktem)

- E pište, piste, V piste, U Nw W pišta 'linden' (<PMari * pistə)

- E Ki U Nw W piž, V pež (!) 'woolen mitten' (<PMari *piž)

- E V šište, Ki U Nw W šišta 'woodpecker' (< PMari *šištə)

- V U Nw W wiסem, E Ki wïßem (secondary *wi- > wü-) 'I take (somewhere), lead' (< PMari ${ }^{*}$ widem)

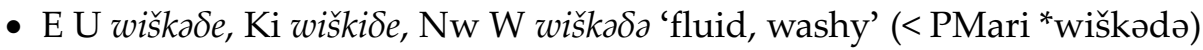

As there are six examples of lowering of ${ }^{*} i$ before sonorants in eastern varieties and only three cases showing ${ }^{*} i$ retained in the same environment, the former treatment appears to be the regular one. The lack of lowering in ime 'needle' and imne 'horse' might perhaps be explained by the fact that the vowel appears in initial position. At least ime 'needle' is very probably an old word and goes back to PU *äjmä (UEW: 22; HPUL: 536), even though one cannot completely disregard the possibility that it was borrowed from Permic (cf. Komi jem, Jazva Komi i.m 'needle' < Proto-Permic *im < PU *äjmä). Also, why the vowel was lowered in peçe, peče 'fence' and mež 'wool' lacks an explanation, but it is worth noting that mež 'wool' seems to be a Permic loanword and as such may have spread between Mari varieties: its loan original is Komi mež 'ram' (< Proto-Permic *miž < Aryan, cf. Sanskrit meșá- 'sheep, ram', Aves$\tan m a \bar{e} \check{s} a$ - 'sheep'). Bereczki (1992: 92) considers the Mari and Komi words to be independent borrowings from Aryan, but this notion lacks supporting evidence. The word peçe, peče 'fence' seems to be of Uralic origin (cf. Finnish piha 'yard', Udmurt puč, Komi poč 'stick, bar'), but the vowel correspondences between the cognates are deviant, and the proposed reconstructions *piča (UEW: 729) and *pičča (HPUL: 553) lack justification. Due to the scarcity of examples and the multiple etymological possibilities regarding some of the words, the details of the eastern Mari change $*_{i}>e$ remain rather unclear.

Let us now return to common Mari -er-. The interpretation that -er- reflects PMari *-irraises a question: why did the lowering ${ }^{*} \mathrm{i}>e / \_r$ take place only in eastern varieties in the words šere ( U Nw W šira) 'unleavened' and ter ( U Nw W tir) 'sled', but in all varieties in other words? This question cannot be given a definite answer for the time being, but we must assume that the common Mari vowel lowering ${ }^{*} \mathrm{i}>e / \_r$ is older than the eastern Mari lowering ${ }^{*} \mathrm{i}>e$ before sonorants. This implies that any new loanword with the sequence -ir- that was introduced after the first lowering would then have undergone the second lowering in eastern varieties, but not in the west. This is, indeed, confirmed by Chuvash loanwords:

- E V er, MU er ir, V Nw W ir 'morning, early' < *ir < Chuvash ir 'morning, early'

- E MU erak, V erịk, U Nw W irak 'freedom' < *irək < Chuvash irak 'freedom'

- E ser, śer, Ki śer, U Nw W sir 'shore' < śsir < Chuvash śir 'precipice, ravine, slope on a shore'

- E serem, śerem, Ki śerem, MU U Nw W sirem 'I write' < *śire- < Chuvash śir 'write'

Thus, we can speculate that also šere 'unleavened' and ter 'sled' could be loanwords from some as yet unidentified source. A Uralic etymology has been proposed for ter 'sled'; UEW (517) regards it cognate with Estonian tari 'wickerwork, basketwork', Finnish tarjat tärjät and East Khanty täras 'lathwork bottom in a type of sled', but due to irregular vowel correspondences this fails to convince. While the idea of recent loan origin of šere 'unleavened' and ter 'sled' remains a conjecture, the hypothesis put forward here explains the twelve attested cases of W -er- as regular and accounts for the fact that W -är- and -er-have distinct Uralic sources: PU *är- developed 
to PMari *-er- in *ä-stems and to PMari ${ }^{*}$-ir- in *i-stems. The cost of this explanation is that the phonological development of two words, Nw W šira 'unleavened' and tir 'sled', turns out difficult to account for.

\section{Proto-Mari *å and *o}

Itkonen (1954) reconstructs an opposition between PMari *å (> E Ki V U o, Nw W $a$ ) and *o (>o in all varieties). Bereczki (1994: 92-95) does not accept this postulated opposition, and reconstructs PMari *o for both correspondence patterns. The key reason for these different interpretations is connected with Itkonen and Bereczki's different views of the Uralic sources of the Mari vowels. Itkonen (1954: 191-195) maintains that PMari ${ }^{*} \mathrm{O}$ can reflect either PU *a or ${ }^{*} \mathrm{O}$, but PMari *å only occurs as a regular reflex of PU *a. However, his material also contains a number of exceptions to this postulated rule, which he explains away as results of "sporadic" developments. As noted by Bereczki (1994: 93), this position is untenable: because Itkonen's PMari *å and *o both occur as reflexes of PU *a and *o alike, Itkonen's account of the development of these PU vowels in Mari is inadequate. Even though Bereczki is right in pointing this out, his reasoning is faulty, too: it does not follow from this that the reconstruction of an opposition between PMari *å and *o is incorrect.

A major problem is that Bereczki (1994) postulates no conditioning factors that would account for the distribution of Nw W $a$ and $o$ as reflexes of his reconstructed PMari ${ }^{*} \mathrm{O}$. Numerous semiminimal pairs, such as the following, demonstrate that no such conditioning factors can be established:

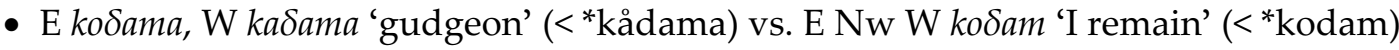

- E oškal, W aškâl 'step' (< *åškəl) vs. E oško, W oškâ 'poplar' (<*oškə)

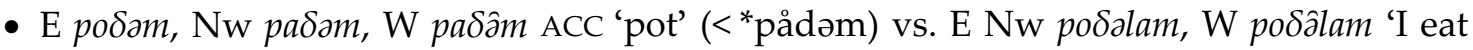
with a spoon' (<*podəlam)

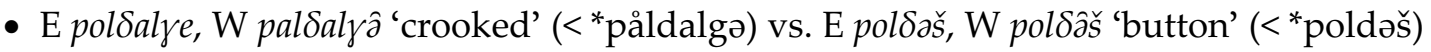

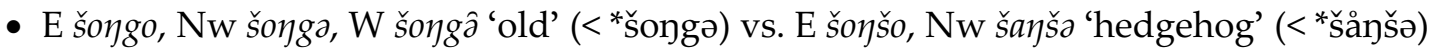

Hence, there seems to be no viable alternative to reconstructing an opposition between PMari *å and *o. It ought to be noted, however, that the distribution of PMari *a and *o seems to show clear tendencies based on the consonant environment, even though these tendencies do not amount to absolute rules. Judging from the material in TschWb, PMari *å tends to occur after initial glides $\left({ }^{*} \mathrm{w},{ }^{*} \mathrm{j}\right)$ and before the coronal consonants ${ }^{*}{ }^{*},{ }^{*}{ }^{*},{ }^{*} \mathrm{t},{ }^{*} \mathrm{~d},{ }^{*} \mathrm{r}$ and ${ }^{*} \mathrm{n}$. PMari ${ }^{*} \mathrm{o}$, in turn, is much more common before velars $\left({ }^{*} k,{ }^{*} y\right)$. These distributional tendencies probably reflect the phonological conditions that once caused a single Pre-Proto-Mari vowel to split into PMari *å and ${ }^{*} \mathrm{O}$, but a further examination of the issue is beyond the scope of this paper.

\section{Proto-Mari *a and *ä}

Itkonen (1954: 185-188, 203-207) assumes that Proto-Mari *a is uniformly preserved as $a$ in the Mari varieties, whereas the correspondence E Ki V U $a \sim \mathrm{Nw}$ W $\ddot{a}$ reflects a distinct Proto-Mari vowel *ä. According to Bereczki (1994: 88-92), however, both correspondences reflect an original *a, and there has been a sound change *a $>\ddot{a}$ in Nw and W. His argument for this interpretation is that Nw W ä can correspond to foreign *a in loanwords: e.g., E waraš, V U warakš, Nw wäräkšs, W wäräš 'hawk' < Proto-Permic *varišs (> Komi and Udmurt varišs 'hawk'). 
The problem with this interpretation is that Bereczki postulates no conditions under which the assumed change PMari *a $>\mathrm{Nw}$ W $\ddot{a}$ would have taken place. An examination of the relevant lexical data in $\mathrm{TschWb}$ reveals that no conditions can be postulated, as illustrated by the following examples.

PMari *ašk-:

- E Ki V U Nw W paškar 'small block of wood, plug' (< PMari *paškar)

- E raskalta, raškalסa, Ki raskalta, V U Nw W raškalta '(lightning) strikes' (< PMari *raškalta)

PMari *äšk-:

- E Ki V U laška, Nw W läškä 'noodle' (< PMari *läška)

- E U šaške, Nw W šäška 'otter' (<PMari *šäškə)

The initial consonants do not serve as conditioning factors, as there are also examples of PMari *pä-, ${ }^{*}$ la- and *̌sa-:

- E Ki V parča, U parca, Nw W pärcä 'ear of corn' (< PMari *pärća) ${ }^{8}$

- E U laštartem, Ki laštirtem 'I crush into pieces', W laštârtem 'I splinter (wood)' (< PMari *laštərtem)

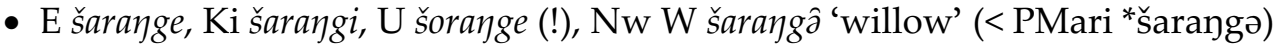

Hence, an application of the comparative method leaves no alternative to reconstructing two Proto-Mari phonemes: *a and *ä. How the vowel substitution patterns observed in loanwords that Bereczki brings up are to be explained is a complex question which cannot be addressed in the present study. It must be noted, however, that it is not justified to mechanically interpret sound correspondences in loanwords so that if the donor form contains an *a, then this sound also must have been adopted as an *a in the recipient language. Sound substitutions are influenced by a multitude of factors, including phonological and allophonic differences between the contacting languages and rival sound substitution strategies based on conflicting phonetic, etymological and systemic motives (Aikio 2007).

\section{Conclusion}

The main results of this study can be summarized as follows:

a) As maintained by Itkonen (1954), the initial-syllable reduced vowels in Mari varieties clearly go back to Proto-Mari vowel phonemes that were distinct from the source of Northwest and West Mari close full vowels $i$, $\ddot{u}$ and $u$. Thus, two series of close vowels must be postulated for Proto-Mari: ${ }^{*} \mathrm{i},{ }^{*} \ddot{\mathrm{u}},{ }^{*} \mathrm{u}$ vs. ${ }^{*} \mathrm{u},{ }^{*} \breve{\mathrm{u}},{ }^{*} \breve{\mathrm{u}}$. The alternative view of Bereczki (1994) that reduced vowels developed from full vowels through irregular sound change motivated by extensive Turkic influence is untenable, because this assumption does not account for the regular vowel correspondences between the Mari varieties, and because reduced and full close vowels can be shown to have distinct Uralic sources.

b) The original distinctive factor between Proto-Mari ${ }^{*} i,{ }^{*} \ddot{\mathrm{u}},{ }^{*} \mathrm{u}$ and ${ }^{*} \breve{1},{ }^{*} \breve{\mathrm{u}}$, ${ }^{*} \breve{\mathrm{u}}$ was not necessarily full vs. reduced articulation. It is likely that the opposition became phonetically

${ }^{8}$ PMari *pärća is apparently a loan from some Iranian source, cf. Young Avestan parša- 'ear of corn', Sanskrit parșá- 'sheaf, bundle'. 
restructured as such under the influence of Turkic languages. The original distinctive factor could also have been length or height, or a combination of these features.

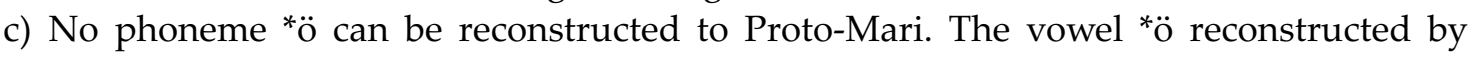
both Itkonen (1954) and Bereczki (1994) can be interpreted as an allophone of ProtoMari ${ }^{*} \ddot{\mathrm{u}}$; there has been a regular change ${ }^{*} \ddot{\mathrm{u}}>\ddot{o}$ before ${ }^{*} \mathrm{r}$ in all Mari varieties.

d) As maintained by Itkonen (1954; contra Bereczki 1994), a phonological opposition between PMari *å (> E $o, \mathrm{Nw} \mathrm{W} \mathrm{a)} \mathrm{and} \mathrm{*o} \mathrm{(>} \mathrm{E} \mathrm{Nw} \mathrm{W} \mathrm{o)} \mathrm{must} \mathrm{be} \mathrm{reconstructed;} \mathrm{the} \mathrm{occur-}$ rence of both Nw W $a$ and $o$ as correspondents of $\mathrm{E} o$ cannot be attributed to any conditioning factors. However, contrary to what is claimed by Itkonen (1954), the PMari opposition *å : ${ }^{*}$ does not appear to be a continuation of the Proto-Uralic opposition ${ }^{*} \mathrm{a}:{ }^{*} \mathrm{o}$.

e) As maintained by Bereczki (1994; contra Itkonen 1954), no Proto-Mari vowel phoneme ${ }^{*} \varepsilon$ needs to be reconstructed to account for the correspondence E Nw $e \sim \mathrm{W} \ddot{a}$. The open vowel in $\mathrm{W}$ is a result of sound change ${ }^{*} \mathrm{e}>\ddot{a}$ that took place 1) before velars, 2) before $r$, and 3) in CV-type stems.

f) In cases where $\mathrm{W}$ e occurs before $r$, Proto-Mari ${ }^{*} \mathrm{i}$ must be reconstructed (contra Bereczki 1994). There appears to have been a change ${ }^{*} i>e$ before ${ }^{*} r$ in all varieties of Mari.

g) As maintained by Itkonen (1954; contra Bereczki 1994), a Proto-Mari vowel *ä must be reconstructed to account for the correspondence $\mathrm{E} a \sim \mathrm{Nw} \mathrm{W} \ddot{a}$.

On the basis of these results we can postulate the vowel inventory shown in Table 7 for Proto-Mari initial syllables. The regular reflexes of the Proto-Mari initial syllable vowels in the Mari varieties are shown in Table 8.

On a more general level, the results of the present study provide an example of how the development of vowel systems in the Uralic languages can - and should - be explained as an effect of regular sound change. In the field of Uralic comparative linguistics there has been an unfortunate tradition of resorting to 'sporadic' changes to explain the data that do not conform to some preconceived view of historical phonology. In the case of Mari this is most conspicuous in the work of Bereczki (1994), who operates with wholesale irregular change that is assumed to have affected individual word-roots on a random basis. However, also Itkonen's (1954) attempt to account for the Uralic background of Mari vocalism frequently evokes the mysterious force of 'sporadic' change to explain away those parts of data that are incompatible with his own reconstruction of Uralic vocalism.

Thus, the notion of 'sporadic' sound change is a source of ad hoc hypotheses whose methodological purpose seems to be to avoid addressing flaws in theory: 'sporadic' changes are brought to account for those regular sound correspondences that lack an explanation in the framework of Uralic historical phonology endorsed by the author. However, if regular sound correspondences are thought to result from both regular and irregular change, the basis for a consistent application of the comparative method is lost. Hence, the alleged instances of 'sporadic' change should rather be viewed as indicators of weak points in theories of Uralic historical phonology. An essential task for future research in comparative Uralic linguistics is to examine whether regular accounts of supposedly 'sporadic' phonological developments can be provided, and the explanatory power of theories of Uralic historical phonology increased accordingly. 
Table 7. The Proto-Mari initial syllable vowels.

\begin{tabular}{|c|c|c|c|}
\hline $\mathrm{i}$ & $\ddot{\mathrm{u}}$ & & $\mathrm{u}$ \\
\hline$\breve{1}$ & $\breve{\mathrm{u}}$ & & $\breve{\mathrm{u}}$ \\
\hline $\mathrm{e}$ & & & $\mathrm{O}$ \\
\hline ä & & $a$ & å \\
\hline
\end{tabular}

Table 8. The reflexes of Proto-Mari initial syllable vowels in the Mari varieties.

\begin{tabular}{|c|c|c|c|c|c|c|}
\hline Proto-Mari & $\mathrm{E}$ & $\mathrm{Ki}$ & $\mathrm{V}$ & $\mathrm{U}$ & $\mathrm{Nw}$ & W \\
\hline *ä & a & $\mathrm{a}$ & a & a & $\ddot{a}$ & ä, $\mathrm{e}^{1}$ \\
\hline *e & e & e & $\mathrm{e}$ & $\mathrm{e}$ & e & $\mathrm{e}, \ddot{\mathrm{a}}^{2}$ \\
\hline$*_{i}$ & $\mathrm{i}, \mathrm{e}^{3}$ & $\mathrm{i}, \mathrm{e}^{3}$ & $\mathrm{i}, \mathrm{e}^{3}$ & $\mathrm{i}, \mathrm{e}^{4}$ & $\mathrm{i}, \mathrm{e}^{4}$ & $\mathrm{i}, \mathrm{e}^{4}$ \\
\hline$* \ddot{\mathrm{u}}$ & $\ddot{\mathrm{u}}, \ddot{\mathrm{o}}^{5}$ & ü, $\ddot{\mathrm{o}}^{5}$ & $\ddot{\mathrm{u}}, \ddot{\mathrm{o}}^{5}$ & $\ddot{\mathrm{u}}, \ddot{\mathrm{o}}^{5}$ & $\ddot{\mathrm{u}}, \ddot{\mathrm{o}}^{6}$ & $\ddot{\mathrm{u}}, \ddot{\mathrm{o}}^{6}$ \\
\hline$* a$ & a & a & a & a & a & $\mathrm{a}$ \\
\hline *å & o & o & $\mathrm{o}$ & $\mathrm{o}$ & $\mathrm{a}$ & a \\
\hline$*_{\mathrm{O}}$ & $\mathrm{o}, \mathrm{u}^{7}$ & $\mathrm{o}, \mathrm{u}^{7}$ & $\mathrm{o}, \mathrm{u}^{7}$ & $\mathrm{o}, \mathrm{u}^{7}$ & $\mathrm{o}, \mathrm{u}^{7}$ & $\mathrm{o}$ \\
\hline${ }^{*} \mathrm{u}$ & $\mathrm{u}$ & $\mathrm{u}$ & $\mathrm{u}$ & $\mathrm{u}$ & $\mathrm{u}$ & $\mathrm{u}$ \\
\hline$*_{1}$ & $\partial, \mathrm{i}^{8}$ & $\mathrm{i}$ & ә & $\breve{1}$ & ә & ә \\
\hline$* \breve{u}$ & $\ddot{\mathrm{u}}$ & $\ddot{\mathrm{u}}$ & $\breve{\mathrm{u}}$ & $\breve{\mathrm{u}}, \ddot{\mathrm{u}}^{9}$ & $\breve{\mathrm{u}}$ & ə \\
\hline$* \breve{\mathrm{u}}$ & $\mathrm{u}$ & $\mathrm{u}$ & $\breve{\mathrm{u}}$ & $\breve{\mathrm{u}}$ & $\breve{~ o ̆}$ & $\hat{\partial}$ \\
\hline
\end{tabular}

Notes:

${ }^{1} e$ before ${ }^{*} \mathrm{j}$

$2 \ddot{a}$ before a velar or ${ }^{*} \mathrm{r}$ and in ${ }^{*} \mathrm{CV}$-type roots

${ }^{3} e$ before sonorants, except in word-initial position (?)

$4 e$ before ${ }^{*} \mathrm{r}$

${ }^{5} \ddot{O}$ before ${ }^{*} \mathrm{r}$ and between a coronal sonorant and a coronal continuant (not $\delta$ )

${ }^{6} \ddot{o}$ before ${ }^{*} \mathrm{r}$

${ }^{7} u$ word finally and before a hiatus

$8 i$ before the cluster *ńć, and in B Ka Kr also before *ć

${ }^{9}$ usually $\breve{u}$, but numerous exceptional forms with $\ddot{u}$ are attested

\section{Abbreviations for Mari varieties}

\begin{tabular}{|c|c|c|c|c|c|c|}
\hline Birsk & $\mathrm{Ki}$ & Bolshoj Kil'mez & MU & Mari-Ushem & V & Volga \\
\hline East (any of the va- & $\mathrm{Ka}$ & Kaltasy & $\mathrm{Nw}$ & Northwest & W & West \\
\hline rieties B Ka Kr M & $\mathrm{Kr}$ & Krasnoufimsk & S & Sernur & & \\
\hline MU S) & M & Morki & $\mathrm{U}$ & Upsha & & \\
\hline
\end{tabular}

\section{Literature}

AIKIO, Ante 2002. New and Old Samoyed Etymologies. Finnisch-Ugrische Forschungen 57: 9-57.

AIKIO, Ante 2006. New and Old Samoyed Etymologies (Part 2). Finnisch-Ugrische Forschungen 59: 9-34.

AIKIO, Ante 2007. Etymological Nativization of Loanwords: a Case Study of Saami and Finnish. In: Ida TOIVONEN \& Diane Nelson (eds.), Saami linguistics. Amsterdam \& Philadelphia: John Benjamins. Pp. 17-52.

AIKIO, Ante 2012. On Finnic long vowels, Samoyed vowel sequences and Proto-Uralic *x. In: Tiina HYYTIÄINEN,

Lotta JALAVA, Janne SAARIKIVI \& Erika SANDMAN (eds.), Per Urales ad Orientem: Iter polyphonicum multilingue. 
Festskrift tillägnad Juha Janhunen på hans sextioårsdag den 12 februari 2012. Mémoires de la Société FinnoOugrienne 264: 227-250.

AIKIO, Ante (forthcoming). Studies in Uralic etymology III: Mari etymologies.

BERECZKI, Gábor 1988. Geschichte der wolgafinnischen Sprachen. In: Denis SINOR (ed.), The Uralic languages. Description, history and foreign influences, pp. 314-350. Leiden \& New York \& København \& Köln: E.J. Brill.

BERECZKI, Gábor 1992. Grundzüge der tscheremissischen Sprachgeschichte II. Studia Uralo-Altaica 34. Szeged.

BERECZKI, Gábor 1994. Grundzüge der tscheremissischen Sprachgeschichte I. Studia Uralo-Altaica 35. Szeged.

HONTI, László 1984: Chrestomathia Ostiacica. Budapest: Tankönyvkiadó.

HPUL = SAMMALLAHTI, Pekka 1988. Historical phonology of the Uralic languages with special reference to Samoyed, Ugric and Permic. In: Denis SINOR (ed.), The Uralic languages. Description, history and foreign influences, pp. 478-554. Leiden \& New York \& København \& Köln: E.J. Brill.

ITKONEN, Erkki 1954. Zur Geschichte des Vokalismus der ersten Silbe im Tscheremissischen und in den permischen Sprachen. In: Finnisch-Ugrische Forschungen 31: 149-345.

RÄSÄNEN, Martti 1920. Die tschuwassischen Lehnwörter im Tscheremissischen. Mémoires de la Société Finno-ougrienne 48. Helsinki: Société Finno-ougrienne.

SALMINEN, Tapani 2007. Notes on Forest Nenets phonology. In: Jussi YliKOSKI \& Ante AIKIO (eds.), Sámit, sánit, sátnehámit. Riepmočála Pekka Sammallahtii miessemánu 21. beaivve 2007. Mémoires de la Société Finno-Ougrienne 253. Pp. 349-372.

SEbeoK, Thomas A. \& Ingermann, Frances J. 1961. An Eastern Cheremis Manual: Phonology, Grammar, Texts, Glossary. Indiana University Publications, Uralic and Altaic Series vol. 5. Bloomington: Indiana University.

SSA = Erkki ITKONEN \& Ulla-Maija KULONEN (eds.) 1992-2000. Suomen sanojen alkuperä. Etymologinen sanakirja. Helsinki: Kotimaisten kielten tutkimuskeskus \& Suomalaisen kirjallisuuden seura.

TschWb = MOISIO, Arto \& SAARINEN, Sirkka 2008. Tscheremissisches Wörterbuch. Aufgezeichnet von Volmari Porkka, Arvid Genetz, Yrjö Wichmann, Martti Räsänen, T. E. Uotila und Erkki Itkonen. Lexica Societatis FennoUgricae XXXII. Helsinki: Suomalais-ugrilainen seura \& Kotimaisten kielten tutkimuskeskus.

UEW = RÉDEI, Károly 1988-1991. Uralisches Etymologisches Wörterbuch. Budapest: Akadémiai Kiadó.

Appendix A. Correspondences of reduced vowels between Mari varieties

This Appendix includes lists of those Proto-Mari word-roots for which Proto-Mari * ${ }_{\mathfrak{1}}$ * $\breve{\mathrm{u}}$ or *ŭ can be reconstructed according to Itkonen's (1954) system of Proto-Mari vocalism. For each word, the reflexes of the first syllable vowel in the Mari varieties documented in TschWb are given. Reflexes judged irregular appear underlined and in bold font weight.

\begin{tabular}{|c|c|c|c|c|c|c|c|c|c|c|c|}
\hline Proto-Mari ${ }^{*}{ }^{\mathbf{1}}$ : & B & $\mathbf{K r}$ & $\mathbf{K a}$ & $\mathbf{K i}$ & $S$ & $\mathbf{M}$ & MU & $\mathbf{U}$ & V & Nw & $\mathbf{W}$ \\
\hline *ćíćə 'nipple' & $\mathrm{i}$ & $\underline{\mathbf{u}}$ & $\mathrm{i}$ & $\mathrm{i}$ & ə, $\underline{\mathbf{i}}$ & ə, $\underline{\mathbf{i}}$ & ə, $\underline{\mathbf{i}}$ & ә & $\breve{1}$ & ә & ә \\
\hline *ćígəlte- 'tickle' & ә & $\partial$ & ә & $\mathrm{i}$ & ә & ə & & & $\breve{1}$ & ə & ə \\
\hline *ćílä 'all' & ә & ə & ә & $\mathrm{i}$ & ә & ə & ə & ə & $\breve{1}$ & ə & $\underline{\mathbf{i}}$ \\
\hline *ćirkəne- 'hurry' & ә & & & & & & & ә & & ə & ә \\
\hline *ćíwəlte- 'bathe' & ә & & ә & & ə & ә & & ә & $\breve{1}$ & ә & ә \\
\hline *ćīwəšte- 'pinch' & ə & ə & ә & $\mathrm{i}$ & ə & $\partial$ & & $\underline{\mathbf{i}}$ & & $\underline{\mathbf{i}}$ & ə \\
\hline *ćĭwətan 'pinchers' & ә & ə & & $\mathrm{i}$ & & ə & & ə & $\breve{1}$ & ə & ә \\
\hline *čĭme- 'stretch' & ә & ə & ә & i & ә & ә & & $\underline{\ddot{\mathrm{u}}}$ & $\underline{\breve{\mathrm{u}}}$ & ә & ә \\
\hline *úća 'older brother' & $\mathrm{i}$ & $\mathrm{i}$ & $\mathrm{i}$ & $\mathrm{i}$ & $\underline{\mathbf{i}}$ & $\underline{\mathbf{i}}$ & $\underline{\mathbf{i}}$ & ә & $\breve{1}$ & ə & ə \\
\hline *lle- 'live' & $\underline{\mathbf{i}}$ & $\underline{\mathbf{i}}$ & $\underline{\mathbf{i}}$ & $\mathrm{i}$ & $\underline{\mathbf{i}}$ & $\underline{\mathbf{i}}$ & $\underline{\mathbf{i}}$, ә & ә & $\breve{1}$ & ə & ə \\
\hline *ĭndəðšə 'nine' & $\underline{\mathbf{i}}$ & $\underline{\mathbf{i}}$ & $\underline{\mathbf{i}}$ & $\mathrm{i}$ & $\underline{\mathbf{i}}$ & $\underline{\mathbf{i}}$ & $\underline{\mathbf{I}}$ & ә & $\breve{1}$ & $\underline{\breve{\mathrm{u}}}$ & ә \\
\hline *1̌rwećə 'young' & ә & $\underline{\emptyset}$ & ә & $\underline{\mathbf{u}}$ & ә & $\partial, \underline{\emptyset}$ & ə & $\underline{\emptyset}$ & $\breve{1}$ & ә & ә \\
\hline
\end{tabular}




\begin{tabular}{|c|c|c|c|c|c|c|c|c|c|c|c|}
\hline Proto-Mari *̌̃: & B & $\mathbf{K r}$ & $\mathrm{Ka}$ & $\mathbf{K i}$ & $S$ & $\mathbf{M}$ & MU & $\mathbf{U}$ & $\mathbf{V}$ & Nw & $\mathbf{W}$ \\
\hline *1ške (reflexive pronoun) & $\underline{\emptyset}$ & ә, $\underline{\emptyset}$ & $\underline{\emptyset}$ & $\mathrm{i}$ & $\underline{\emptyset}$ & $\partial, \underline{\emptyset}$ & $\underline{\emptyset}$ & $\underline{\emptyset}$ & $\underline{\emptyset}$ & $\underline{\emptyset}$ & $\underline{\emptyset}$ \\
\hline *ǔšte- 'make, do' & ә & & ә & & ә & ә & ә & ә & $\breve{1}$ & ә & ә \\
\hline * 1štər 'footwrap' & ә & ә & ә & $\mathrm{i}$ & ә & ә & ә & ә & $\breve{1}$ & ә & ә \\
\hline *jǐče- 'hurt' & ә & & & $\mathrm{i}$ & ә & ә & & ә & $\breve{1}$ & ә & ә \\
\hline *jǐčke- 'pick, pluck' & & & & $\mathrm{i}$ & & & & & $\breve{1}$ & ә & $\partial$ \\
\hline *jǔčkəšte- 'get dislocated' & ә & & & $\mathrm{i}$ & ә & ә & & ә & & ә & $\partial, \breve{1}$ \\
\hline *jĭdan 'bowstring' & ә & & ә & $\mathrm{i}$ & & ә & & ә & & ә & $\partial$ \\
\hline *jĭde 'every' & $\underline{\mathbf{i}} \underline{\mathbf{e}}$ & & ә & & $\underline{\mathbf{e}}$ & $\underline{\mathbf{e}}$, ә & $\partial$ & ә & $\breve{1}$ & ә & $\partial, \breve{1}$ \\
\hline *jĭdəm 'threshing floor' & $\underline{\mathbf{i}}$ & $\underline{\mathbf{i}}$ & $\underline{\mathbf{i}}$ & $\mathrm{i}$ & $\underline{\mathbf{i}}$ & $\underline{\mathbf{i}}$ & ә & ә & $\breve{1}$ & ә & ә \\
\hline *jĭgəlta- 'mock' & $\underline{\mathbf{i}}$ & & & $\mathrm{i}$ & $\underline{\mathbf{i}}$ & & & & $\breve{1}$ & & ә \\
\hline *jĭgəžge- 'be disgusted' & ә & & ә & $\mathrm{i}$ & ә & $\partial$ & ә & ә & $\breve{1}$ & & \\
\hline *jūl 'earthworm' & ә & $\partial, \underline{\mathbf{e}}$ & & $\mathrm{i}$ & $\partial$ & ə & ә & ә & & ә & $\partial, \breve{1}$ \\
\hline *jĭle 'quick, soon' & ә & ә & & $\mathrm{i}$ & & & & ә & & ә & ә \\
\hline *jūlgəža- 'shine, glitter' & ә & ә & & $\breve{1}$ & ә & ә & & ә & $\breve{1}$ & ә & $\partial, \breve{1}$ \\
\hline *jülmə 'tongue' & ə & ә & ә & $\underline{\ddot{u}}$ & ә & ә & ә & ә & & ə, $\breve{1}$ & $\partial, \breve{1}$ \\
\hline *jǔlt 'entirely' & ә & & & & ә & ә & & ә & $\breve{1}$ & $\partial, \underline{\mathbf{o}}$ & $\breve{1}$ \\
\hline *jĭme- 'go numb' & ә & ә & ә & i & ә & ә & & ә & $\breve{1}$ & ә & ә \\
\hline *jĭnəśe- 'whimper' & $\partial, \underline{\mathbf{e}}$ & & & $\underline{\mathbf{e}}$ & ә & ә & & ә & & & $\breve{1}$ \\
\hline *jĭngəl/r 'bell' & $\partial, \underline{\mathbf{o}}$ & & & & & ә & & & & ә & $\partial, \breve{1}$ \\
\hline *jĭp 'spark' & & & & & ә & & ә & $\underline{\ddot{\mathbf{u}}}$ & & $\underline{\mathbf{i}}$ & $\underline{\mathbf{i}}$ \\
\hline *jĭpš 'spear, sharp stick' & ә & ә & & $\mathrm{i}$ & & & ә & ә & & & $\breve{1}$ \\
\hline *jĭr 'around' & ә & ә & ә & $\breve{1}$ & ә & ә & ә & ә & $\breve{1}$ & ә & ә \\
\hline *jĭwəžge 'still, quiet' & & & & & ә & ә & & ә & & ә & $\partial$ \\
\hline *jǐžən 'joint' & ә & ә & ә & $\breve{1}$ & ә & ә & ә & ә & $\breve{1}$ & ә & $\underline{\mathbf{e}}$ \\
\hline *jǔžge 'quiet, slow' & ә & & & & ә & ә & & $\underline{\breve{\mathbf{u}}}$ & & ә & \\
\hline *kǐćət 'now' & $i, \underline{\text { o }}$ & $\mathrm{i}$ & & $\mathrm{i}$ & ә & $\partial$ & ә & ә & & ә & ə \\
\hline *kíćke- 'harness' & $\mathrm{i}, \underline{\mathrm{a}}$ & $\mathrm{i}$ & $\mathrm{i}$ & $\mathrm{i}$ & $\underline{\mathbf{i}}$, ə & ә & ә & ә & $\breve{1}$ & $\partial$ & ә \\
\hline *kǐćkə 'seed' & $\mathrm{i}$ & $\mathrm{i}$ & $\mathrm{i}$ & $\mathrm{i}$ & $\underline{\mathbf{i}}$ & ә & ә & ә & $\breve{1}$ & ә & ә \\
\hline *kǐčala- 'search' & ә & ә & ә & $\mathrm{i}$ & ә & ә & ә & ә & $\breve{1}$ & ә & ә \\
\hline *kǐčək, *kǐča 'fresh, fine snow' & ә & ә & & $\breve{1}$ & ә & ә & ә & ә & $\breve{1}$ & ә & ә \\
\hline *kĭdal 'waist' & ә & $\partial$ & ә & $\mathrm{i}$ & ә & ә & $\partial$ & ә & $\breve{1}$ & ә & ә \\
\hline *kĭdež 'room' & ә & & & $\mathrm{i}$ & ә & ә & ә & ә & $\breve{1}$ & ә & ә \\
\hline *kĭl'akšs ‘best linen fibers' & $\underline{\ddot{\mathbf{u}}}$ & $\underline{\mathrm{u}}$ & $\underline{\ddot{\mathbf{u}}}$ & $\underline{\mathrm{u}}$ & $\underline{\mathrm{u}}$ & ә & ә & ә & $\breve{1}$ & ә & ә \\
\hline *kĭlde- 'bind' & ә & ә & ә & i & ә & ә & ә & ә & $\breve{1}$ & ә & $\partial$ \\
\hline *kĭləmdə 'navel' & ә & ә & ә & $\mathrm{i}$ & ә & ә & ә & ә & $\breve{1}$ & ә & ә \\
\hline *kǐlmə 'cold' & ә & ә & & $\mathrm{i}$ & $\partial$ & ә & ә & ә & $\breve{1}$ & ә & ә \\
\hline *kǐńe 'hemp' & ә & & & $\mathrm{i}$ & ә & ә & ә & ә & $\breve{1}$ & $\partial$ & ә \\
\hline $\begin{array}{l}\text { *kíńela- 'stand up, rise, wake } \\
\text { up' }\end{array}$ & ә & & & $\mathrm{i}$ & ә & ә & ә & ә & $\breve{1}$ & ә & ә \\
\hline *kǐńer 'ell' & ә & & & $\mathrm{i}$ & ә & ә & ә & ә & $\breve{1}$ & ә & ә \\
\hline
\end{tabular}




\begin{tabular}{|c|c|c|c|c|c|c|c|c|c|c|c|}
\hline Proto-Mari *̌i: & B & $\mathbf{K r}$ & Ka & $\mathbf{K i}$ & $S$ & $\mathbf{M}$ & MU & $\mathbf{U}$ & $\mathbf{V}$ & Nw & $\mathbf{W}$ \\
\hline *kĭre- 'hit' & ә & ә & ә & $\mathrm{i}$ & ә & $\partial$ & & $\underline{\emptyset}$ & $\breve{1}, \underline{\emptyset}$ & ә & $\partial$ \\
\hline *kŭrəkšs 'ruffe' & & & & & & & ә & ә & & ә & ә \\
\hline *kĭrme- 'grab' & & & & $\breve{1}$ & ә & ә & & ә & $\breve{1}$ & ә & ә \\
\hline *kǐša 'track' & ә & $\underline{\mathbf{i}}$ & ә & $\mathrm{i}$ & $\underline{\mathbf{i}}$ & ə & ә & ә & $\breve{1}$ & $\underline{\mathbf{i}}$ & $\underline{\mathbf{i}}$ \\
\hline *kǐśoja 'great tit' & $\underline{\mathbf{i}}$ & $\underline{\mathbf{i}}$ & $\underline{\mathbf{i}}$ & $\mathrm{i}$ & $\underline{\mathbf{i}}$ & $\underline{\mathbf{i}}$ & & ә & $\underline{\emptyset}$ & ә & $\partial$ \\
\hline *kiškar 'swift (for yarn)' & ə & $\partial$ & ә & $\mathrm{i}$ & ə & ə & ә & ә & $\breve{1}$ & ә & ə \\
\hline *kiške- 'throw' & ә & $\partial$ & ә & $\mathrm{i}$ & ә & ә & $\partial$ & ә & $\breve{1}$ & ә & ә \\
\hline *kǐškə 'snake' & $\underline{\mathbf{i}}$ & $\underline{\mathbf{i}}$ & $\underline{\mathbf{i}}$ & $\mathrm{i}$ & $\underline{\mathbf{i}}$ & $\underline{\mathbf{i}}$ & $\partial, \underline{\mathbf{i}}$ & ә & $\breve{1}$ & ә & ә \\
\hline $\begin{array}{l}\text { *kiškə-wuj *kǐškə-wi } \\
\text { 'cowry' }\end{array}$ & ә & & & $\mathrm{i}$ & ә & ә & ә & ә & $\breve{1}$ & ә & ә \\
\hline *lı̆gə 'scale' & ә & $\underline{\mathbf{i}}$ & $\underline{\mathbf{i}}$ & $\mathrm{i}$ & ә & $\partial$ & ә & ә & $\breve{1}$ & ә & $\partial$ \\
\hline *lïn 'much, very' & ә & ә & & & ә & ә & & ә & & ә & \\
\hline *lip/wə 'butterfly' & & & & & ә & ә & ә & ә & $\breve{1}$ & $\underline{\breve{\mathrm{u}}}$ & ә \\
\hline *lištaš 'leaf' & ә & ә & & $\mathrm{i}$ & ә & ә & ә & ә & $\breve{1}$ & ә & ә \\
\hline *lǐšte- 'make, do' & & ә & & $\mathrm{i}$ & ә & & & ә & & ә & \\
\hline *lǐwərgə 'flexible' & ә & & & $\mathrm{i}$ & ә & ə & ә & $\partial, \underline{\mathbf{u}}$ & $\breve{1}$ & $\underline{\underline{\mathbf{o}}}$ & $\underline{\hat{\mathbf{o}}}$ \\
\hline *lǐwəžge- 'wilt' & ә & ә & $\partial$ & $\mathrm{i}$ & ә & ә & ә & ә & $\breve{i}$ & ә & ә \\
\hline *lǔžga ‘mild, calm' & & & & $\breve{1}$ & ә & ә & & ә & $\breve{1}$ & ə, $\underline{\breve{\mathbf{u}}}$ & ә \\
\hline *mǐn'/jə 'I' & ə, $\underline{\mathbf{i}}$ & $\underline{\mathbf{i}}, \underline{\mathbf{e}}, \underline{\mathbf{o}}$ & $\underline{\mathbf{i}}$ & $\mathrm{i}$ & ә & ә & ә & ә & $\breve{1}$ & $\breve{1}$ & $\partial, \breve{1}$ \\
\hline *mĭndər 'happy' & & & & & & & & ә & $\breve{1}$ & & ә \\
\hline *mǐžar 'coat' & ә & ә & ә & i & ә & ә & ә & ә & $\breve{1}$ & ə, & ә \\
\hline *nĭl ‘four' & ә & ә & $\underline{\mathbf{i}}$ & $\mathrm{i}$ & ә & ә & ә & ә & $\underline{\boldsymbol{\theta}}, \breve{\mathrm{l}}$ & $\partial$ & ә \\
\hline *nǔžəlgə 'mild, soft' & ә & & ә & & ә & & ә & ә & & ә & ә \\
\hline *ńíćəlge- 'get scratched (skin)' & $\underline{\mathrm{z}}$ & & $\underline{\mathrm{z}}$ & & & & & & $\breve{1}$ & & ə \\
\hline *ńĭgəlge- 'get scratched (skin)' & ә & & & i & ә & ә & & ә & $\breve{1}$ & & ә \\
\hline *ńňkta- 'skin' & ә & & ә & $\mathrm{i}$ & ә & $\partial, \underline{\mathbf{e}}$ & ә & $\underline{\mathbf{i}}$ & $\breve{1}$ & $\underline{\mathbf{i}}$ & ә \\
\hline *ńĭmərge- 'get squashed' & ә & & & & ә & & & ә & $\breve{1}$ & & ә \\
\hline *piće- 'adhere' & $\underline{\mathrm{\theta}}$ & & & $\mathrm{i}$ & ә & ә & & ә & & ә & \\
\hline *pǔćə 'meat' & $\mathrm{i}$ & & & & $\underline{\mathbf{i}}$, ə & ә & ә & ә & & ә & \\
\hline *pǔćəre- 'squeeze' & $\underline{\partial}, \mathrm{i}$ & $\underline{\boldsymbol{\theta}}, \mathrm{i}$ & $\mathrm{i}$ & $\mathrm{i}$ & ə & ә & ә & ә & $\breve{1}$ & ә & ә \\
\hline *pǐćlə, *pǔćəlmə 'rowan' & $\underline{\underline{\partial}}, \mathrm{i}$ & $\mathrm{i}$ & $\mathrm{i}$ & $\mathrm{i}$ & ə, $\underline{\mathbf{i}}$ & $\underline{\mathbf{i}}$ & ә & ә & & $\mathrm{i}$ & ә \\
\hline *pǐčək 'vagina' & ә & & & & ә & ә & ә & ә & & $\underline{\breve{\mathrm{u}}}$ & ә \\
\hline *pĭdala- 'defend, rescue' & & & & $\mathrm{i}$ & $\underline{\mathbf{i}}$, ə & & ә & ә & & & \\
\hline *pǔl 'cloud' & ә & ә & & $\mathrm{i}$ & ә & ə & ә & $\breve{1}$ & $\underline{\boldsymbol{\partial}}$ & ә & ә \\
\hline *pül'dəra 'lewd' & ә & & & $\breve{1}$ & ә & ә & & & $\breve{1}$ & & ә \\
\hline *pǔləkš ‘ear’ & ә & ә & ә & $\mathrm{i}$ & ә & ә & ә & ә & $\breve{1}$ & ә & ә \\
\hline *pŭrdəš/ž ‘wall' & ә & & & $\underline{\ddot{\mathbf{u}}}$ & ә & ә & ә & ә & $\underline{\breve{\mathbf{u}}}$ & & \\
\hline *pǔšte- 'put' & ә & $\partial$ & ә & $\mathrm{i}$ & $\partial$ & $\partial$ & $\partial$ & ә & $\breve{1}$ & ә & $\underline{\mathbf{i}}$ \\
\hline *pĭstəl 'feather' & ә & $\partial$ & ә & $\mathrm{i}$ & ә & ә & $\partial, \underline{\mathbf{i}}$ & $\underline{\mathbf{i}}$ & $\underline{\mathbf{i}}$ & $\underline{\mathbf{i}}$ & \\
\hline *pǐzakš 'nest' & $\underline{\mathbf{u}}, \partial$ & ә & ә & $\mathrm{i}$ & ә & ә & $\partial, \underline{\ddot{\mathbf{u}}}$ & $\underline{\breve{\mathrm{u}}}$ & $\underline{\breve{\mathrm{u}}}, \breve{\mathrm{l}}$ & $\underline{\breve{\mathbf{u}}}$ & ә \\
\hline
\end{tabular}




\begin{tabular}{|c|c|c|c|c|c|c|c|c|c|c|c|}
\hline Proto-Mari *̌i: & B & $\mathrm{Kr}$ & $\mathrm{Ka}$ & $\mathbf{K i}$ & $S$ & $\mathbf{M}$ & MU & $\mathbf{U}$ & $\mathbf{V}$ & Nw & $\mathbf{W}$ \\
\hline *rǔwəž 'fox' & ә & ә & ә & $\mathrm{i}$ & ә & ә & $\underline{\ddot{u}}$ & $\underline{\breve{\mathrm{u}}}$ & & ә & ә \\
\hline *sǔla- 'esape, hide' & ә & ә & ә & $\mathrm{i}$ & ә & ә & ә & ә & $\breve{1}$ & ә & ә \\
\hline *śír 'nature, character' & ә & & & & ә & & & ә & & & ә \\
\hline *śĭre- 'get angry' & ә & ә & ә & $\mathrm{i}$ & ә & ә & ә & $\underline{\underline{\mathbf{i}}}$ & $\underline{\partial}$ & & \\
\hline * šĭm * ̌̌̌̌̌̌m 'seven' & ә & ә & ә & $\mathrm{i}$ & $\partial$ & ә & ә & ә & $\breve{1}$ & ә & ә \\
\hline *šĭdə 'hatred' & $\underline{\mathbf{i}}, \partial$ & $\underline{\mathbf{i}}$ & $\underline{\mathbf{i}}$ & $\mathrm{i}$ & ə & ә & ә & ә & $\breve{1}$ & ә & ə \\
\hline *šĭgəl’ə 'wart' & ә & ә & ә & $\mathrm{i}$ & $\partial$ & ә & ә & ә & $\breve{1}$ & ә & $\partial$ \\
\hline *šǐkš 'smoke' & $\underline{\mathbf{i}}$ & $\underline{\mathbf{i}}$ & $\underline{\mathbf{i}}$ & $\mathrm{i}$ & $\underline{\mathbf{i}}$ & $\underline{\mathbf{i}}$, ə & $\underline{\mathbf{i}}$ & $\underline{\mathbf{i}}$ & $\breve{1}$ & ә & ә \\
\hline *šll 'meat' & ә & ә & ә & $\mathrm{i}$ & ә & ə & ә & ә & $\breve{1}$ & ә & ə \\
\hline *Š1llə̌̌ 'lower back' & ә & ә & ә & & ә & ә & ә & ә & & ә & ә \\
\hline *šĭma 'dark (of clouds)' & ә & & & $\mathrm{i}$ & ә & ә & & ә & & ә & ә \\
\hline *šíńća ‘eye’ & $\mathrm{i}$ & $\mathrm{i}$ & $\mathrm{i}$ & $\mathrm{i}$ & $\mathrm{i}$ & $\mathrm{i}$ & $i, \underline{\boldsymbol{\theta}}$ & ә & $\breve{1}$ & $\breve{1}$ & $\breve{1}, \partial$ \\
\hline $\begin{array}{l}\text { * Šíńća- 'sit down', *šĭńće- 'sit, } \\
\text { stand' }\end{array}$ & $\mathrm{i}$ & $\mathrm{i}$ & $\mathrm{i}$ & $\mathrm{i}$ & $\mathrm{i}$ & $\mathrm{i}$ & $\mathrm{i}, \underline{\boldsymbol{\theta}}$ & ә & $\breve{1}$ & $\breve{1}$ & $\breve{1}, \partial$ \\
\hline * Šíńće- 'know' & $\mathrm{i}$ & $\mathrm{i}$ & $\mathrm{i}$ & $\mathrm{i}$ & $\mathrm{i}$ & $\mathrm{i}$ & $\mathrm{i}$ & ә & $\breve{1}$ & $\breve{1}$ & $\breve{1}$ \\
\hline *Šĭnde- 'put, set' & ә & ә & ә & $\mathrm{i}$ & ә & ә & ә & ә & $\breve{1}$ & $\breve{1}$ & $\breve{1}, \partial$ \\
\hline *šĭne- 'check, keep an eye on' & ә & & & & ә & & & & & & ə \\
\hline * šr̆re- 'grimace' & ә & & & i & & ә & ә & ә & & & \\
\hline *šřrkama 'brooch' & ә & ә & & $\mathrm{i}$ & ә & ә & & $\underline{\breve{\mathbf{u}}}$ & $\breve{1}$ & $\underline{\breve{\mathrm{u}}}$ & ə \\
\hline *Šĭrt 'evil spirit (of illness)' & ә & & & & ə & ә & & ә & & ә & \\
\hline *šǐštə 'wax' & $\underline{\mathbf{i}}$ & $\underline{\mathbf{i}}$ & $\underline{\mathbf{i}}$ & $\mathrm{i}$ & $\underline{\mathbf{i}}$ & $\underline{\mathbf{i}}, \partial$ & ә & ә & $\breve{1}$ & ә & ə \\
\hline *šǐža 'drizzle' (+ derivatives) & ә & ә & & $\mathrm{i}$ & ә & ә & ә & $\underline{\breve{\mathrm{u}}}$ & $\breve{1}$ & $\partial$ & ә \\
\hline *Šǐžo ‘autumn' & ə, $\underline{\mathbf{i}}$ & ә & $\underline{\mathbf{i}}$ & $\mathrm{i}$ & $\underline{\mathbf{i}}$ & ә & ә & $\underline{\breve{\mathbf{u}}}$ & $\breve{1}$ & ә, $\underline{\breve{\mathbf{u}}}$ & ә \\
\hline *tǔləća 'moon' & ә & ә & ә & $\mathrm{i}$ & ә & ә & ә & ә & $\breve{1}$ & $\partial$ & ə \\
\hline *tǐń/jo 'you' & ә & $\underline{\mathbf{i}}$ & $\underline{\mathbf{i}}$ & i & $\partial$ & ә & ә & ә & $\breve{1}$ & $\breve{1}, \partial$ & $\breve{1}, \partial$ \\
\hline *tĭnga 'gadfly' & ә & ә & & $\mathrm{i}$ & $\underline{\mathbf{i}}$ & ә & & ә & $\breve{1}$ & $\underline{\mathbf{e}}$ & ә \\
\hline *tĭrtəš 'round' & ә & & & & ә & ә & ә & ә & $\breve{1}$ & ә & ә \\
\hline *wĭć 'five' & $\mathrm{i}$ & $\mathrm{i}$ & $\mathrm{i}$ & $\mathrm{i}$ & $\underline{\mathbf{i}}$ & $\underline{\mathbf{i}}$ & $\underline{\mathbf{i}}, \partial$ & ә & $\underline{\mathbf{i}}$ & ә & ә \\
\hline *wĭćkəž 'thin' & $\mathrm{i}$ & $\mathrm{i}$ & $\mathrm{i}$ & $\mathrm{i}$ & $\underline{\mathbf{i}}$ & ә & ә & ә & $\breve{1}$ & ә & ә \\
\hline *wı̌ńər 'linen' & $\underline{\underline{\partial}}, \mathrm{i}$ & $\mathrm{i}$ & $\mathrm{i}$ & $\mathrm{i}$ & ә & ә & ә & ә & $\breve{1}$ & ә & ə \\
\hline *wĭrlangə 'wagtail, titmouse' & ә & & & & ә & $\underline{\ddot{\mathbf{u}}}$ & & ә & & $\underline{\breve{\mathrm{u}}}$ & ә \\
\hline
\end{tabular}




\begin{tabular}{|c|c|c|c|c|c|c|c|c|c|c|c|}
\hline Proto-Mari * ŭ: & B & $\mathbf{K r}$ & $\mathrm{Ka}$ & $\mathbf{K i}$ & $S$ & $\mathbf{M}$ & MU & $\mathbf{U}$ & $\mathbf{V}$ & $\mathrm{Nw}$ & $\mathbf{W}$ \\
\hline *čŭme- 'tread' & $\mathrm{u}$ & $\mathrm{u}$ & & $\mathrm{u}$ & $\mathrm{u}$ & $\mathrm{u}$ & $\mathrm{u}$ & $\underline{\hat{\theta}}$ & & $\underline{\hat{\theta}}$ & $\hat{\partial}$ \\
\hline *jŭgəńća- 'have hiccups' & $\underline{\ddot{u}}$ & $\underline{\ddot{u}}$ & $\underline{\ddot{\mathbf{u}}}$ & $\underline{\ddot{\mathbf{u}}}$ & $\underline{\ddot{u}}$ & $\underline{\ddot{\mathbf{u}}}$ & $\mathrm{u}$ & $\breve{\mathrm{u}}$ & & $\underline{\hat{\mathbf{o}}}$ & $\underline{\boldsymbol{\theta}}$ \\
\hline *jŭle- 'burn' & $\underline{\ddot{u}}$ & $\underline{\ddot{\mathbf{u}}}$ & $\underline{\ddot{u}}$ & $\underline{\ddot{\mathbf{u}}}$ & $\underline{\ddot{\mathbf{u}}}$ & $\underline{\ddot{\mathbf{u}}}$ & $\mathrm{u}$ & $\breve{\mathrm{u}}$ & $\underline{\hat{\mathrm{o}}}$ & $\underline{\hat{\mathbf{d}}}$ & $\underline{\mathrm{\theta}}$ \\
\hline *jŭmə 'god' & $\mathrm{u}$ & $\mathrm{u}$ & $\mathrm{u}$ & $\mathrm{u}$ & $\mathrm{u}$ & $\mathrm{u}$ & $\mathrm{u}$ & $\breve{\mathrm{u}}$ & $\breve{\mathrm{u}}$ & $\breve{o}$ & $\hat{\partial}$ \\
\hline *jŭt 'night' & $\underline{\ddot{\mathbf{i}}}$ & $\underline{\ddot{\mathbf{u}}}$ & $\underline{\ddot{\mathrm{u}}}$ & $\underline{\mathrm{u}}$ & $\underline{\mathrm{u}}$ & $\underline{\mathrm{u}}$ & $\underline{\ddot{\mathbf{u}}}$ & $\underline{\ddot{\mathbf{u}}}$ & $\breve{\mathrm{u}}$ & $\breve{o}$ & $\hat{\partial}, \underline{\partial}$ \\
\hline $\begin{array}{l}{ }^{*} \text { kŭ- (interrogative pronoun } \\
\text { root) }\end{array}$ & $\mathrm{u}$ & $\mathrm{u}$ & $\mathrm{u}$ & $\mathrm{u}$ & $\mathrm{u}$ & $\mathrm{u}$ & $\mathrm{u}$ & $\breve{\mathrm{u}}$ & $\breve{\mathrm{u}}$ & $\breve{~ o ̆}$ & $\hat{\partial}$ \\
\hline *kŭče- 'hold, grab' & $\mathrm{u}$ & $\mathrm{u}$ & $\mathrm{u}$ & $\mathrm{u}$ & $\mathrm{u}$ & $\mathrm{u}$ & $\mathrm{u}$ & $\breve{\mathrm{u}}$ & $\breve{\mathrm{u}}$ & $\underline{\hat{\theta}}$ & $\hat{\partial}$ \\
\hline $\begin{array}{l}\text { *kŭdala- 'run (animal); ride } \\
\text { fast' }\end{array}$ & $\mathrm{u}$ & $\mathrm{u}$ & $\mathrm{u}$ & & $\mathrm{u}$ & $\mathrm{u}$ & $\mathrm{u}$ & $\breve{\mathrm{u}}$ & $\breve{\mathrm{u}}$ & $\underline{\hat{\mathbf{g}}}$ & $\hat{\partial}$ \\
\hline *kŭdakša- 'take off' & $\mathrm{u}$ & & $\mathrm{u}$ & $\mathrm{u}$ & $\mathrm{u}$ & $\mathrm{u}$ & $\mathrm{u}$ & $\underline{\mathbf{u}}$ & $\breve{\mathrm{u}}$ & $\underline{\hat{\mathrm{o}}}$ & $\hat{\partial}$ \\
\hline *kŭm 'three' & $\mathrm{u}$ & $\mathrm{u}$ & $\mathrm{u}$ & $\mathrm{u}$ & $\mathrm{u}$ & $\mathrm{u}$ & $\mathrm{u}$ & $\breve{\mathrm{u}}$ & $\breve{\mathrm{u}}$ & $\breve{\mathrm{o}}$ & $\hat{\partial}$ \\
\hline *kŭmda 'broad' & $\mathrm{u}$ & $\mathrm{u}$ & $\mathrm{u}$ & $\mathrm{u}$ & $\mathrm{u}$ & $\mathrm{u}$ & & $\breve{\mathrm{u}}$ & & $\breve{o}$ & $\hat{\partial}$ \\
\hline *kŭme- 'close the eyes' & $\mathrm{u}$ & $\mathrm{u}$ & $\mathrm{u}$ & $\mathrm{u}$ & $\mathrm{u}$ & $\mathrm{u}$ & $\mathrm{u}$ & $\breve{\mathrm{u}}$ & & $\breve{o}$ & $\hat{\partial}$ \\
\hline *kŭmək 'upside down' & $\mathrm{u}$ & $\mathrm{u}$ & & & $\mathrm{u}$ & $\mathrm{u}$ & $\mathrm{u}$ & $\breve{\mathrm{u}}$ & $\breve{\mathrm{u}}$ & $\breve{\mathrm{o}}$ & $\hat{\partial}$ \\
\hline *kŭməž 'birch-bark' & $\mathrm{u}$ & $\mathrm{u}$ & $\mathrm{u}$ & $\mathrm{u}$ & $\mathrm{u}$ & $\mathrm{u}$ & $\mathrm{u}$ & $\breve{\mathrm{u}}$ & $\breve{\mathrm{u}}$ & ŏ & $\hat{\partial}$ \\
\hline *kŭnəž 'dirt' & $\mathrm{u}$ & & & & & & & $\breve{\mathrm{u}}$ & & & $\hat{\partial}$ \\
\hline *kŭpe- 'get moldy' & & & & & & & $\mathrm{u}$ & $\breve{\mathrm{u}}$ & $\breve{\mathrm{u}}$ & ŏ & $\hat{\partial}$ \\
\hline *kŭpšəl’ə ‘jay’ & & $\mathrm{u}$ & & $\mathrm{u}$ & $\mathrm{u}$ & $\mathrm{u}$ & $\mathrm{u}$ & $\breve{\mathrm{u}}$ & & ŏ & $\hat{\partial}$ \\
\hline *kŭptərge- 'get wrinkled' & $\mathrm{u}$ & $\mathrm{u}$ & & $\mathrm{u}$ & $\mathrm{u}$ & $\mathrm{u}$ & & $\breve{\mathrm{u}}$ & $\breve{\mathrm{u}}$ & ŏ & $\hat{\partial}$ \\
\hline *kŭrala- 'plough' & $\mathrm{u}$ & $\mathrm{u}$ & $\mathrm{u}$ & $\mathrm{u}$ & $\mathrm{u}$ & $\mathrm{u}$ & $\mathrm{u}$ & $\breve{\mathrm{u}}$ & $\breve{\mathrm{u}}$ & $\underline{\hat{\hat{\theta}}}$ & $\hat{\partial}$ \\
\hline *kŭrək 'mountain' & $\mathrm{u}$ & $\mathrm{u}$ & $\mathrm{u}$ & $\mathrm{u}$ & $\mathrm{u}$ & $\mathrm{u}$ & $\mathrm{u}$ & $\breve{\mathrm{u}}$ & & $\breve{\mathrm{o}}$ & $\hat{\partial}$ \\
\hline *kŭrəkš 'bark basket' & $\mathrm{u}$ & $\mathrm{u}$ & & & & $\mathrm{u}$ & $\mathrm{u}$ & $\breve{\mathrm{u}}$ & $\breve{\mathrm{u}}$ & $\breve{\mathrm{o}}$ & $\hat{\partial}$ \\
\hline *kŭrga 'food, fodder' & & & & & $\mathrm{u}$ & & & $\breve{\mathrm{u}}$ & & $\breve{\mathrm{o}}$ & \\
\hline *kŭrgəža- 'run' & $\mathrm{u}$ & $\mathrm{u}$ & $\mathrm{u}$ & $\mathrm{u}$ & $\mathrm{u}$ & $\mathrm{u}$ & $\mathrm{u}$ & $\breve{\mathrm{u}}$ & $\breve{\mathrm{u}}$ & $\breve{\mathrm{o}}$ & $\hat{\partial}$ \\
\hline *kŭrməćak 'woodcock' & $\mathrm{u}$ & & & $\mathrm{u}$ & & $\mathrm{u}$ & $\mathrm{u}$ & $\breve{\mathrm{u}}$ & $\breve{\mathrm{u}}$ & & $\hat{\partial}$ \\
\hline *kŭškeda- 'tear' & $\mathrm{u}$ & $\mathrm{u}$ & $\mathrm{u}$ & $\mathrm{u}$ & $\mathrm{u}$ & $\mathrm{u}$ & $\mathrm{u}$ & $\breve{\mathrm{u}}$ & $\breve{\mathrm{u}}$ & ŏ & $\hat{\partial}$ \\
\hline *kǔškəža- 'mount (horse)' & $\mathrm{u}$ & $\mathrm{u}$ & $\mathrm{u}$ & $\mathrm{u}$ & $\mathrm{u}$ & $\mathrm{u}$ & $\mathrm{u}$ & $\breve{\mathrm{u}}$ & & & $\hat{\partial}$ \\
\hline *kŭt 'length' & $\mathrm{u}$ & & & $\mathrm{u}$ & $\mathrm{u}$ & $\mathrm{u}$ & & $\breve{\mathrm{u}}$ & $\breve{\mathrm{u}}$ & $\breve{~ o ̆}$ & $\hat{\partial}$ \\
\hline *kŭtkə 'ant' & $\mathrm{u}$ & $\mathrm{u}$ & $\mathrm{u}$ & $\mathrm{u}$ & $\mathrm{u}$ & $\mathrm{u}$ & $\mathrm{u}$ & $\breve{\mathrm{u}}$ & $\breve{\mathrm{u}}$ & $\breve{o}$ & $\hat{\partial}$ \\
\hline *kŭwa 'old woman' & $\mathrm{u}$ & $\mathrm{u}$ & $\mathrm{u}$ & $\mathrm{u}$ & $\mathrm{u}$ & $\mathrm{u}$ & $\mathrm{u}$ & $\breve{\mathrm{u}}$ & $\breve{\mathrm{u}}$ & $\breve{o}$ & $\hat{\partial}$ \\
\hline *kŭwəl 'bubble' & & & & $\mathrm{u}$ & $\mathrm{u}$ & $\mathrm{u}$ & & $\breve{\mathrm{u}}$ & & $\breve{O}$ & $\hat{\partial}$ \\
\hline *kǔž 'urine' & & & & & & & $\mathrm{u}$ & $\breve{\mathrm{u}}$ & $\breve{\mathrm{u}}$ & $\breve{\mathrm{o}}$ & $\hat{\partial}$ \\
\hline *lŭda- 'count' & $\mathrm{u}$ & $\mathrm{u}$ & & $\mathrm{u}$ & $\mathrm{u}$ & $\mathrm{u}$ & $\mathrm{u}$ & $\underline{\mathbf{u}}$ & $\breve{\mathrm{u}}$ & $\underline{\mathbf{u}}$ & $\hat{\partial}$ \\
\hline *lŭdə 'duck' & $\mathrm{u}$ & $\mathrm{u}$ & $\mathrm{u}$ & $\mathrm{u}$ & $\mathrm{u}$ & $\mathrm{u}$ & $\mathrm{u}$ & $\breve{\mathrm{u}}$ & $\underline{\mathbf{u}}$ & $\breve{\mathrm{o}}$ & $\hat{\partial}$ \\
\hline *lŭge- 'mix' & $\mathrm{u}$ & $\mathrm{u}$ & $\mathrm{u}$ & $\mathrm{u}$ & $\mathrm{u}$ & $\mathrm{u}$ & $\mathrm{u}$ & $\breve{\mathrm{u}}$ & $\breve{\mathrm{u}}$ & $\underline{\mathbf{o}}$ & $\hat{\partial}$ \\
\hline *lŭj 'marten' & $\mathrm{u}$ & & $\mathrm{u}$ & $\mathrm{u}$ & $\mathrm{u}$ & $\mathrm{u}$ & $\mathrm{u}$ & $\underline{\mathbf{u}}$ & $\underline{\mathbf{u}}$ & $\underline{\mathbf{u}}$ & ô \\
\hline *lŭk 'corner, bend' & $\mathrm{u}$ & $\mathrm{u}$ & $\mathrm{u}$ & $\mathrm{u}$ & $\mathrm{u}$ & $\mathrm{u}$ & & $\breve{\mathrm{u}}$ & $\breve{\mathrm{u}}$ & $\breve{O}$ & $\hat{\partial}$ \\
\hline *lŭkta- 'take out' & $\mathrm{u}$ & $\mathrm{u}$ & $\mathrm{u}$ & $\mathrm{u}$ & $\mathrm{u}$ & $\mathrm{u}$ & $\mathrm{u}$ & $\breve{\mathrm{u}}$ & $\breve{\mathrm{u}}$ & $\breve{O}$ & $\hat{\partial}$ \\
\hline *lŭm ‘snow' & $\mathrm{u}$ & $\mathrm{u}$ & $\mathrm{u}$ & $\mathrm{u}$ & $\mathrm{u}$ & $\mathrm{u}$ & $\mathrm{u}$ & $\breve{\mathrm{u}}$ & $\breve{\mathrm{u}}$ & $\breve{\mathrm{o}}$ & $\hat{\partial}$ \\
\hline
\end{tabular}




\begin{tabular}{|c|c|c|c|c|c|c|c|c|c|c|c|}
\hline Proto-Mari *ŭ: & B & $\mathbf{K r}$ & $\mathrm{Ka}$ & $\mathbf{K i}$ & $S$ & $\mathbf{M}$ & MU & $\mathbf{U}$ & $\mathbf{V}$ & Nw & $\mathbf{W}$ \\
\hline *lŭmej ‘blackfly’ & $\mathrm{u}, \underline{\ddot{\mathrm{u}}}$ & $\mathrm{u}$ & & $\mathrm{u}$ & & $\mathrm{u}$ & $\mathrm{u}$ & $\breve{\mathrm{u}}$ & & ŏ & $\hat{\partial}$ \\
\hline *lŭpš ‘dew’ & $\mathrm{u}$ & $\mathrm{u}$ & $\mathrm{u}$ & $\mathrm{u}$ & $\mathrm{u}$ & $\mathrm{u}$ & $\mathrm{u}$ & $\breve{\mathrm{u}}$ & $\breve{\mathrm{u}}$ & ŏ & $\hat{\partial}$ \\
\hline *lŭpš ‘whip' & $\mathrm{u}$ & $\mathrm{u}$ & $\mathrm{u}$ & $\mathrm{u}$ & $\mathrm{u}$ & $\mathrm{u}$ & $\mathrm{u}$ & $\breve{\mathrm{u}}$ & $\breve{\mathrm{u}}$ & $\breve{o}$ & $\hat{\partial}$ \\
\hline *lǔške- 'loosen' & $\mathrm{u}$ & $\mathrm{u}$ & & $\mathrm{u}$ & $\mathrm{u}$ & $\mathrm{u}$ & $\mathrm{u}$ & $\underline{\mathbf{u}}$ & $\breve{\mathrm{u}}$ & $\underline{\mathbf{u}}$ & $\hat{\partial}$ \\
\hline *mŭnćalte- *pŭnćalte- 'slide’ & $\mathrm{u}$ & $\mathrm{u}$ & $\mathrm{u}$ & $\mathrm{u}$ & $\mathrm{u}$ & $\mathrm{u}$ & $\mathrm{u}$ & $\breve{\mathrm{u}}$ & & $\breve{~}$ & \\
\hline *mŭč 'end' & $\mathrm{u}$ & $\mathrm{u}$ & $\mathrm{u}$ & $\mathrm{u}$ & $\mathrm{u}$ & $\mathrm{u}$ & $\mathrm{u}$ & $\breve{\mathrm{u}}, \underline{\mathbf{u}}$ & $\breve{\mathrm{u}}$ & ŏ, $\underline{\hat{\mathbf{a}}}$ & $\hat{\partial}$ \\
\hline *mŭćə 'hazel grouse' & $\mathrm{u}$ & & & $\mathrm{u}$ & $\mathrm{u}$ & $\underline{\hat{\theta}}, \underline{\mathbf{i}}$ & $\mathrm{u}$ & $\breve{\mathrm{u}}$ & $\underline{\mathbf{i}}$ & $\breve{\mathrm{o}}$ & $\hat{\partial}$ \\
\hline *mŭčə-wuj 'tussock' & $\mathrm{u}$ & $\mathrm{u}$ & $\mathrm{u}$ & $\mathrm{u}$ & $\mathrm{u}$ & & $\mathrm{u}$ & $\breve{\mathrm{u}}, \underline{\mathbf{u}}$ & & $\breve{\mathrm{o}}$ & $\hat{\partial}$ \\
\hline *mŭgəl’ə 'gnarl' & $\mathrm{u}$ & $\mathrm{u}$ & & $\mathrm{u}$ & $\mathrm{u}$ & $\mathrm{u}, \underline{\hat{\mathrm{o}}}$ & $\mathrm{u}$ & $\breve{\mathrm{u}}$ & $\breve{\mathrm{u}}$ & $\breve{\mathrm{o}}$ & $\hat{\partial}$ \\
\hline *mŭgər 'bend' & & & & & & $\mathrm{u}$ & & $\breve{\mathrm{u}}$ & & & $\hat{\partial}$ \\
\hline *mŭndəra 'ball (of yarn)' & $\mathrm{u}$ & $\mathrm{u}$ & $\mathrm{u}$ & $\mathrm{u}$ & $\mathrm{u}$ & $\mathrm{u}$ & $\mathrm{u}$ & $\breve{\mathrm{u}}$ & & ŏ & ô \\
\hline *mŭnə 'egg' & $\mathrm{u}$ & $\mathrm{u}$ & $\mathrm{u}$ & $\mathrm{u}$ & $\mathrm{u}$ & $\mathrm{u}$ & $\mathrm{u}$ & $\breve{\mathrm{u}}$ & $\breve{\mathrm{u}}$ & $\breve{\text { o }}$ & $\hat{\partial}$ \\
\hline *mŭńəj 'toad' & $\mathrm{u}$ & $\mathrm{u}$ & $\mathrm{u}$ & $\mathrm{u}$ & & & & $\breve{\mathrm{u}}$ & & & $\hat{\partial}$ \\
\hline *mŭra 'song' & $\mathrm{u}$ & $\mathrm{u}$ & $\mathrm{u}$ & $\mathrm{u}$ & $\mathrm{u}$ & $\mathrm{u}$ & $\mathrm{u}$ & $\breve{\mathrm{u}}$ & $\breve{\mathrm{u}}$ & $\breve{\mathrm{o}}$ & $\hat{\partial}$ \\
\hline *mǔška- 'wash' & $\mathrm{u}$ & $\mathrm{u}$ & $\mathrm{u}$ & $\mathrm{u}$ & $\mathrm{u}$ & $\mathrm{u}$ & $\mathrm{u}$ & $\breve{\mathrm{u}}$ & $\breve{\mathrm{u}}$ & $\breve{~ o ̆}$ & $\hat{\partial}$ \\
\hline *mŭškəndə 'fist' & $\mathrm{u}$ & $\mathrm{u}$ & $\mathrm{u}$ & $\mathrm{u}$ & $\mathrm{u}$ & $\mathrm{u}$ & $\mathrm{u}$ & $\breve{\mathrm{u}}$ & $\breve{\mathrm{u}}$ & $\breve{O}$ & $\hat{\partial}$ \\
\hline *mǔžeda- 'tell the fortune' & $\mathrm{u}$ & $\mathrm{u}$ & $\mathrm{u}$ & $\mathrm{u}$ & $\mathrm{u}$ & $\mathrm{u}$ & $\mathrm{u}$ & $\breve{\mathrm{u}}$ & $\breve{\mathrm{u}}$ & $\breve{o}$ & $\underline{\mathbf{u}}$ \\
\hline *mŭžə 'illness; evil spirit' & $\mathrm{u}$ & $\mathrm{u}$ & & $\mathrm{u}$ & $\mathrm{u}$ & & $\mathrm{u}$ & & & & $\hat{\partial}$ \\
\hline *mŭśge- 'chew something soft' & & & & & & $\mathrm{u}$ & & $\breve{\mathrm{u}}$ & & $\underline{\hat{\mathbf{o}}}$ & $\hat{\partial}$ \\
\hline *nŭćəl- 'scratch' & $\mathrm{u}$ & & & $\mathrm{u}$ & $\mathrm{u}$ & $\mathrm{u}$ & & $\breve{\mathrm{u}}$ & & $\underline{\hat{\mathrm{o}}}$ & $\hat{\partial}$ \\
\hline *nŭgədə 'thick (of fluids)' & $\mathrm{u}$ & & $\mathrm{u}$ & $\mathrm{u}$ & $\mathrm{u}$ & $\mathrm{u}$ & $\mathrm{u}$ & $\breve{\mathrm{u}}$ & $\breve{\mathrm{u}}$ & $\breve{~ o ~}$ & $\hat{\partial}$ \\
\hline *nŭle- 'lick' & $\mathrm{u}$ & $\mathrm{u}$ & $\mathrm{u}$ & $\mathrm{u}$ & $\mathrm{u}$ & $\mathrm{u}$ & $\mathrm{u}$ & $\breve{\mathrm{u}}$ & $\breve{\mathrm{u}}$ & $\breve{O}$ & $\hat{\partial}$ \\
\hline *nŭlgə 'silver fir' & $\mathrm{u}$ & $\mathrm{u}$ & & $\mathrm{u}$ & $\mathrm{u}$ & $\mathrm{u}$ & & $\underline{\mathbf{u}}$ & & $\breve{O}$ & \\
\hline *nŭnə 'they' & $\mathrm{u}$ & $\mathrm{u}$ & & & $\mathrm{u}$ & $\mathrm{u}$ & $\mathrm{u}$ & $\underline{\breve{\mathrm{u}}}$ & $\breve{\mathrm{u}}$ & $\underline{\breve{\mathrm{u}}}$ & $\underline{\partial}$ \\
\hline *nŭr 'field' & $\mathrm{u}$ & $\mathrm{u}$ & $\mathrm{u}$ & $\mathrm{u}$ & $\mathrm{u}$ & $\mathrm{u}$ & $\mathrm{u}$ & $\breve{\mathrm{u}}$ & $\breve{\mathrm{u}}$ & $\breve{o}$ & $\hat{\partial}$ \\
\hline *nǔška-, 'nǔškəšta- 'crawl' & $\mathrm{u}$ & $\mathrm{u}$ & & $\mathrm{u}$ & $\mathrm{u}$ & $\mathrm{u}$ & & $\breve{\mathrm{u}}$ & & $\breve{\mathrm{o}}$ & \\
\hline *pǔč 'stalk, tube' & $\mathrm{u}$ & $\mathrm{u}$ & $\mathrm{u}$ & $\mathrm{u}$ & $\mathrm{u}$ & $\mathrm{u}$ & $\mathrm{u}$ & $\breve{\mathrm{u}}$ & $\breve{\mathrm{u}}$ & ŏ, $\underline{\hat{z}}$ & $\hat{\partial}$ \\
\hline *pǔče- 'fall (of water level)' & $\mathrm{u}$ & $\mathrm{u}$ & & $\mathrm{u}$ & $\mathrm{u}$ & $\mathrm{u}$ & $\mathrm{u}$ & $\breve{\mathrm{u}}$ & $\breve{\mathrm{u}}$ & $\breve{\mathrm{o}}$ & $\hat{\partial}$ \\
\hline *pǔčəšte- 'itch' & $\mathrm{u}$ & & & & $\mathrm{u}$ & $\mathrm{u}$ & & $\breve{\mathrm{u}}$ & $\breve{\mathrm{u}}$ & $\breve{\mathrm{O}}$ & $\hat{\partial}$ \\
\hline *pŭdešta- 'burst' & $\mathrm{u}$ & $\mathrm{u}$ & & $\mathrm{u}$ & $\mathrm{u}$ & $\mathrm{u}$ & $\mathrm{u}$ & $\breve{\mathrm{u}}$ & $\breve{\mathrm{u}}$ & $\breve{~ o ̆}$ & $\hat{\partial}$ \\
\hline *pŭdərge- 'break' & $\mathrm{u}$ & $\mathrm{u}$ & $\mathrm{u}$ & $\mathrm{u}$ & $\mathrm{u}$ & $\mathrm{u}$ & $\mathrm{u}$ & $\breve{\mathrm{u}}$ & $\breve{\mathrm{u}}$ & $\breve{\mathrm{o}}$ & $\hat{\partial}$ \\
\hline *pŭl-wuj 'knee' & $\mathrm{u}$ & $\mathrm{u}$ & $\mathrm{u}$ & $\mathrm{u}$ & $\mathrm{u}$ & $\mathrm{u}$ & $\mathrm{u}$ & $\breve{\mathrm{u}}$ & $\underline{\mathbf{u}}$ & $\underline{\mathbf{u}}$ & $\hat{\partial}, \underline{\mathbf{u}}$ \\
\hline *pŭn 'hair' & $\mathrm{u}$ & $\mathrm{u}$ & $\mathrm{u}$ & $\mathrm{u}$ & $\mathrm{u}$ & $\mathrm{u}$ & $\mathrm{u}$ & $\breve{\mathrm{u}}$ & $\breve{\mathrm{u}}$ & $\breve{O}$ & $\hat{\partial}$ \\
\hline *pŭńćala- 'wring' & $\mathrm{u}$ & & & & $\mathrm{u}$ & $\mathrm{u}$ & $\mathrm{u}$ & $\breve{\mathrm{u}}$ & $\breve{\mathrm{u}}$ & $\breve{~ o ̆}$ & $\hat{\partial}$ \\
\hline *pŭndaš 'bottom' & $\mathrm{u}$ & $\mathrm{u}$ & $\mathrm{u}$ & $\mathrm{u}$ & $\mathrm{u}$ & $\mathrm{u}$ & $\mathrm{u}$ & $\breve{\mathrm{u}}$ & $\breve{\mathrm{u}}$ & $\breve{\mathrm{o}}$ & $\hat{\partial}$ \\
\hline *pŭne- 'braid' & $\mathrm{u}$ & $\mathrm{u}$ & $\mathrm{u}$ & $\mathrm{u}$ & $\mathrm{u}$ & $\mathrm{u}$ & $\mathrm{u}$ & $\breve{\mathrm{u}}$ & $\breve{\mathrm{u}}$ & $\breve{\mathrm{o}}$ & $\hat{\partial}$ \\
\hline *pŭńəlmə ‘bumblebee' & & & & & & & $\mathrm{u}$ & $\breve{\mathrm{u}}$ & & ŏ & $\hat{\partial}$ \\
\hline *pŭnəške- 'get moldy' & $\underline{\ddot{\mathbf{u}}}$ & & $\underline{\mathrm{u}}$ & & $\underline{\mathrm{u}}$ & $\underline{\hat{\mathbf{o}}}$ & & $\breve{\mathrm{u}}$ & $\breve{\mathrm{u}}$ & $\breve{\mathrm{o}}$ & $\hat{\partial}$ \\
\hline *pŭra- 'bite, chew' & $\mathrm{u}$ & $\mathrm{u}$ & $\mathrm{u}$ & $\mathrm{u}$ & $\mathrm{u}$ & $\mathrm{u}$ & $\mathrm{u}$ & $\breve{\mathrm{u}}$ & $\breve{\mathrm{u}}$ & $\breve{O}$ & $\hat{\partial}$ \\
\hline *pŭre- 'enter' & $\mathrm{u}$ & $\mathrm{u}$ & $\mathrm{u}$ & $\mathrm{u}$ & $\mathrm{u}$ & $\mathrm{u}$ & $\mathrm{u}$ & $\breve{\mathrm{u}}$ & $\breve{\mathrm{u}}$ & $\breve{o}$ & $\hat{\partial}$ \\
\hline
\end{tabular}




\begin{tabular}{|c|c|c|c|c|c|c|c|c|c|c|c|}
\hline Proto-Mari * ŭ: & B & Kr & Ka & $\mathbf{K i}$ & $S$ & $\mathbf{M}$ & MU & $\mathbf{U}$ & $\mathbf{V}$ & Nw & $\mathbf{W}$ \\
\hline *pŭrgeda- 'hoe, dig up, burrow' & $\mathrm{u}$ & & & & $\mathrm{u}$ & $\mathrm{u}$ & $\mathrm{u}$ & $\breve{\mathrm{u}}$ & $\breve{\mathrm{u}}$ & $\breve{\mathrm{o}}$ & $\hat{\partial}$ \\
\hline *pŭrgəšte- 'snow over' & $\mathrm{u}$ & & & $\mathrm{u}$ & $\mathrm{u}$ & $\mathrm{u}$ & $\mathrm{u}$ & $\breve{\mathrm{u}}$ & & $\breve{\mathrm{o}}$ & $\hat{\partial}, \underline{\mathbf{u}}, \underline{\ddot{\mathbf{u}}}$ \\
\hline *pŭskəla- 'sting' & $\underline{\ddot{u}}$ & $\underline{\ddot{\mathbf{u}}}$ & $\underline{\ddot{\mathbf{u}}}$ & $\underline{\ddot{\mathbf{u}}}$ & $\underline{\ddot{\mathbf{u}}}$ & $\mathrm{u}, \underline{\ddot{\mathrm{u}}}$ & $\mathrm{u}$ & $\breve{\mathrm{u}}$ & $\breve{\mathrm{u}}$ & $\breve{O}$ & $\hat{\partial}$ \\
\hline *pŭ̌̌ 'boat' & $\mathrm{u}$ & $\mathrm{u}$ & $\mathrm{u}$ & $\mathrm{u}$ & $\mathrm{u}$ & $\mathrm{u}$ & $\mathrm{u}$ & $\breve{\mathrm{u}}$ & $\breve{\mathrm{u}}$ & $\breve{\mathrm{o}}$ & $\hat{\partial}$ \\
\hline *pǔškeda- 'have diarrhea' & $\mathrm{u}$ & & $\mathrm{u}$ & $\mathrm{u}$ & $\mathrm{u}$ & $\mathrm{u}$ & $\mathrm{u}$ & $\breve{\mathrm{u}}$ & $\breve{\mathrm{u}}$ & ŏ & $\hat{\partial}$ \\
\hline *pǔškədə 'soft' & $\mathrm{u}$ & $\mathrm{u}$ & $\mathrm{u}$ & $\mathrm{u}$ & $\mathrm{u}$ & $\mathrm{u}$ & $\mathrm{u}$ & $\breve{\mathrm{u}}$ & $\breve{\mathrm{u}}$ & ŏ & $\hat{\partial}$ \\
\hline *pŭt, *pŭtərak 'strong' & $\mathrm{u}$ & & & $\mathrm{u}$ & $\mathrm{u}$ & $\mathrm{u}$ & & $\breve{\mathrm{u}}$ & $\underline{\underline{\mathbf{l}}}$ & $\underline{\hat{\mathbf{\theta}}}$ & $\hat{\partial}$ \\
\hline *pǔžar 'plane' & $\mathrm{u}$ & $\mathrm{u}$ & & $\mathrm{u}$ & $\mathrm{u}$ & $\mathrm{u}$ & $\mathrm{u}$ & $\breve{\mathrm{u}}$ & $\breve{\mathrm{u}}$ & $\breve{o}$ & $\hat{\partial}$ \\
\hline *rŭde- 'unbind' & $\mathrm{u}$ & $\mathrm{u}$ & $\mathrm{u}$ & $\mathrm{u}$ & $\mathrm{u}$ & $\mathrm{u}$ & $\mathrm{u}$ & $\breve{\mathrm{u}}$ & $\underline{\mathbf{u}}$ & $\breve{o}$ & ô \\
\hline *rŭmbək 'mud' & $\mathrm{u}$ & $\mathrm{u}$ & & $\mathrm{u}$ & $\mathrm{u}$ & $\mathrm{u}$ & $\mathrm{u}$ & $\breve{\mathrm{u}}$ & & $\breve{o}$ & ô \\
\hline *śŭwan ‘boil, abscess’ & $\underline{\ddot{\mathbf{u}}}$ & $\underline{\ddot{\mathbf{u}}}$ & $\underline{\ddot{\mathbf{u}}}$ & $\underline{\ddot{\mathbf{u}}}$ & & $\underline{\ddot{\mathbf{u}}}$ & & & $\breve{\mathrm{u}}$ & $\underline{\hat{\theta}}$ & $\underline{\mathrm{\theta}}$ \\
\hline *šŭgəńə 'lever' & $\mathrm{u}$ & & $\mathrm{u}$ & $\mathrm{u}$ & $\mathrm{u}$ & $\mathrm{u}$ & & $\breve{\mathrm{u}}$ & $\breve{\mathrm{u}}$ & $\breve{\mathrm{o}}$ & $\hat{\partial}$ \\
\hline *šŭldər 'feather' & $\mathrm{u}$ & $\mathrm{u}$ & $\mathrm{u}$ & $\mathrm{u}$ & $\mathrm{u}$ & $\mathrm{u}$ & $\mathrm{u}$ & $\underline{\mathbf{u}}$ & $\breve{\mathrm{u}}$ & $\breve{\mathrm{o}}$ & $\hat{\partial}$ \\
\hline *šŭle- 'melt' & $\mathrm{u}$ & $\mathrm{u}$ & $\mathrm{u}$ & $\mathrm{u}$ & $\mathrm{u}$ & $\mathrm{u}$ & & $\breve{\mathrm{u}}$ & $\breve{\mathrm{u}}$ & $\breve{\mathrm{o}}$ & â \\
\hline *šŭləkšs 'boot leg' & $\mathrm{u}$ & $\mathrm{u}$ & $\mathrm{u}$ & $\mathrm{u}$ & $\mathrm{u}$ & $\mathrm{u}$ & $\mathrm{u}$ & $\breve{\mathrm{u}}$ & $\breve{\mathrm{u}}$ & $\breve{o}$ & \\
\hline *šŭma- 'get tired' & $\mathrm{u}$ & $\mathrm{u}$ & & $\mathrm{u}$ & $\mathrm{u}$ & $\mathrm{u}$ & & $\breve{\mathrm{u}}$ & & $\breve{o}$ & $\hat{\partial}$ \\
\hline *šŭme- 'whet' & $\mathrm{u}$ & $\mathrm{u}$ & $\mathrm{u}$ & $\mathrm{u}$ & $\mathrm{u}$ & $\mathrm{u}$ & $\mathrm{u}$ & $\breve{\mathrm{u}}$ & $\breve{\mathrm{u}}$ & $\breve{O}$ & $\hat{\partial}$ \\
\hline *šŭngalta- 'fall head-on' & $\mathrm{u}$ & $\mathrm{u}$ & $\mathrm{u}$ & $\mathrm{u}$ & $\mathrm{u}$ & $\mathrm{u}$ & & $\breve{\mathrm{u}}$ & $\breve{\mathrm{u}}$ & & $\hat{\partial}$ \\
\hline *šŭpša- 'pull, suck' & $\mathrm{u}$ & $\mathrm{u}$ & $\mathrm{u}$ & $\mathrm{u}$ & $\mathrm{u}$ & $\mathrm{u}$ & $\mathrm{u}$ & $\breve{\mathrm{u}}$ & $\breve{\mathrm{u}}$ & $\breve{~}$ & $\hat{\partial}$ \\
\hline *šŭr 'shit' & $\mathrm{u}$ & $\mathrm{u}$ & $\mathrm{u}$ & $\mathrm{u}$ & $\mathrm{u}$ & $\mathrm{u}$ & $\mathrm{u}$ & $\breve{\mathrm{u}}$ & $\breve{\mathrm{u}}$ & ŏ & $\hat{\partial}$ \\
\hline *šŭre- 'pound, crush' & $\mathrm{u}$ & $\mathrm{u}$ & $\mathrm{u}$ & $\mathrm{u}$ & $\mathrm{u}$ & $\mathrm{u}$ & $\mathrm{u}$ & $\breve{\mathrm{u}}$ & $\breve{\mathrm{u}}$ & $\breve{~ o ̆}$ & $\hat{\partial}$ \\
\hline *šŭwəkš 'leather sack' & $\mathrm{u}$ & $\mathrm{u}$ & & $\mathrm{u}$ & $\mathrm{u}$ & $\mathrm{u}$ & $\mathrm{u}$ & $\breve{\mathrm{u}}$ & $\breve{\mathrm{u}}, \underline{\breve{\mathbf{i}}}$ & $\breve{\mathrm{o}}$ & $\underline{\mathbf{u}}$ \\
\hline *tŭdə 'this' & $\mathrm{u}$ & $\mathrm{u}$ & $\mathrm{u}$ & $\mathrm{u}$ & $\mathrm{u}$ & $\mathrm{u}$ & $\mathrm{u}$ & $\underline{\breve{\mathrm{u}}}$ & $\breve{\mathrm{u}}$ & $\underline{\breve{\mathrm{u}}}$ & $\underline{\mathrm{o}}$ \\
\hline *tŭgər 'shirt' & $\mathrm{u}$ & $\mathrm{u}$ & $\mathrm{u}$ & $\mathrm{u}$ & $\mathrm{u}$ & $\mathrm{u}$ & $\mathrm{u}$ & $\breve{\mathrm{u}}$ & $\breve{\mathrm{u}}$ & $\breve{\mathrm{o}}$ & $\hat{\partial}$ \\
\hline *tŭjə 'sick, lean' & $\mathrm{u}$ & & & & $\mathrm{u}$ & $\mathrm{u}$ & & $\underline{\mathbf{u}}$ & $\underline{\mathbf{u}}$ & $\breve{~ o ̆}$ & \\
\hline *tŭl 'fire' & $\mathrm{u}$ & $\mathrm{u}$ & $\mathrm{u}$ & $\mathrm{u}$ & $\mathrm{u}$ & $\mathrm{u}$ & $\mathrm{u}$ & $\breve{\mathrm{u}}$ & $\breve{\mathrm{u}}$ & ŏ & $\hat{\partial}$ \\
\hline *tŭnəma- 'learn' & $\mathrm{u}$ & $\mathrm{u}$ & $\mathrm{u}$ & $\mathrm{u}$ & $\mathrm{u}$ & $\mathrm{u}$ & $\underline{\ddot{\mathbf{u}}}$ & $\underline{\breve{\mathrm{u}}}$ & $\underline{\breve{\mathbf{u}}}$ & ŏ & $\hat{\partial}$ \\
\hline *tŭngər 'thick tree bark' & $\mathrm{u}$ & $\mathrm{u}$ & $\mathrm{u}$ & $\mathrm{u}$ & $\mathrm{u}$ & $\mathrm{u}$ & $\mathrm{u}$ & $\breve{\mathrm{u}}$ & $\breve{\mathrm{u}}$ & $\breve{\mathrm{o}}$ & $\hat{\partial}$ \\
\hline *tŭp 'back' & $\mathrm{u}$ & $\mathrm{u}$ & $\mathrm{u}$ & $\mathrm{u}$ & $\mathrm{u}$ & $\mathrm{u}$ & $\mathrm{u}$ & $\breve{\mathrm{u}}$ & $\breve{\mathrm{u}}$ & $\underline{\mathbf{u}}$ & $\hat{\partial}$ \\
\hline *tŭpka 'heckled flax or hemp' & & & & & & $\mathrm{u}$ & $\mathrm{u}$ & $\breve{\mathrm{u}}$ & $\breve{\mathrm{u}}$ & $\breve{~ o ̆}$ & $\hat{\partial}$ \\
\hline *tŭrta- 'shrink' & $\mathrm{u}$ & $\mathrm{u}$ & $\mathrm{u}$ & $\mathrm{u}$ & $\mathrm{u}$ & $\mathrm{u}$ & $\mathrm{u}$ & $\underline{\mathbf{u}}$ & $\underline{\mathbf{u}}$ & $\breve{\mathrm{O}}$ & $\hat{\partial}$ \\
\hline *tŭrəža- 'trample' & $\mathrm{u}$ & $\mathrm{u}$ & $\mathrm{u}$ & $\mathrm{u}$ & $\mathrm{u}$ & $\mathrm{u}$ & $\mathrm{u}$ & $\breve{\mathrm{u}}$ & $\breve{\mathrm{u}}$ & $\breve{\mathrm{o}}$ & $\hat{\partial}$ \\
\hline *tǔške- 'glue' & $\mathrm{u}$ & & & $\mathrm{u}$ & $\mathrm{u}$ & $\mathrm{u}$ & & $\breve{\mathrm{u}}$ & $\breve{\mathrm{u}}$ & $\breve{\mathrm{o}}$ & $\hat{\partial}$ \\
\hline *tŭšte- 'ask a riddle' & $\mathrm{u}$ & $\mathrm{u}$ & $\mathrm{u}$ & $\mathrm{u}$ & $\mathrm{u}$ & $\mathrm{u}$ & $\mathrm{u}$ & $\underline{\mathbf{u}}$ & $\underline{\mathbf{u}}$ & $\breve{~ o ̆}$ & $\hat{\partial}$ \\
\hline *tŭtəš ‘often, constantly' & $\mathrm{u}$ & & & & $\mathrm{u}$ & $\mathrm{u}$ & & & & & $\hat{\partial}$ \\
\hline *tŭwole- ‘defend, rescue’ & & & & & & & $\mathrm{u}$ & $\breve{\mathrm{u}}$ & & & $\hat{\partial}$ \\
\hline *tŭwərge- 'curdle, turn sour' & $\mathrm{u}$ & $\mathrm{u}$ & $\mathrm{u}$ & $\mathrm{u}$ & $\mathrm{u}$ & $\mathrm{u}$ & & $\breve{\mathrm{u}}$ & $\breve{\mathrm{u}}$ & ŏ & $\hat{\partial}$ \\
\hline *ŭdəla- 'pray for' & $\mathrm{u}$ & $\mathrm{u}$ & & $\mathrm{u}$ & $\mathrm{u}$ & $\mathrm{u}$ & & $\breve{\mathrm{u}}$ & & & $\hat{\partial}$ \\
\hline *ŭdəre- 'rake' & $\mathrm{u}$ & $\mathrm{u}$ & $\mathrm{u}$ & $\mathrm{u}$ & $\mathrm{u}$ & $\mathrm{u}$ & $\mathrm{u}$ & $\breve{\mathrm{u}}$ & $\breve{\mathrm{u}}$ & $\underline{\hat{\mathbf{z}}}$ & $\hat{\partial}$ \\
\hline *ŭla- 'be' & $\mathrm{u}$ & $\mathrm{u}$ & $\mathrm{u}$ & $\mathrm{u}$ & $\mathrm{u}$ & $\mathrm{u}$ & $\mathrm{u}$ & $\breve{\mathrm{u}}$ & $\breve{\mathrm{u}}$ & $\breve{o}$ & $\hat{\partial}$ \\
\hline
\end{tabular}




\begin{tabular}{|c|c|c|c|c|c|c|c|c|c|c|c|}
\hline Proto-Mari ${ }^{*} \breve{\text { ú: }}$ & B & $\mathbf{K r}$ & $\mathbf{K a}$ & $\mathbf{K i}$ & $S$ & $\mathbf{M}$ & MU & $\mathbf{U}$ & $\mathbf{V}$ & Nw & $\mathbf{W}$ \\
\hline *ŭlde- 'ask for' & & & & & & $\mathrm{u}$ & & $\breve{\mathrm{u}}$ & & ŏ & \\
\hline *ŭl'mə 'man' & $\mathrm{u}$ & $\mathrm{u}$ & & & & & & $\underline{\mathbf{u}}$ & & $\breve{o}$ & \\
\hline *ŭmša 'mouth' & $\mathrm{u}$ & $\mathrm{u}$ & $\mathrm{u}$ & $\mathrm{u}$ & $\mathrm{u}$ & $\mathrm{u}$ & $\mathrm{u}$ & $\breve{\mathrm{u}}$ & & $\breve{o}$ & $\underline{\partial}$ \\
\hline *ŭmər 'warm' & $\mathrm{u}$ & $\mathrm{u}$ & & $\mathrm{u}$ & $\mathrm{u}$ & $\mathrm{u}$ & & $\breve{\mathrm{u}}$ & & $\breve{o}$ & \\
\hline *ŭmbal 'distant' & $\mathrm{u}$ & $\mathrm{u}$ & & $\mathrm{u}$ & & $\mathrm{u}$ & $\mathrm{u}$ & $\breve{\mathrm{u}}$ & & ŏ, $\underline{\hat{z}}$ & $\hat{\partial}$ \\
\hline *ŭre- 'put in the ground' & $\mathrm{u}$ & & $\mathrm{u}$ & $\mathrm{u}$ & $\mathrm{u}$ & $\mathrm{u}$ & $\mathrm{u}$ & $\breve{\mathrm{u}}$ & & $\breve{~ o ̆}$ & $\hat{\partial}$ \\
\hline *ŭro 'two handfuls' & $\mathrm{u}$ & & $\mathrm{u}$ & $\mathrm{u}$ & & & & $\breve{\mathrm{u}}$ & & $\breve{o}$ & $\hat{\partial}$ \\
\hline *ŭrge- 'sew' & $\mathrm{u}$ & $\mathrm{u}$ & $\mathrm{u}$ & $\mathrm{u}$ & $\mathrm{u}$ & $\mathrm{u}$ & $\mathrm{u}$ & $\breve{\mathrm{u}}$ & & $\breve{o}$ & $\hat{\partial}$ \\
\hline *ǔžar 'green' & $\mathrm{u}$ & $\mathrm{u}$ & $\mathrm{u}$ & $\mathrm{u}$ & $\mathrm{u}$ & $\mathrm{u}$ & $\mathrm{u}$ & $\breve{\mathrm{u}}$ & $\breve{\mathrm{u}}$ & $\breve{o}$ & $\hat{\partial}, \underline{\emptyset}$ \\
\hline *ǔžga 'fur-coat' & & & & & $\mathrm{u}$ & $\mathrm{u}$ & $\mathrm{u}$ & $\breve{\mathrm{u}}$ & $\breve{\mathrm{u}}$ & $\breve{o}$ & ô \\
\hline *wŭćək 'much' & $\mathrm{u}, \underline{\mathrm{u}}$ & & & $\mathrm{u}$ & $\mathrm{u}$ & $\mathrm{u}$ & & $\breve{\mathrm{u}}$ & & & ô \\
\hline *wŭče- 'wait' & $\mathrm{u}$ & $\mathrm{u}$ & $\mathrm{u}$ & $\mathrm{u}$ & $\mathrm{u}$ & $\mathrm{u}$ & $\mathrm{u}$ & $\breve{\mathrm{u}}$ & $\breve{\mathrm{u}}$ & $\breve{o}$ & ô \\
\hline *wŭl'e- 'get spoiled' & $\mathrm{u}$ & & & & & $\mathrm{u}$ & & $\breve{\mathrm{u}}$ & & & $\hat{\partial}$ \\
\hline *wŭlnə 'tin' & $\mathrm{u}$ & $\mathrm{u}$ & $\mathrm{u}$ & $\mathrm{u}$ & $\mathrm{u}$ & $\mathrm{u}$ & $\mathrm{u}$ & $\breve{\mathrm{u}}$ & $\underline{\mathbf{0}}, \underline{\mathbf{1}}$ & $\breve{\mathrm{o}}$ & $\underline{\mathbf{u}}$ \\
\hline *wŭrde- 'tend' & & $\mathrm{u}$ & & & & & & $\breve{\mathrm{u}}$ & & $\breve{\mathrm{o}}$ & $\underline{\mathbf{u}}$ \\
\hline *wŭrgem 'clothes' & $\mathrm{u}$ & $\mathrm{u}$ & $\mathrm{u}$ & $\mathrm{u}$ & $\mathrm{u}$ & $\mathrm{u}$ & $\mathrm{u}$ & $\breve{\mathrm{u}}$ & $\breve{\mathrm{u}}$ & $\breve{o}$ & $\hat{\partial}$ \\
\hline *wŭrgəže- 'be restless' & $\mathrm{u}$ & & & $\mathrm{u}$ & $\mathrm{u}$ & $\mathrm{u}$ & $\mathrm{u}$ & $\breve{\mathrm{u}}$ & & $\breve{o}$ & $\hat{\partial}$ \\
\hline *wŭrt 'heddle' & $\mathrm{u}$ & $\mathrm{u}$ & $\mathrm{u}$ & $\mathrm{u}$ & $\mathrm{u}$ & $\mathrm{u}$ & $\mathrm{u}$ & $\breve{\mathrm{u}}$ & $\breve{\mathrm{u}}$ & $\breve{o}$ & $\underline{\mathbf{u}}$ \\
\hline *wŭž (onomatopoetic root) & & & & & $\mathrm{u}$ & $\mathrm{u}$ & & $\breve{\mathrm{u}}$ & & $\breve{o}$ & $\hat{\partial}$ \\
\hline *wŭžale- 'buy' & $\mathrm{u}$ & $\mathrm{u}$ & $\mathrm{u}$ & $\mathrm{u}$ & $\mathrm{u}$ & $\mathrm{u}$ & $\mathrm{u}$ & $\breve{\mathrm{u}}$ & $\breve{\mathrm{u}}$ & Ŏ & $\hat{\partial}$ \\
\hline
\end{tabular}




\begin{tabular}{|c|c|c|c|c|c|c|c|c|c|c|c|}
\hline Proto-Mari * ü: & B & $\mathrm{Kr}$ & $\mathrm{Ka}$ & $\mathrm{Ki}$ & $S$ & M & $\mathrm{MU}$ & $\mathrm{U}$ & $\mathrm{V}$ & $\mathrm{Nw}$ & $\mathrm{W}$ \\
\hline *čŭčč 'maternal uncle' & $\ddot{\mathrm{u}}$ & & $\ddot{\mathrm{u}}$ & $\ddot{\mathrm{u}}$ & $\ddot{\mathrm{u}}$ & $\ddot{\mathrm{u}}$ & $\ddot{\mathrm{u}}$ & $\breve{\mathrm{u}}$ & $\breve{\mathrm{u}}$ & $\underline{\mathbf{z}}$ & ә \\
\hline *čŭdə 'lack, need' & $\ddot{\mathrm{u}}$ & & & $\ddot{\mathrm{u}}$ & $\ddot{\mathrm{u}}$ & & & $\underline{\ddot{u}}$ & & & ә \\
\hline *čŭnge- 'peck (of birds)' & $\ddot{\mathrm{u}}$ & $\ddot{\mathrm{u}}$ & $\ddot{\mathrm{u}}$ & $\ddot{\mathrm{u}}$ & $\ddot{\mathrm{u}}$ & $\ddot{\mathrm{u}}$ & & $\breve{\mathrm{u}}$ & $\underline{\underline{1}}$ & $\breve{\mathrm{u}}$ & ә \\
\hline *kǚ̌č 'nail’ & $\ddot{\mathrm{u}}$ & $\ddot{\mathrm{u}}$ & $\ddot{\mathrm{u}}$ & $\ddot{\mathrm{u}}$ & $\ddot{\mathrm{u}}$ & $\ddot{\mathrm{u}}$ & $\ddot{\mathrm{u}}$ & $\underline{\ddot{u}}$ & $\breve{\mathrm{u}}$ & $\breve{\mathrm{u}}$ & ә \\
\hline "küče- 'beg' & $\ddot{\mathrm{u}}$ & $\ddot{\mathrm{u}}$ & $\ddot{\mathrm{u}}$ & $\ddot{\mathrm{u}}$ & $\ddot{\mathrm{u}}$ & $\ddot{\mathrm{u}}$ & $\ddot{\mathrm{u}}$ & $\underline{\ddot{u}}$ & & $\breve{\mathrm{u}}$ & ә \\
\hline "küćə 'knife' & $\ddot{\mathrm{u}}$ & $\ddot{\mathrm{u}}$ & $\ddot{\mathrm{u}}$ & $\ddot{\mathrm{u}}$ & $\ddot{\mathrm{u}}$ & $\ddot{\mathrm{u}}$ & $\ddot{\mathrm{u}}$ & $\underline{\ddot{u}}$ & $\underline{\ddot{u}}$ & $\breve{\mathrm{u}}, \underline{\ddot{u}}$ & ә \\
\hline *küdər 'black grouse' & $\ddot{\mathrm{u}}$ & $\ddot{\mathrm{u}}$ & $\ddot{\mathrm{u}}$ & $\ddot{\mathrm{u}}$ & $\ddot{\mathrm{u}}$ & $\ddot{\mathrm{u}}$ & & $\underline{\underline{\ddot{u}}}$ & $\breve{\mathrm{u}}$ & $\breve{\mathrm{u}}$ & ә \\
\hline *küdərte- 'thunder' & $\ddot{\mathrm{u}}$ & $\ddot{\mathrm{u}}$ & $\ddot{\mathrm{u}}$ & $\ddot{\mathrm{u}}$ & $\ddot{\mathrm{u}}$ & $\ddot{\mathrm{u}}$ & $\ddot{\mathrm{u}}$ & $\underline{\ddot{u}}$ & $\breve{\mathrm{u}}$ & $\breve{\mathrm{u}}$ & ә \\
\hline `kŭnčä- ‘dig' & $\ddot{u}$ & $\ddot{u}$ & $\ddot{\mathrm{u}}$ & $\ddot{\mathrm{u}}$ & $\ddot{u}$ & $\ddot{\mathrm{u}}$ & $\ddot{\mathrm{u}}$ & $\underline{\ddot{u}}$ & & $\breve{\mathrm{u}}$ & \\
\hline *küpš 'nap, fuzz' & $\ddot{u}$ & & & & $\ddot{u}$ & $\ddot{\mathrm{u}}$ & & $\underline{\ddot{u}}$ & $\breve{\mathrm{u}}$ & $\breve{\mathrm{u}}$ & $\underline{\hat{\hat{\theta}}}$ \\
\hline *kür 'bast' & $\ddot{\mathrm{u}}$ & $\ddot{\mathrm{u}}$ & $\ddot{\mathrm{u}}$ & $\ddot{\mathrm{u}}$ & $\ddot{\mathrm{u}}$ & $\ddot{\mathrm{u}}$ & $\ddot{\mathrm{u}}$ & $\underline{\ddot{u}}$ & $\breve{\mathrm{u}}$ & $\breve{\mathrm{u}}$ & ә \\
\hline *küra- 'tear, rip' & $\ddot{\mathrm{u}}$ & $\ddot{\mathrm{u}}$ & $\ddot{\mathrm{u}}$ & $\ddot{\mathrm{u}}$ & $\ddot{\mathrm{u}}$ & $\ddot{\mathrm{u}}$ & $\ddot{\mathrm{u}}$ & $\breve{\mathrm{u}}$ & $\breve{\mathrm{u}}$ & $\breve{\mathrm{u}}$ & ә \\
\hline •kürtńə ‘iron' & $\ddot{\mathrm{u}}$ & $\ddot{\mathrm{u}}$ & $\ddot{\mathrm{u}}$ & $\ddot{\mathrm{u}}$ & $\ddot{\mathrm{u}}$ & $\ddot{\mathrm{u}}$ & $\ddot{\mathrm{u}}$ & $\underline{\underline{\ddot{u}}}$ & $\breve{\mathrm{u}}$ & $\breve{\mathrm{u}}$ & ә \\
\hline *küśedək 'lapwing' & $\ddot{\mathrm{u}}$ & $\ddot{\mathrm{u}}$ & $\underline{\underline{\hat{\theta}}}$ & $\underline{\emptyset}$ & $\ddot{\mathrm{u}}$ & $\ddot{\mathrm{u}}$ & & $\breve{\mathrm{u}}$ & & $\underline{\underline{\partial}}$ & ә \\
\hline *küžgə 'thick' & $\ddot{\mathrm{u}}$ & $\ddot{\mathrm{u}}$ & $\ddot{\mathrm{u}}$ & $\ddot{\mathrm{u}}$ & $\ddot{\mathrm{u}}$ & $\ddot{\mathrm{u}}$ & $\ddot{\mathrm{u}}$ & & $\underline{\ddot{u}}$ & $\breve{\mathrm{u}}$ & ә \\
\hline *lügəšte- 'itch' & $\ddot{\mathrm{u}}$ & $\ddot{\mathrm{u}}$ & $\ddot{\mathrm{u}}$ & $\ddot{\mathrm{u}}$ & $\ddot{\mathrm{u}}$ & $\ddot{\mathrm{u}}$ & $\ddot{\mathrm{u}}$ & $\breve{\mathrm{u}}$ & $\underline{\ddot{u}}$ & $\breve{\mathrm{u}}$ & ә \\
\hline *lükə 'boggy area' & & & & & & $\ddot{\mathrm{u}}$ & & $\underline{\ddot{u}}$ & & $\breve{\mathrm{u}}$ & \\
\hline *lüm 'name' & $\ddot{\mathrm{u}}$ & $\ddot{\mathrm{u}}$ & $\ddot{\mathrm{u}}$ & $\ddot{\mathrm{u}}$ & $\ddot{\mathrm{u}}$ & $\ddot{\mathrm{u}}$ & $\ddot{\mathrm{u}}$ & $\breve{\mathrm{u}}$ & $\breve{\mathrm{u}}$ & $\breve{\mathrm{u}}$ & ә \\
\hline *lümə 'scab' & $\ddot{\mathrm{u}}$ & & & $\ddot{\mathrm{u}}$ & $\ddot{\mathrm{u}}$ & $\ddot{\mathrm{u}}$ & $\ddot{\mathrm{u}}$ & $\breve{\mathrm{u}}$ & $\breve{\mathrm{u}}$ & $\breve{\mathrm{u}}$ & $\underline{\mathbf{i}}$ \\
\hline *lünge- 'rock' & $\ddot{\mathrm{u}}$ & $\ddot{\mathrm{u}}$ & & $\ddot{\mathrm{u}}$ & $\ddot{\mathrm{u}}$ & $\ddot{\mathrm{u}}$ & $\ddot{\mathrm{u}}$ & $\underline{\ddot{u}}$ & $\breve{\mathrm{u}}$ & $\breve{\mathrm{u}}$ & $\underline{\ddot{0}}$ \\
\hline *lüškalta- 'shake, swing' & & & $\ddot{\mathrm{u}}$ & & & & $\ddot{\mathrm{u}}$ & $\breve{\mathrm{u}}$ & & $\breve{\mathrm{u}}$ & \\
\hline *lüšte- 'milk' & $\ddot{\mathrm{u}}$ & $\ddot{\mathrm{u}}$ & $\ddot{\mathrm{u}}$ & $\ddot{\mathrm{u}}$ & $\ddot{\mathrm{u}}$ & $\ddot{\mathrm{u}}$ & $\ddot{\mathrm{u}}$ & & $\breve{\mathrm{u}}$ & & ә \\
\hline *mündər 'far' & $\ddot{\mathrm{u}}$ & $\ddot{\mathrm{u}}$ & $\ddot{\mathrm{u}}$ & $\ddot{\mathrm{u}}$ & $\ddot{\mathrm{u}}$ & $\ddot{\mathrm{u}}$ & $\ddot{\mathrm{u}}$ & $\underline{\ddot{u}}$ & $\breve{\mathrm{u}}$ & $\breve{\mathrm{u}}$ & ә \\
\hline *müškər 'belly' & $\ddot{\mathrm{u}}$ & $\ddot{\mathrm{u}}$ & $\ddot{\mathrm{u}}$ & $\ddot{\mathrm{u}}$ & $\ddot{\mathrm{u}}$ & $\ddot{\mathrm{u}}$ & $\ddot{\mathrm{u}}$ & $\breve{\mathrm{u}}$ & & $\breve{\mathrm{u}}, \underline{\underline{\mathrm{a}}}$ & ә \\
\hline *nüštala- 'blow one's nose' & $\ddot{\mathrm{u}}$ & $\ddot{\mathrm{u}}$ & $\ddot{\mathrm{u}}$ & $\ddot{\mathrm{u}}$ & $\ddot{\mathrm{u}}$ & $\ddot{\mathrm{u}}$ & $\ddot{\mathrm{u}}$ & $\breve{\mathrm{u}}$ & $\underline{\ddot{u}}$ & $\underline{\breve{o}}$ & $\underline{\hat{\theta}}$ \\
\hline *nǔškə 'blunt' & $\ddot{\mathrm{u}}$ & $\ddot{\mathrm{u}}$ & & $\ddot{\mathrm{u}}$ & $\ddot{\mathrm{u}}$ & $\ddot{\mathrm{u}}$ & $\ddot{\mathrm{u}}$ & $\underline{\ddot{u}}$ & $\breve{\mathrm{u}}$ & $\ddot{\mathrm{u}}$ & ә \\
\hline *nüža- 'scrape' & $\ddot{\mathrm{u}}$ & $\ddot{\mathrm{u}}$ & & $\ddot{\mathrm{u}}$ & $\ddot{\mathrm{u}}$ & $\ddot{\mathrm{u}}$ & $\ddot{\mathrm{u}}$ & $\breve{\mathrm{u}}$ & $\breve{\mathrm{u}}$ & $\breve{\mathrm{u}}$ & ә \\
\hline *püčka- 'cut off' & $\ddot{\mathrm{u}}$ & $\ddot{\mathrm{u}}$ & $\ddot{\mathrm{u}}$ & $\ddot{\mathrm{u}}$ & $\ddot{\mathrm{u}}$ & ü & $\ddot{\mathrm{u}}$ & $\breve{\mathrm{u}}$ & $\breve{\mathrm{u}}$ & $\breve{\mathrm{u}}$ & o \\
\hline *pŭnčə 'pine' & $\ddot{\mathrm{u}}$ & $\ddot{\mathrm{u}}$ & $\ddot{\mathrm{u}}$ & $\ddot{\mathrm{u}}$ & $\ddot{\mathrm{u}}$ & $\ddot{\mathrm{u}}$ & $\ddot{\mathrm{u}}$ & $\underline{\ddot{u}}$ & $\breve{\mathrm{u}}$ & $\breve{\mathrm{u}}$ & \\
\hline *pürde- 'cover with a cloth' & $\ddot{\mathrm{u}}$ & & & & $\ddot{\mathrm{u}}$ & $\ddot{\mathrm{u}}$ & $\ddot{\mathrm{u}}$ & $\underline{\ddot{u}}$ & $\breve{\mathrm{u}}$ & $\underline{\ddot{u}}$ & ә \\
\hline *rŭće- 'shake' & $\ddot{\mathrm{u}}$ & $\underline{\mathbf{u}}$ & $\underline{\mathbf{u}}$ & $\ddot{\mathrm{u}}$ & $\ddot{\mathrm{u}}$ & $\ddot{\mathrm{u}}$ & $\ddot{\mathrm{u}}$ & $\breve{\mathrm{u}}$ & $\breve{\mathrm{u}}$ & $\breve{\mathrm{u}}$ & ә \\
\hline *rŭdana- 'rust' & $\ddot{\mathrm{u}}$ & $\ddot{\mathrm{u}}$ & $\ddot{\mathrm{u}}$ & $\ddot{\mathrm{u}}$ & $\ddot{\mathrm{u}}$ & $\ddot{\mathrm{u}}$ & $\ddot{\mathrm{u}}$ & $\breve{\mathrm{u}}$ & $\breve{\mathrm{u}}$ & $\breve{\mathrm{u}}$ & ә \\
\hline *rŭde- 'pick, pluck' & $\ddot{\mathrm{u}}$ & $\ddot{\mathrm{u}}$ & $\ddot{\mathrm{u}}$ & $\ddot{\mathrm{u}}$ & $\ddot{\mathrm{u}}$ & $\ddot{\mathrm{u}}$ & $\ddot{\mathrm{u}}$ & $\breve{\mathrm{u}}$ & $\breve{\mathrm{u}}$ & $\breve{\mathrm{u}}$ & ә \\
\hline *rŭdə 'core' & $\ddot{\mathrm{u}}$ & $\ddot{\mathrm{u}}$ & & $\ddot{\mathrm{u}}$ & $\ddot{u}$ & $\ddot{\mathrm{u}}$ & $\ddot{\mathrm{u}}$ & $\breve{\mathrm{u}}$ & $\breve{\mathrm{u}}$ & $\breve{\mathrm{u}}$ & ә \\
\hline *rŭm(b)alge- 'get dark' & $\ddot{\mathrm{u}}$ & $\ddot{\mathrm{u}}$ & $\ddot{\mathrm{u}}$ & $\ddot{\mathrm{u}}$ & $\ddot{\mathrm{u}}$ & $\ddot{\mathrm{u}}$ & & $\breve{\mathrm{u}}$ & $\breve{\mathrm{u}}$ & $\breve{\mathrm{u}}$ & ә \\
\hline *rŭpse- 'rock' & $\ddot{\mathrm{u}}$ & $\ddot{\mathrm{u}}$ & $\ddot{\mathrm{u}}$ & $\ddot{\mathrm{u}}$ & $\ddot{\mathrm{u}}$ & $\ddot{\mathrm{u}}$ & $\ddot{\mathrm{u}}$ & $\breve{\mathrm{u}}$ & $\breve{\mathrm{u}}$ & $\breve{\mathrm{u}}$ & ә \\
\hline *rŭškalta- 'quake, rumble' & & & & & $\ddot{u}$ & $\ddot{\mathrm{u}}$ & & & & & ә \\
\hline *rüškə 'gnarl' & $\ddot{\mathrm{u}}$ & & & & & $\ddot{\mathrm{u}}$ & & $\underline{\ddot{u}}$ & $\breve{\mathrm{u}}$ & $\breve{\mathrm{u}}$ & ә \\
\hline *sŭdər(n)e- 'drag' & $\ddot{\mathrm{u}}$ & $\ddot{\mathrm{u}}$ & $\ddot{\mathrm{u}}$ & $\ddot{\mathrm{u}}$ & $\ddot{\mathrm{u}}$ & $\ddot{\mathrm{u}}$ & $\ddot{\mathrm{u}}$ & $\breve{\mathrm{u}}$ & $\breve{\mathrm{u}}$ & $\breve{\mathrm{u}}$ & ә \\
\hline *sŭke- 'shove' & $\ddot{\mathrm{u}}$ & $\ddot{\mathrm{u}}$ & $\ddot{\mathrm{u}}$ & $\ddot{\mathrm{u}}$ & $\ddot{\mathrm{u}}$ & $\ddot{\mathrm{u}}$ & $\ddot{\mathrm{u}}$ & $\underline{\ddot{u}}$ & $\underline{\ddot{u}}$ & $\underline{\ddot{u}}$ & ә \\
\hline
\end{tabular}




\begin{tabular}{|c|c|c|c|c|c|c|c|c|c|c|c|}
\hline Proto-Mari *ü: & B & $\mathrm{Kr}$ & $\mathrm{Ka}$ & $\mathrm{Ki}$ & $S$ & M & MU & $\mathrm{U}$ & $\mathrm{V}$ & $\mathrm{Nw}$ & W \\
\hline *sülə 'fathom' & $\ddot{\mathrm{u}}$ & $\ddot{\mathrm{u}}$ & $\ddot{\mathrm{u}}$ & $\ddot{\mathrm{u}}$ & $\ddot{\mathrm{u}}$ & $\ddot{\mathrm{u}}$ & $\ddot{\mathrm{u}}$ & $\underline{\ddot{\mathbf{u}}}$ & $\underline{\ddot{\mathbf{u}}}$ & $\underline{\ddot{\mathbf{u}}}$ & ә \\
\hline *süm 'sense of touch' & $\ddot{\mathrm{u}}$ & & & $\ddot{\mathrm{u}}$ & $\ddot{\mathrm{u}}$ & $\ddot{\mathrm{u}}$ & & & $\breve{\mathrm{u}}$ & & ә \\
\hline *süre- 'smear' & $\ddot{\mathrm{u}}$ & $\ddot{\mathrm{u}}$ & $\ddot{\mathrm{u}}$ & $\ddot{\mathrm{u}}$ & $\ddot{\mathrm{u}}$ & $\ddot{\mathrm{u}}$ & & $\breve{\mathrm{u}}$ & $\breve{\mathrm{u}}$ & $\breve{\mathrm{u}}$ & ә \\
\hline *sürtńe- 'trip, tumble' & $\ddot{\mathrm{u}}$ & $\ddot{\mathrm{u}}$ & & $\ddot{\mathrm{u}}$ & $\ddot{\mathrm{u}}$ & $\ddot{\mathrm{u}}$ & $\ddot{\mathrm{u}}$ & & $\breve{\mathrm{u}}$ & & ә \\
\hline *śüwəće- 'shell (nuts)' & & & & & $\ddot{\mathrm{u}}$ & & & $\breve{\ddot{\mathrm{u}}}$ & $\breve{\ddot{\mathrm{u}}}$ & $\breve{\ddot{\mathrm{u}}}$ & \\
\hline *šŭćć 'soot' & $\ddot{\mathrm{u}}$ & $\ddot{\mathrm{u}}$ & $\ddot{\mathrm{u}}$ & $\ddot{\mathrm{u}}$ & $\ddot{\mathrm{u}}$ & $\ddot{\mathrm{u}}$ & $\ddot{\mathrm{u}}$ & $\underline{\mathrm{u}}$ & $\breve{\mathrm{u}}$ & $\underline{\hat{\mathbf{z}}}$ & $\underline{\hat{\mathrm{o}}}$ \\
\hline ‘šüdəkšs ‘barrel hoop' & $\ddot{\mathrm{u}}$ & $\ddot{\mathrm{u}}$ & $\ddot{\mathrm{u}}$ & $\ddot{\mathrm{u}}$ & $\ddot{\mathrm{u}}$ & $\ddot{\mathrm{u}}$ & $\underline{\hat{\mathbf{\theta}}}$ & $\breve{\mathrm{u}}$ & $\underline{\mathrm{z}}$ & $\underline{\mathrm{\theta}}$ & \\
\hline *šŭdər 'spindle' & $\ddot{\mathrm{u}}$ & $\ddot{\mathrm{u}}$ & $\ddot{\mathrm{u}}$ & $\ddot{\mathrm{u}}$ & $\ddot{\mathrm{u}}$ & $\ddot{\mathrm{u}}$ & $\ddot{\mathrm{u}}$ & $\breve{\mathrm{u}}$ & $\breve{\mathrm{u}}$ & $\breve{\mathrm{u}}, \underline{\mathrm{z}}$ & ә \\
\hline *šŭgə 'bark beetle' & & $\ddot{\mathrm{u}}$ & & $\ddot{\mathrm{u}}$ & & & $\ddot{\mathrm{u}}$ & $\breve{\mathrm{u}}$ & & $\breve{\mathrm{u}}$ & ә \\
\hline *šüm 'heart' & $\ddot{\mathrm{u}}$ & $\ddot{\mathrm{u}}$ & $\ddot{\mathrm{u}}$ & $\ddot{\mathrm{u}}$ & $\ddot{\mathrm{u}}$ & $\ddot{\mathrm{u}}$ & $\ddot{\mathrm{u}}$ & $\breve{\mathrm{u}}$ & $\breve{\mathrm{u}}$ & $\breve{\mathrm{u}}$ & $\underline{\mathrm{u}}$ \\
\hline *šŭm 'scale' & $\ddot{\mathrm{u}}$ & $\ddot{\mathrm{u}}$ & $\ddot{\mathrm{u}}$ & $\ddot{\mathrm{u}}$ & $\ddot{\mathrm{u}}$ & $\ddot{\mathrm{u}}, \underline{\mathrm{o}}$ & $\ddot{\mathrm{u}}$ & $\breve{\mathrm{u}}$ & $\underline{\ddot{0}}$ & $\breve{\mathrm{u}}$ & $\underline{\mathrm{u}}$ \\
\hline *šürrgə 'cheeks, face' & $\ddot{\mathrm{u}}$ & $\ddot{\mathrm{u}}$ & $\ddot{\mathrm{u}}$ & $\ddot{\mathrm{u}}$ & $\ddot{\mathrm{u}}$ & $\ddot{\mathrm{u}}$ & $\ddot{\mathrm{u}}$ & $\breve{\mathrm{u}}$ & $\breve{\mathrm{u}}$ & $\breve{\mathrm{u}}$ & ə \\
\hline *šürgə 'forest' & & & & $\ddot{\mathrm{u}}$ & & $\ddot{\mathrm{u}}$ & & & $\breve{\mathrm{u}}$ & & ә \\
\hline *šürtə 'yarn' & $\ddot{\mathrm{u}}$ & $\ddot{\mathrm{u}}$ & $\ddot{\mathrm{u}}$ & $\ddot{\mathrm{u}}$ & $\ddot{\mathrm{u}}$ & $\ddot{\mathrm{u}}$ & $\ddot{\mathrm{u}}$ & $\underline{\ddot{\mathbf{u}}}$ & $\breve{\mathrm{u}}$ & $\breve{\mathrm{u}}$ & ә \\
\hline *šüška- 'stuff' & $\ddot{\mathrm{u}}$ & $\ddot{\mathrm{u}}$ & $\ddot{\mathrm{u}}$ & $\ddot{\mathrm{u}}$ & $\ddot{\mathrm{u}}$ & $\ddot{\mathrm{u}}$ & & $\breve{\ddot{\mathrm{u}}}$ & $\breve{\mathrm{u}}$ & $\breve{\mathrm{u}}$ & ә \\
\hline *šŭštə 'leather' & $\ddot{\mathrm{u}}$ & $\ddot{\mathrm{u}}$ & $\ddot{\mathrm{u}}$ & $\ddot{\mathrm{u}}$ & $\ddot{\mathrm{u}}$ & $\ddot{\mathrm{u}}$ & $\ddot{\mathrm{u}}$ & $\underline{\ddot{u}}$ & $\breve{\mathrm{u}}$ & $\underline{\mathbf{\theta}}$ & ә \\
\hline *šŭwala- 'spit' & $\ddot{\mathrm{u}}$ & $\ddot{\mathrm{u}}$ & $\ddot{\mathrm{u}}$ & $\ddot{\mathrm{u}}$ & $\ddot{\mathrm{u}}$ & $\ddot{\mathrm{u}}$ & $\ddot{\mathrm{u}}$ & $\breve{\mathrm{u}}$ & $\breve{\mathrm{u}}$ & $\breve{\mathrm{u}}$ & ә \\
\hline *tün 'base' & $\ddot{\mathrm{u}}$ & $\ddot{\mathrm{u}}, \underline{\mathrm{z}}$ & $\ddot{\mathrm{u}}$ & $\ddot{\mathrm{u}}$ & $\ddot{\mathrm{u}}$ & $\ddot{\mathrm{u}}$ & $\ddot{\mathrm{u}}$ & $\breve{\mathrm{u}}, \underline{\mathrm{u}}$ & $\breve{\mathrm{u}}$ & $\breve{\mathrm{u}}$ & ә \\
\hline *tür 'edge; blade' & $\ddot{\mathrm{u}}$ & $\ddot{\mathrm{u}}$ & $\ddot{\mathrm{u}}$ & $\ddot{\mathrm{u}}$ & $\ddot{\mathrm{u}}$ & $\ddot{\mathrm{u}}$ & $\ddot{\mathrm{u}}$ & $\breve{\mathrm{u}}$ & $\breve{\ddot{u}}$ & $\breve{\mathrm{u}}$ & ә \\
\hline *türeda- 'harvest' & $\ddot{\mathrm{u}}$ & $\ddot{\mathrm{u}}$ & $\ddot{\mathrm{u}}$ & $\ddot{\mathrm{u}}$ & $\ddot{\mathrm{u}}$ & $\ddot{\mathrm{u}}$ & & $\breve{\mathrm{u}}, \underline{\emptyset}$ & $\breve{\mathrm{u}}$ & $\underline{\text { o }}$ & ә \\
\hline *türəś 'full' & $\ddot{\mathrm{u}}$ & $\ddot{\mathrm{u}}$ & & $\ddot{\mathrm{u}}$ & $\ddot{\mathrm{u}}$ & $\ddot{\mathrm{u}}$ & $\ddot{\mathrm{u}}$ & $\breve{\mathrm{u}}$ & $\breve{\mathrm{u}}$ & & ә \\
\hline *türwo ‘lip' & $\ddot{\mathrm{u}}$ & $\ddot{\mathrm{u}}$ & $\ddot{\mathrm{u}}$ & $\ddot{\mathrm{u}}$ & $\ddot{\mathrm{u}}$ & $\ddot{\mathrm{u}}$ & $\ddot{\mathrm{u}}$ & $\breve{\mathrm{u}}$ & $\breve{\mathrm{u}}$ & $\breve{\mathrm{u}}$ & ә \\
\hline *türwəńća- 'sneeze' & $\ddot{\mathrm{u}}$ & $\ddot{\mathrm{u}}$ & $\ddot{\mathrm{u}}$ & $\ddot{\mathrm{u}}$ & $\ddot{\mathrm{u}}$ & $\ddot{\mathrm{u}}$ & $\ddot{\mathrm{u}}$ & $\breve{\mathrm{u}}$ & $\breve{\mathrm{u}}$ & $\breve{\mathrm{u}}$ & ә \\
\hline *tŭška 'group (of people), herd' & $\ddot{\mathrm{u}}$ & & $\ddot{\mathrm{u}}$ & $\ddot{\mathrm{u}}$ & & $\ddot{\mathrm{u}}$ & $\ddot{\mathrm{u}}$ & $\underline{\ddot{u}}$ & $\breve{\mathrm{u}}$ & & ә \\
\hline *tüwot 'entirely' & & $\ddot{\mathrm{u}}$ & & $\ddot{\mathrm{u}}$ & $\ddot{\mathrm{u}}$ & $\ddot{\mathrm{u}}$ & & $\breve{\mathrm{u}}$ & & & ә \\
\hline *tüžem 'thousand' & $\ddot{\mathrm{u}}$ & $\ddot{\mathrm{u}}$ & $\ddot{\mathrm{u}}$ & $\ddot{\mathrm{u}}$ & $\ddot{\mathrm{u}}$ & $\ddot{\mathrm{u}}$ & $\ddot{\mathrm{u}}$ & $\breve{\mathrm{u}}$ & $\breve{\mathrm{u}}$ & $\breve{\mathrm{u}}$ & ә \\
\hline *üdərr 'girl, daughter' & $\ddot{\mathrm{u}}$ & $\ddot{\mathrm{u}}$ & $\ddot{\mathrm{u}}$ & $\ddot{\mathrm{u}}$ & $\ddot{\mathrm{u}}$ & $\ddot{\mathrm{u}}$ & $\ddot{\mathrm{u}}$ & $\breve{\mathrm{u}}$ & $\breve{\mathrm{u}}$ & $\breve{\mathrm{u}}$ & ә \\
\hline *üúsərt 'stubborn' & $\ddot{\mathrm{u}}$ & & & & $\ddot{\mathrm{u}}$ & $\ddot{\mathrm{u}}$ & $\ddot{\mathrm{u}}$ & $\ddot{\mathrm{u}}, \underline{\mathrm{u}}$ & & $\breve{\mathrm{u}}$ & \\
\hline *üštə 'belt' & $\ddot{\mathrm{u}}$ & $\ddot{\mathrm{u}}$ & $\ddot{\mathrm{u}}$ & $\ddot{\mathrm{u}}$ & $\ddot{\mathrm{u}}$ & $\ddot{\mathrm{u}}$ & $\ddot{\mathrm{u}}$ & $\underline{\ddot{\mathbf{u}}}$ & $\underline{\ddot{\mathbf{u}}}$ & $\underline{\ddot{\mathbf{u}}}$ & ә \\
\hline *üžgar 'thing' & $\ddot{\mathrm{u}}$ & $\ddot{\mathrm{u}}$ & & & $\ddot{\mathrm{u}}$ & $\ddot{\mathrm{u}}, \underline{\mathbf{u}}$ & $\ddot{\mathrm{u}}$ & $\breve{\mathrm{u}}$ & $\underline{\mathrm{z}}$ & $\breve{\mathrm{u}}, \underline{\mathrm{z}}$ & ә \\
\hline *ǚ̌zwor 'common swift' & $\ddot{\mathrm{u}}$ & $\ddot{\mathrm{u}}$ & & $\ddot{\mathrm{u}}$ & & $\ddot{\mathrm{u}}$ & & $\breve{\mathrm{u}}$ & & & ә \\
\hline *wüčə 'cut, notch' & & $\ddot{\mathrm{u}}$ & & $\ddot{\mathrm{u}}$ & & & $\ddot{\mathrm{u}}$ & $\underline{\ddot{\mathbf{u}}}$ & & & ә \\
\hline *wül- 'on, up, over' & & & & & & & $\ddot{\mathrm{u}}$ & $\breve{\mathrm{u}}$ & & $\breve{\mathrm{u}}, \underline{\mathrm{z}}$ & ә \\
\hline *wül/llə 'mare' & $\ddot{\mathrm{u}}$ & $\ddot{\mathrm{u}}$ & $\ddot{\mathrm{u}}$ & $\ddot{\mathrm{u}}$ & $\ddot{\mathrm{u}}$ & $\ddot{\mathrm{u}}$ & $\ddot{\mathrm{u}}$ & $\breve{\ddot{\mathrm{u}}}$ & $\breve{\mathrm{u}}$ & $\breve{\mathrm{u}}$ & ә \\
\hline *wür 'blood' & $\ddot{\mathrm{u}}$ & $\ddot{\mathrm{u}}$ & $\ddot{\mathrm{u}}$ & $\ddot{\mathrm{u}}$ & $\ddot{\mathrm{u}}$ & $\ddot{\mathrm{u}}$ & $\ddot{\mathrm{u}}$ & $\breve{\mathrm{u}}$ & $\breve{\ddot{\mathrm{u}}}$ & $\breve{\ddot{\mathrm{u}}}$ & ә \\
\hline *würgeńə ‘copper' & $\ddot{\mathrm{u}}$ & $\ddot{\mathrm{u}}$ & & $\ddot{\mathrm{u}}$ & $\ddot{\mathrm{u}}$ & $\ddot{\mathrm{u}}$ & $\ddot{\mathrm{u}}$ & $\breve{\mathrm{u}}$ & $\breve{\mathrm{u}}$ & $\breve{\mathrm{u}}$ & ә \\
\hline *wüt 'water' & $\ddot{\mathrm{u}}$ & $\ddot{\mathrm{u}}$ & $\ddot{\mathrm{u}}$ & $\ddot{\mathrm{u}}$ & $\ddot{\mathrm{u}}$ & $\ddot{\mathrm{u}}$ & $\ddot{\mathrm{u}}$ & $\breve{\mathrm{u}}$ & $\breve{\mathrm{u}}$ & $\breve{\mathrm{u}}$ & ә \\
\hline *wütel’ə 'snipe' & $\ddot{\mathrm{u}}$ & & & & $\ddot{\mathrm{u}}$ & $\ddot{\mathrm{u}}$ & $\ddot{\mathrm{u}}$ & $\ddot{\mathrm{u}}, \underline{\mathrm{u}}$ & & $\breve{\mathrm{u}}$ & ә \\
\hline
\end{tabular}


Appendix B. Uralic etymologies of Mari words with close full and reduced vowels

\section{PMari ${ }^{*} \breve{i}<$ PU *e}

- E ilem, Ki ilem, V ălem, U Nw W alem 'I live' < PMari *̌le- < PU *elä- (UEW: 73; HPUL: 536)

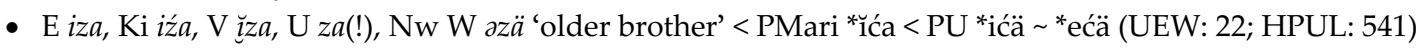

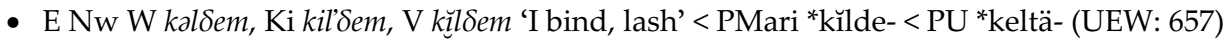

- E U laštaš, Ki lišstaš, V lǔštaš, Nw laštäš, W laštä̌s alaštäš (!) 'leaf' < PMari *lištaš < PU *lešti (UEW: 690)

- E U Nw W nal, Ki nil 'four' < PMari *nĭl < PU *neljä (UEW: 315-316; HPUL: 547)

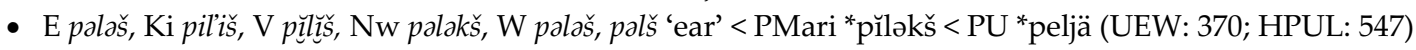

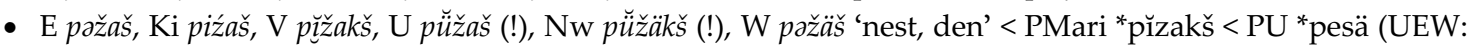
375; HPUL: 539)

- E Nw rawaž, Ki riwiž, U rüzwüž (!), W rawaž arwaž 'fox' < PMari *rĭwəž < PU *repäś (UEW: 423-424; HPUL: 553)

- E U Nw šolaž 'small of the back' < PMari * š̌ləž < PU *śelkä (UEW: 772)

PMari ${ }^{*}{ }^{-}<$PU $*_{\mathbf{i}}$

- E iza, Ki iźa, V ̆za, U za (!), Nw W azä 'older brother' < PMari *ića < PU *ićä *ećä (UEW: 22; HPUL: 541)

- E kac̆ək, Ka kaç̌ək, U kacək, Nw kacä lŏm, W kəčă 'newly fallen fine snow' < PMari *kičək, *Kičäa < PU *kičV(SSA s.v. kide)

- E karem, krem, Ki kirem, V krem, Nw karem 'I hit, forge, hammer, thresh' < PMari *kŭre- < PU *kirä- (UEW: 666; HPUL: 552)

- E Nw W kaškem, Ki kiškem, V kĭ̌̌kem 'I throw; I pour' < PMari *kǔške- < PU *kiśki- (HPUL: 552; cf. UEW: 667)

- Ki jičke-, W jačke- 'pick, pluck, pull' < PMari *jučke- < PU *níčkä- (Aikio, forthcoming). - The change *ńí- > *jī- has a parallel in PMari *jĭlmə 'tongue' < PU *nälmä (see below). Note that E Nw W nal, Ki nil 'four' (< PMari *nil) is not a counterexample to this change, because this numeral originally had ${ }^{*} \mathrm{n}$ - instead of *ń- (PU *neljä). The unpalatalized nasal is also preserved in Hungarian négy and many Saami languages (e.g., Ume Saami nelja, Inari Saami nelji). The initial ń- of some cognates (e.g., Komi ńol, East Khanty ńĕla, North Mansi ńila) seems to have developed due the assimilatory influence of word-internal ${ }^{*} \mathrm{j}-$.

- E Nw pazem, Ki piżem 'I hold on, cling to' < PMari *pǔće- < PU *pitä- (Aikio, forthcoming)

- E mań, maj, maja, Ki miń, U mań, mańe, V mŭń, Nw mŭń, W mińa, mańa 'I' < PMari *mǔń < PU *minä (cf. UEW: 294)

- E šiñča, Nw š̌ncä, W šncä, sancä 'eye’ < PMari *šñ-ćä < PU *śilmä (UEW: 479; HPUL: 540)

- E taja, taj, Ki tiń, U tańa, tań, V tr̆j, Nw tań, tı̌ń, W tańa, tǔn 'you (sg.)' < PMari *tíń < PU *tinä (cf. UEW: 539)

\section{PMari ${ }^{*} \breve{\mathbf{i}}<\mathrm{PU} * \ddot{\mathbf{u}}$}

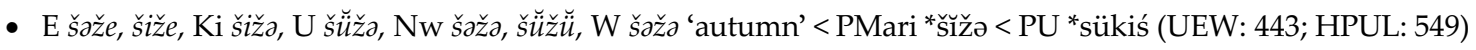

- E kačkem, kič́kem, Ki kič́kem, V kı̆skem, U Nw W kackem 'I harness' < PMari *kićke- < PU *kütki- (UEW: 903)

- E kalme, Ki kilme, V kỉlme, Nw W kalma 'frozen' < PMari *kĭlmə < PU *külmä (UEW: 663; HPUL: 552)

- E Nw W kańer, Ki kińer, V kŭner 'ell' < PMari *kǔńer < PU *künärä (UEW: 158-159; HPUL: 544)

- E ńokta-, Nw ńiktä-, W ńaktä- 'skin' < PMari *ńikta- < PU *nüktä- (UEW: 715)

- E šazal’e, Ki šizil’’, U Nw šajal’’, W šayal' 'wart' < PMari *šĭgəl’ə < PU *śüklä (UEW: 36-37; HPUL: 549)

\section{PMari *jī- < PU *jä-, *nää-}

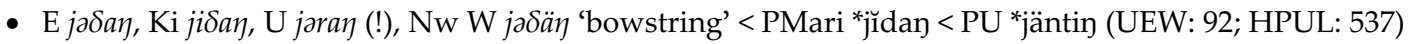

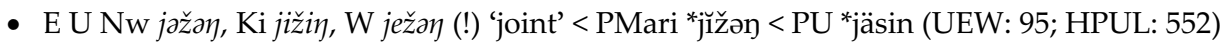

- E jama, Ki jima '(a body part) grows numb; (an eye) goes blind', U jama, Nw W jamä 'hides oneself; (a tooth) aches severely; (an eye) goes blind'< PMari *jĭme- 'go numb' $<$ PU *jämä- (Aikio, forthcoming)

- E V jalme, Ki jülmö (!), Nw jĭlma, W jülma, jalma ‘tongue, language’ < PMari *jĭlmə < PU *nälmä (UEW: 313; HPUL: 546).

\section{PMari ${ }^{*} \mathbf{i}<$ PU *ä}

- E ime, Nw ima, W im 'needle' < PMari *imə < PU *äjmä (UEW: 22; HPUL: 536)

- W kiže- 'feel cold' < PMari *kiže- < PU *känśV- (Aikio 2002: 21; cf. UEW: 648, HPUL: 552)

- E kit, kat (!), Nw W kit 'hand' < PMari *kit < PU *käti (UEW: 140; HPUL: 545) 
- E liš-, laš- (!), Nw W liš- 'near' < PMari *liš- < PU *läsi- (UEW: 687)

- E piste, pište, Nw W pista 'linden' < PMari *pistə < PU *päkšnä (UEW: 726)

- E šište, Nw W šišta 'woodpecker' < PMari *šištə < PU *šäśnä (UEW: 772; HPUL: 554)

- E tič, U Nw tic, W cic 'full' < PMari *tić < PU *täwdi (cf. UEW: 518; HPUL: 550; Aikio 2002: 31-34)

- E V lewa, Ki l'ewa, U liwa, Nw W liwä 'it becomes warm' < PMari *liwe- < PU *lämpi- (UEW: 685; Aikio, forthcoming)

- E V šen, MU U Nw W šin 'tinder' < PMari *šin < PU *śänä (UEW: 494-495; HPUL: 548)

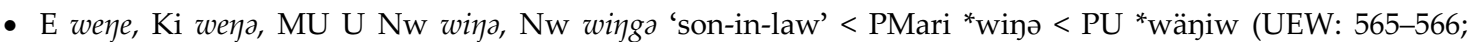
HPUL: 541)

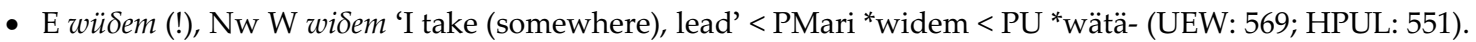
- Traditionally reconstructed as *wetä-, but both Moksha Mordvin vät’- 'lead, guide' and Hungarian vezet 'leads, guides' point to PU *ä instead of *e; the vocalism of Finnish vetää 'pulls' is irregular.

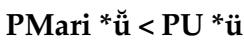

- E künčem, (Ka Kr) künç̌em, Nw küncem 'I dig' < PMari *künče- < PU *künčä- (UEW: 663-664)

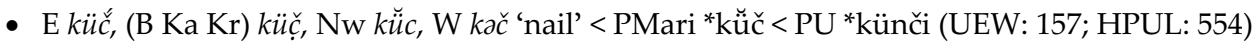

- E küžzö, Nw küžðü̈, W kəžja 'thick, fat, stout' < PMari *küžgə < PU *küsä (UEW: 161; HPUL: 544)

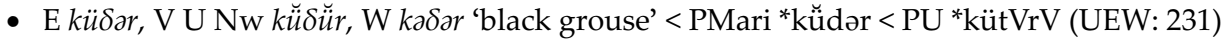

- E šülö, Nw šülü (!), W šal 'fathom' < PMari *sülə < PU *süli (UEW: 444; HPUL: 540)

- E šüškam, Nw šŭ̌̌šäm, W šəškäm 'I cram, pack' < PMari *šŭška- < PU *süskä- (UEW: 768)

- E šüwal, Nw šŭwwül, W šawal, šawal' 'spit' < PMari *šŭwəl < PU *śülki (UEW: 479-480; HPUL: 549)

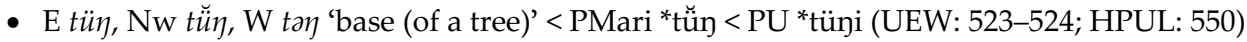

- U wü̆l-, Nw wü̆l-, wal-, W wal- 'on' < PMari *wül- < PU *wüli- (UEW: 573-574; cf. HPUL: 536)

\section{PMari * $\breve{\mathbf{u}}<$ PU *i}

- E lüm, Nw lü̈m, W lam 'name' < PMari *lüm < PU *nimi (UEW: 305; HPUL: 538)

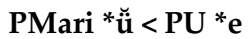

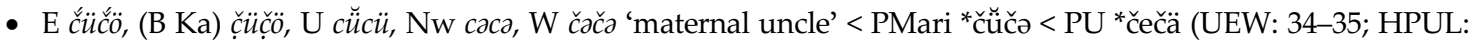
536)

- E kür, Nw kürr, W kar 'bast' < PMari *kür < PU *keri (UEW: 148-149; HPUL: 543)

- E pünćčo, (B Ka Kr) pünç̣ö, Nw pü̈ncü 'pine' < PMari *pünčə < PU *pe(n)čä (UEW: 727; HPUL: 553)

- E tür, Nw t $\breve{u r} r$, W tar 'blade; edge; shore' < PMari *tür < PU *terä (cf. UEW: 522, 795)

- E wür, Nw würr, W war 'blood' < PMari *wür < PU *weri (UEW: 576; HPUL: 551)

- E wüt, Nw wü̆t, W wat 'water' < PMari *wüt < PU *weti (UEW: 570-571; HPUL: 541)

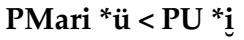

- E W üp 'hair on the head' < PMari *üp < PU *ipti (UEW: 14-15; HPUL: 536)

- E ülö-, W üla- 'under-' < PMari *ülə- < PU *ila (UEW: 6; HPUL: 536)

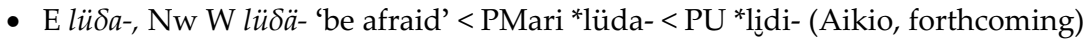

- E W šüm 'scale' < PMari *šüm < PU *śsimi (UEW: 476; 549)

- E šün, šön, Ki śün, W šün 'vein, sinew' < PMari *sün < PU *sini (UEW: 441; HPUL: 548)

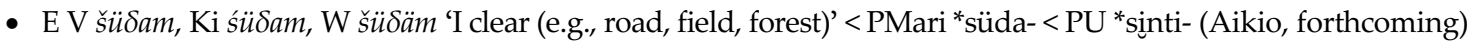

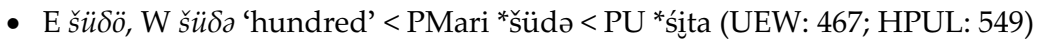

- M nöla pikš 'arrow with a bone head' < PMari *nülə < PU *ńili 'arrow' (UEW: 317; HPUL: 539)

- E W mör 'strawberry' < PU *mirja 'berry' (UEW: 264-265)

- E nörö, W nöra 'flexible, pliable' < PMari *nürə < PU *ńíri (Aikio 2012: 234)

- E nörrö, W nörra 'cartilage' < PMari *nürgə < PU *níirki (UEW: 317; HPUL: 546)

\section{PMari * $\ddot{\mathbf{u}}<$ PU *ä}

- E Nw jükšem, W ükšem 'I get cold' < PMari *jükše- < PU *jäkši- (UEW: 90-91)

- E Nw W pükš 'nut' < PMari *pükš < PU *päški (UEW: 726-727; HPUL 553)

- E šükšö, Nw W šükša 'rag; worn-out, bad, unsuitable; rotten' < PU *säksä (Aikio, forthcoming) 


\section{PMari * $\breve{\mathbf{u}}<$ PU *u}

- E jumo, Nw jŏmo, W jâmâ 'god; heaven' < PMari *jŭmə < PU *juma (UEW: 638)

- E kum, V U kŭm, Nw kŏm, W kâm 'three' < PMari *kŭm < PU *kolmi *kulmi (UEW: 174; HPUL: 543)

- E kumək, V U kŭmuk, Nw kŏmok, W kâmâk 'upside down' < PMari *kŭmək < PU *kuma- (UEW: 201-202; HPUL: 537)

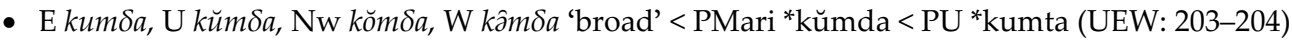

- M kužam, V U kŭžam, Nw kŏžam, W kâžam 'I urinate' < PMari *kŭža- < PU *kunśi- (UEW: 210; HPUL: 537)

- E kuwal, U kŭwul, Nw kŏwol, W kâwâl 'blister' < PMari *kŭwəl < PU *kupla (UEW: 212-213)

- E kurmazak, W kârmâzak 'Eurasian woodcock' < PMari *kŭrməćak < PU *kurmićća (UEW: 676-677). - This etymology is not accepted in SSA (s.v. kurppa), but the correspondence between Fi kurmitsa 'Eurasian woodcock' and PMari *kŭrməć- is fully regular.

- E kurək, U kŭruk, Nw kŏrok, W kârôk 'hill, mountain' < PMari *kŭrək < PU *kuri (UEW: 677)

- E kutko, V kŭtko, Nw kŏtko, W kâtkâ 'ant' < PMari *kŭtkə < PU *kutki (UEW: 678; HPUL: 552)

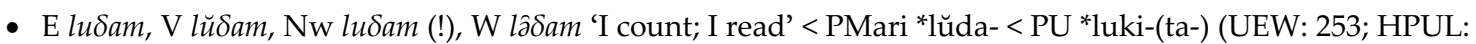
545)

- E lum, V U lŭm, Nw lŏm, W làm 'snow' < PMari *lŭm < PU *lumi (UEW: 253; HPUL: 538)

- E šińčam lumem, W sancäm lâmem 'I bewitch, cast a spell on' (šińčam, sancäm ACC 'eye') < PMari *lŭme- < PU *lumV- (UEW: 694)

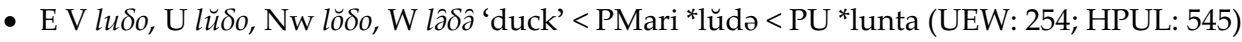

- E lupš, Ki luфš, V U lŭpš, Nw lŏpš, W lâpš ‘dew’ < PMari *lŭpš < PU *lupsa (UEW: 261; HPUL: 538)

- E muč-, V mŭč-, mŭśs-, Nw mŏc-, mac-, W mâč- 'end' (in compounds) < PMari *mŭč- < PU *muča (UEW: 283)

- E muno, M muna, V U mŭno, Nw mŏno, W mânâ 'egg; testicle' < PMari *mŭnə < PU *muna (UEW: 285; HPUL: 538)

- E nužem, U nŭžem 'I scrub (my skin); I rub off, scrape off' < PMari *nŭže- < PU *nusi- (UEW: 309)

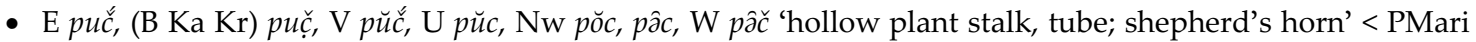
*pŭč < PU *pučki (UEW: 397; HPUL: 539)

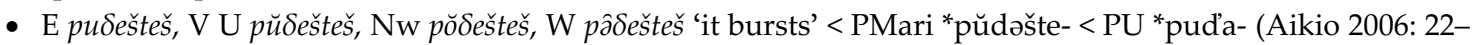
23)

- E pun, V U pŭn, Nw pŏn, W pân 'body hair, animal hair, down' < PMari *pŭn < PU *puna (UEW: 402; HPUL: 547)

- E punem, V U pŭnem, Nw pŏnem, W pânem 'I braid, plait, twine, twist' < PMari *pŭne- < PU *puna- (UEW: 402-403; HPUL: 539)

- E puram, V U pŭram, Nw pŏram, W pâram 'I chew, bite' < PMari *pŭra- < PU *puri- (UEW: 405; HPUL: 539)

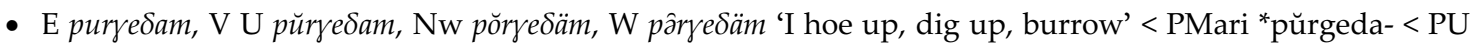
*purka- (UEW: 741)

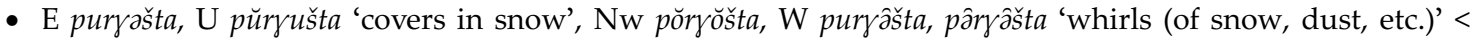
PMari *pŭrgəšte- (UEW: 406; HPUL: 547)

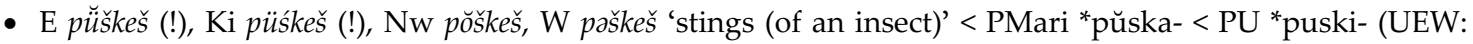
408; HPUL: 547)

- E šula, V U šŭla, Nw šŏla, W šâla 'it melts' < PMari *sŭla- < PU *sula- (UEW: 450-541; HPUL: 548)

- E šurem, V U šŭrem, Nw šŏrem, W šârem 'I pound, crush, trample; I prick (with a pin), thrust (with a knife)' $<$ PMari *šŭre- < PU *śurwV- (UEW: 491)

- W tâktâ 'boat rib' < PMari *tŭktə < PU *tuktV (UEW: 534; HPUL: 550)

- E tul, V U tŭl, Nw tŏl, tal, W tâl 'fire' < PMari *tŭl < PU *tuli (UEW: 535; HPUL: 540)

- E tunemam, V tüńemam, U tünemam (!), Nw tŏmejäm, W tâmeńäm 'I practice, learn' < PMari *tŭnema- < PU *tuni- (UEW: 537; HPUL: 550)

PMari * $\breve{\mathbf{u}}<\mathbf{P U} * \mathbf{i}$ (in disharmonic roots)

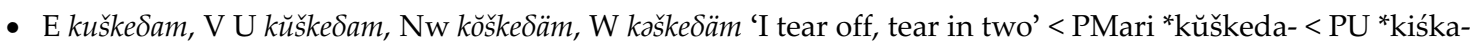
(Aikio, forthcoming; cf. HPUL: 552)

- E užar, V U ǔžar, Nw ǒžar, W azžar, žar 'green' < PMari *ǔžar < PU *wiša(-ra) (UEW: 823; HPUL: 554) 
PMari * $\breve{\mathbf{u}}<\mathbf{P U}$ *o (adjacent to labial consonants)

- E kum, V U kŭm, Nw kŏm, W kâm 'three' < PMari *kŭm < PU *kolmi *kulmi (UEW: 174; HPUL: 543)

- E kuməž, U kŭmuž, Nw kŏmož, W kâməž 'birch-bark' < PMari *kŭməž < PU *kolmis (Aikio, forthcoming)

- E kuwo, V kŭwo 'husk' < PMari *kŭwə < PU *kopa (UEW: 180; HPUL: 537)

- E kuwalćo, U kŭwŭlzo ‘wood grouse hen' < PMari *kŭwəlćə < PU *koppala (UEW: 181)

- E kupa, V U kŭpa, Nw kŏpa, W kâpa 'gets moldy' < PMari *kŭpe- < PU *koppi- (UEW: 680)

- E muškam, V mŭškam, Nw mǒškam, W mâškam 'I wash' < PMari *mŭška- < PU *mośki- (UEW: 289; HPUL: 538)

- E šumam, U šŭmam, Nw šŏmam, W šâmam 'I get tired, languish' < PMari *šŭma- < PU *śoma- (Aikio, forthcoming)

- E ulam, V U ŭlam, Nw ŏlam, alam, W âlam 'I am' < PMari *ŭla- < PU *woli- (UEW: 580-581; HPUL: 551)

- E uryem, U ŭryem, Nw ŏryem, W âryem 'I sew' < PMari *ŭrge- < PU *worka- (UEW: 584-585; HPUL: 551)

- E wuč́em, (B Ka Kr) wuçem, V wŭčem, U wŭcem, Nw wŏcem, W wâčem 'I wait' < PMari *wŭče- < PU *woča(UEW: 334)

- E užalem, V U ǔžalem, Nw ǒžalem, W wâžalem 'I sell' < PMari *wŭžale- < PU *wosa (UEW: 585; HPUL: 551)

PMari *u $<$ PU *o

- E V U Nw W ukš, Ki uks 'branch' < PMari *ukš < PU *oksa (UEW: 716; HPUL: 552)

- E ukšańčam, ukšińčam, V ukššćńă, U ukšancam, Nw ukšancam, W ukšancam, uksânzam 'I vomit' < PMari *ukšənća- < PU *oksinta- (UEW: 716; HPUL: 552)

- E ur (Kr M S ur ar!), Ki V U Nw W ur 'squirrel' < PMari *ur < PU *ora (UEW: 343; HPUL: 552)

- E Ki V U Nw W wuj 'head; end; ear (of corn); tree top' < PMari *wuj < PU *ojwa (UEW: 336-337; HPUL: 536)

- E kutkəž, W kučkâž 'eagle' < PMari *kut/čkəž < PU *kočka (UEW: 668; HPUL: 552)

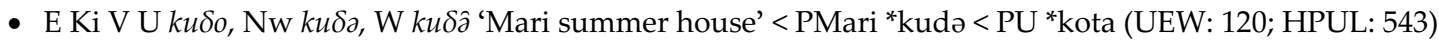

- E püčö, (B Ka) püç冖o (!), Ki pučo, V pǔče (!), U puco, Nw puca, W pučá ‘(wild) reindeer' < PMari *pučə < PU *počaw (UEW: 387-388; HPUL: 553)

- E puləš, V pŭlŭš, Nw pulǒkš, W puləš 'shoulder' < PMari *puləkš < PU *pola (UEW: 734; HPUL: 553)

- E V Nw pul-wuj, U pŭl-wuji (!), W pul-wuj, pâl-wuj (!) 'knee' < PMari *pul- < PU *polwi (UEW: 393; HPUL: 539)

- E Ki V U Nw W šukš ‘worm' < PMari *̌̌ukš < PU *soksi (UEW: 764)

- E Ki V U Nw W šuSalam 'I scold; I curse' < PMari *šudala- < PU *śod'a- (UEW: 777)

\section{Unexpected instances of full vowels}

- E Ki V U pižam, Nw W pižäm 'I grab; I get stuck' < PMari *piže- < PU *pisi- (UEW: 732)

- E wiste, Nw wišta 'spelt' < PMari * wistə < PU *wešnä (UEW: 821)

- E Nw W üpš, Ki ü申śs 'smell’ < PMari *üps < PU *ipsi (UEW: 83-84; HPUL: 536)

- E Ki V U Nw W mükš 'bee' < PMari *mükš < PU *mekši (UEW: 271; HPUL: 545)

- W juž-wat 'sweat; fluid in a blister' (<PMari *juž-; wat ‘water') < PU *jiša ‘skin' (UEW: 636-637; HPUL: 552)

А. АЙкиО. К реконструкции прамарийского вокализма.

На настоящий момент существуют две теории устройства вокалической системы в прамарийском языке, выдвинутые соответственно Э. Итконеном и Г. Берецки. В статье дается критический анализ обеих теорий, после чего автор предлагает собственную, детально аргументированную реконструкцию прамарийского вокализма первого слога. В частности, обосновывается необходимость реконструкции 11 отдельных фонем, в отличие от 13-фонемной системы Итконена и 7-фонемной системы Берецки.

Ключевые слова: уральские языки, марийский язык, праязыковая реконструкция, историческая фонетика. 
